\title{
EFEITO DA SATURAÇĀO POR BASES, RELAÇÕES Ca:Mg NO SOLO E NÍVEIS DE FÓSFORO SOBRE A PRODUÇÃO DE MATÉRIA SECA E NUTRIÇÃO MINERAL DO MILHO (Zea mays L.)
}

\section{ROGER JESUS MUÑOZ HERNÁNDEZ}

Engenheiro Agrônomo

Orientador: Prof. Dr. RONALDO IVAN SILVEIRA

Dissertação apresentada à Escola Superior de Agricultura "Luiz de Queiroz" da Universidade de São Paulo, para obtenção do título de Mestre em Agronomia. Área de Concentração: Solos e Nutrição de Plantas.

P I R A C I C A B A

Estado de São Paulo - Brasil

Setembro - 1994 
Ficha cataiggratica preparada pela secande livros da Divista de timbioteca e Uacumentacto - FuldubF

Whioz Herntinder. Roger Jeslis

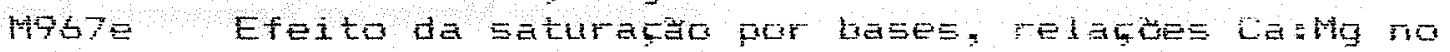
solo e nueis de tostoro sobre a producto de materia

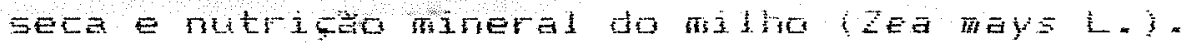

Firacicabeg 1994. 1340.

DisS. MEStre) - ESALQ

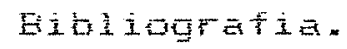

1. Nilho - Bdubacto fostatada 2. Nitho - Nutricao 3. Sola-Satiraça por base - Efeito J. Escola Stipe rior de Aoricultura luiz de Gueirot, Piracicaba 
EFEITO DA SATURAÇÃO POR BASES, RELAÇÕES Ca:Mg NO SOLO E NÍVEIS DE FÓSFORO SOBRE A PRODUÇÃo DE MATÉRIA SECA E NUTRIÇÃO MINERAL DO MILHO (Zea mays L.)

Aprovada em 03.11.1994

Comissão julgadora:

Prof. Dr Ronaldo Ivan Silveira

Prof. Dr. Antonio Enedi Boaretto

Prof. Dra. Neli Marisa Azevedo Silva
ESALQ/USP

CENA/USP

FMVZ/USP

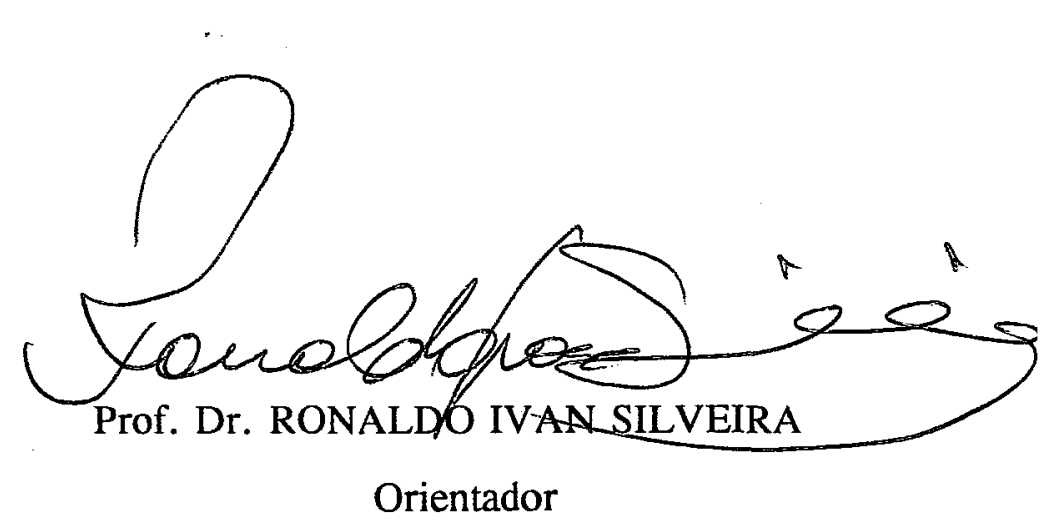


A Deus

À minha mãe, Belkis, a minha gratidão, pelo seu carinho, apoio, confiança e compreensão, que possibilitaram a conquista deste objetivo, em prol da minha formação acadêmica.

Aos meus irmãos, Leda, Francisco, Maricela, Ronald, Breda, Gioconda, Belkis, John Leopoldo, pela solidariedade, incentivo e respeito que sempre me dedicaram.

Ao meu pai, Rafael Francisco,

(in memoriam)

A todos eles, com muito amor, 


\section{AGRADECIMENTOS}

A Deus Pai todo-poderoso, toda honra, glória e louvor agora e para sempre, por sua presença durante todo o tempo, pela saúde e perseverança concedidas para mais esta realização.

À Universidade de São Paulo e ao Departamento de Ciência do Solo da Escola Superior de Agricultura "Luiz de Queiroz", Campus de Piracicaba, por ter permitido meu ingresso e a oportunidade de realização do Curso.

Ào Governo da República Federativa do Brasil, Programa de Estudantes Convênio de Pós-Graduação - PEC/PG e ao Convênio MRE/DCT-MEC/CAPES pela concessão da Bolsa de Estudo.

Ao Professor Doutor Ronaldo Ivan Silveira, pela amizade e confiança, experiente orientação durante o curso e pelas suas constantes e valiosas contribuições na realização deste trabalho.

Aos Professores Dr. Antonio Enedi Boaretto e Dra. Neli Marisa Azevedo Silva, pelas importantes sugestões que muito contribuíram para o enriquecimento deste trabalho.

Aos Professores do Curso de Solos e Nutrição de Plantas, pela amizade e contribuições nos ensinamentos transmitidos. 
Ao Professor Doutor Geraldo Victorino de França, Coordenador do Curso, pela amizade com que me distinguiu e pela especial atenção.

Às funcionárias da Seção de Pós-Graduação, pela amizade e pela atenção dispensada.

Aos meus colegas de Curso, pela amizade durante o nosso convívio.

À Ila Cardim Rêgo, pela estima, pelo apoio, pela troca de idéias e, sobretudo, pela sincera amizade demonstrada no decorrer do curso.

À Kátia Maria de Andrade Ferraz pelo auxílio na revisão e correção das referências bibliográficas consultadas e principalmente, pela sincera amizade e pela especial atenção dispensada.

À Clotilde Maria Batochio Cunha, pela digitação da Dissertação e dedicação na correção do uso da língua portuguesa e pela especial atenção.

À Da Yvonne Balbaud, Da Alzira Tuzini e José Roberto Martins pela acolhida, pelo estímulo, pela amizade sincera e por ter tornado mais agradável a minha convivência.

Aos funcionários do Departamento de Ciência do Solo, pela valiosa ajuda durante as diversas fases da pesquisa.

A todos aqueles, que de uma forma ou de outra, contribuíram para a realização deste trabalho. 


\section{SUMÁRIO}

LISTA DE QUADROS................................................ vi

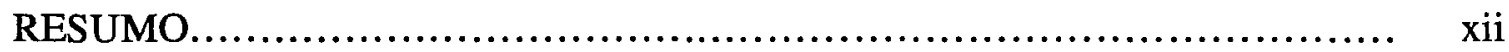

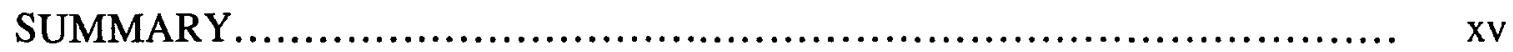

1. INTRODUÇÃO............................................................ 1

2. REVISÃO DE LITERATURA............................................

2.1. Nutrição mineral em plantas: Considerações gerais....................... 4

2.2. Dinâmica dos cátions cálcio e magnésio no solo........................... 6

2.3. Dinâmica de fósforo no solo.......................................... 12

2.4. Macronutrientes no solo e na planta................................. 15

2.4.1. Nitrogênio...................................................... 15

2.4.2. Fósforo............................................................ 16

2.4.3. Potássio............................................................. 18

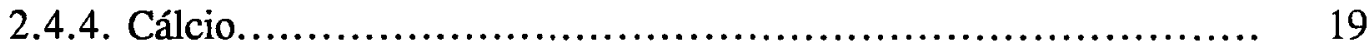

2.4.5. Magnésio.................................................... 21

2.4.6. Enxofre......................................................... 22

3. MATERIAL E MÉTODOS................................................. 24

3.1. Localização do experimento........................................... 24

3.2. Coleta e preparo da amostra.......................................... 24

3.3. Caracterização química do substrato.................................. 25

3.4. Tratamentos....................................................... 27 
3.5. Delineamento experimental e análise estatística....................... 27

3.6. Instalação e condução do experimento............................... 39

3.7. Irrigação........................................................ 31

3.8. Desbaste e adubação em cobertura................................... 31

3.9. Colheita das plantas............................................. 32

3.10. Análise química das plantas..................................... 32

3.11. Parâmetros avaliados.............................................. 33

4. RESULTADOS E DISCUSSÃO..................................... 34

4.1. Crescimento e nutrição mineral do milho............................ 34

4.2. Produção de matéria seca........................................ 34

4.3. Concentração mineral e quantidades acumuladas na parte aérea das plantas..................................................... 50

4.3.1. Teores na parte aérea das plantas e $\mathrm{N}$ absorvido................ 50

4.3.2. Teores na parte aérea das plantas e P absorvido................. 59

4.3.3. Teores na parte aérea das plantas e $\mathrm{K}$ absorvido................ 71

4.3.4. Teores na parte aérea das plantas e $\mathrm{Ca}$ absorvido................ 76

4.3.5. Teores na parte aérea das plantas e $\mathrm{Mg}$ absorvido............... 86

4.3.6. Teores na parte aérea das plantas e $S$ absorvido................. 96

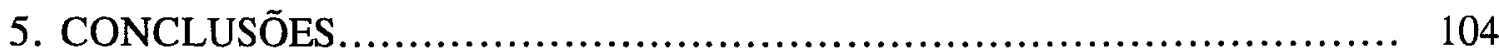

REFERÊNCIAS BIBLIOGRÁFICAS................................ 107

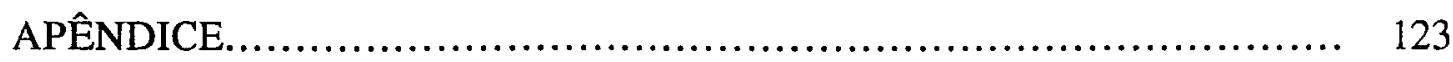




\section{LISTA DE QUADROS}

QUADRO

Página

1 Características químicas da amostra de terra, coletada na camada de

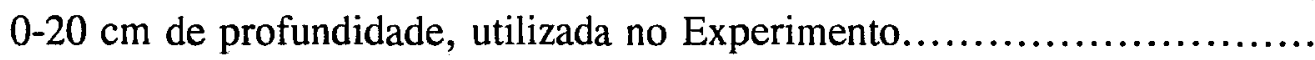

2 Quantidades de cálcio e magnésio adicionadas ao solo estudado em diferentes relações $\mathrm{Ca}: \mathrm{Mg}$ estabelecidas nos sais......................... 28

3 Quantidades e fontes de micronutrientes utilizados no estudo............... 30

4 Produção de matéria seca $\left(\mathrm{g} \mathrm{vaso}^{-1}\right)$ e extração de macronutrientes (mg vaso-1) por plantas de milho, segundo os tratamentos, 42 dias após o plantio, média de 4 repetições

5 Teores de macronutrientes (\%) encontrados na matéria seca da parte aérea das plantas de milho, segundo os tratamentos, 42 dias após o plantio, média de 4 repetições

6 Resumo das análises de variância dos dados relativos à matéria seca e quantidade de macronutrientes absorvida e acumulada na parte aé-

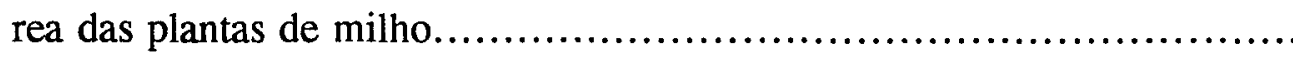

7 Resumo das análises de variância dos dados relativos aos teores de macronutrientes na matéria seca da parte aérea das plantas de milho........ 
8 Produção de matéria seca (g vaso ${ }^{-1}$ ) e quantidade acumulada de macronutrientes na parte aérea das plantas de milho (mg vaso ${ }^{-1}$, em função das saturações por bases..........................................

9 Produção de matéria seca $\left(\mathrm{g} \mathrm{vaso}^{-1}\right)$ e quantidade acumulada de macronutrientes na parte aérea das plantas de milho $\left(\mathrm{mg} \mathrm{vaso}^{-1}\right)$, em função das relações $\mathrm{Ca}: \mathrm{Mg}$ no solo.

10 Produção de matéria seca (g vaso ${ }^{-1}$ ) e quantidade acumulada de macronutrientes na parte aérea das plantas de milho $\left(\mathrm{mg} \mathrm{vaso}^{-1}\right)$, em função das doses de $\mathrm{P}$ aplicadas no solo

11 Produção de matéria seca das plantas de milho (g vaso-1), em função das relações Ca:Mg no solo e saturações por bases.......................

12 Produção de matéria seca das plantas de milho (g vaso ${ }^{-1}$ ), em função das relações Ca: $\mathrm{Mg}$ no solo e doses de $\mathrm{P}$ aplicadas.

13 Produção de matéria seca das plantas de milho ( $\mathrm{g} v a s o^{-1}$ ), em função das saturações por base e doses de P aplicadas.

14 Produção de matéria seca das plantas de milho ( $\mathrm{g}$ vaso ${ }^{-1}$ ), em função dos tratamentos

15 Teores de macronutrientes na matéria seca da parte aérea das plantas de milho (\%), em função das saturações por bases.........................

16 Teores de macronutrientes na matéria seca da parte aérea das plantas de milho (\%), em função das relações Ca: $\mathrm{Mg}$ no solo 
17 Teores de macronutrientes na matéria seca da parte aérea das plantas de milho (\%), em função das doses de $\mathrm{P}$ aplicadas

18 Teores de $\mathrm{N}$ na matéria seca da parte aérea das plantas de milho (\%), em função das relações Ca:Mg no solo e saturações por bases.

19 Teores de $\mathrm{N}$ na matéria seca da parte aérea das plantas de milho (\%), em função das relações Ca: $\mathrm{Mg}$ no solo e doses de $\mathrm{P}$ aplicadas.

20 Teores de $\mathrm{N}$ na matéria seca da parte aérea das plantas de milho (\%), em função das saturações por bases e doses de P aplicadas.

21 Teores de $\mathbf{N}$ na matéria seca da parte aérea das plantas de milho (\%), em função dos tratamentos.

22 Teores de P na matéria seca da parte aérea das plantas de milho (\%), em função das relações $\mathrm{Ca}: \mathrm{Mg}$ no solo e saturações por bases.

23 Teores de P na matéria seca da parte aérea das plantas de milho (\%), em função das relações $\mathrm{Ca}: \mathrm{Mg}$ no solo e doses de $\mathrm{P}$ aplicadas.

24 Teores de P na matéria seca da parte aérea das plantas de milho (\%), em função das saturações por bases e doses de P aplicadas................

25 Teores de P na matéria seca da parte aérea das plantas de milho (\%), em função dos tratamentos.

26 Quantidade acumulada de P na parte aérea das plantas de milho (mg vaso $^{-1}$ ), em função das relações Ca:Mg no solo e saturações por bases..... 
27 Quantidade acumulada de P na parte aérea das plantas de milho (mg vaso $^{-1)}$, em função das relações $\mathrm{Ca}: \mathrm{Mg}$ no solo e doses de $\mathrm{P}$ aplicadas......

28 Quantidade acumulada de P na parte aérea das plantas de milho (mg vaso $\left.^{-1}\right)$, em função das saturações por bases e doses de $\mathrm{P}$ aplicadas..........

29 Quantidade acumulada de P na parte aérea das plantas de milho (mg vaso $\left.^{-1}\right)$, em função dos tratamentos.

30 Teores de $\mathrm{K}$ na matéria seca da parte aérea das plantas de milho (\%), em função das relações Ca: $\mathrm{Mg}$ no solo e doses de $\mathrm{P}$ aplicadas.

31 Teores de $\mathrm{K}$ na matéria seca da parte aérea das plantas de milho (\%), em função das saturações por bases e doses de $\mathrm{P}$ aplicadas

32 Teores de $\mathrm{K}$ na matéria seca da parte aérea das plantas de milho (\%), em função dos tratamentos.

33 Teores de Ca na matéria seca da parte aérea das plantas de milho (\%), em função das relações Ca: $\mathrm{Mg}$ no solo e doses de $\mathrm{P}$ aplicadas.

34 Teores de Ca na matéria seca da parte aérea das plantas de milho (\%), em função das saturações por bases e doses de P aplicadas.................

35 Teores de Ca na matéria seca da parte aérea das plantas de milho (\%), em função dos tratamentos...............................................

36 Quantidade acumulada de Ca na parte aérea das plantas de milho (mg vaso $^{-1}$ ) em função das relações $\mathrm{Ca}: \mathrm{Mg}$ no solo e saturações por bases 
37 Quantidade acumulada de Ca na parte aérea das plantas de milho (mg vaso $^{-1}$ ) em função das relações Ca: $\mathrm{Mg}$ no solo e doses de $\mathrm{P}$ aplicadas......

38 Quantidade acumulada de Ca na parte aérea das plantas de milho (mg vaso $^{-1}$ ) em função das saturações por bases e doses de $\mathrm{P}$ aplicadas..........

39 Quantidade acumulada de Ca na parte aérea das plantas de milho (mg

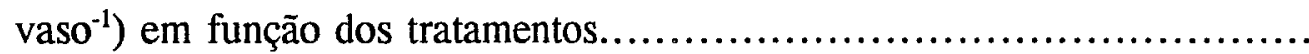

40 Teores de Mg na matéria seca da parte aérea das plantas de milho (\%), em função das relações $\mathrm{Ca}: \mathrm{Mg}$ no solo e saturações por bases.............

41 Teores de Mg na matéria seca da parte aérea das plantas de milho (\%), em função das relações $\mathrm{Ca}: \mathrm{Mg}$ no solo e doses de $\mathrm{P}$ aplicadas

42 Teores de $\mathrm{Mg}$ na matéria seca da parte aérea das plantas de milho (\%), em função das saturações por bases e doses de P aplicadas.................

43 Teores de Mg na matéria seca da parte aérea das plantas de milho (\%), em função dos tratamentos.............................................

44 Quantidade acumulada de $\mathrm{Mg}$ na parte aérea das plantas de milho (mg vaso $^{-1}$ ), em função das relações Ca:Mg no solo e saturações por bases....

45 Quantidade acumulada de $\mathrm{Mg}$ na parte aérea das plantas de milho (mg vaso $^{-1}$ ), em função das relações Ca: $\mathrm{Mg}$ no solo e doses de $\mathrm{P}$ aplicadas.....

46 Quantidade acumulada de $\mathrm{Mg}$ na parte aérea das plantas de milho (mg vaso $\left.^{-1}\right)$, em função das saturações por bases e doses de $\mathrm{P}$ aplicadas. 
47 Quantidade acumulada de Mg na parte aérea das plantas de milho (mg

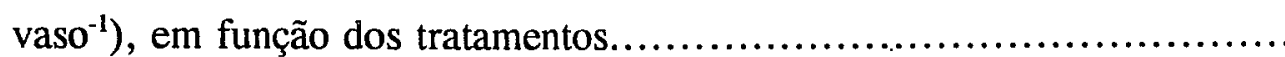

48 Teores de S na matéria seca da parte aérea das plantas de milho (\%), em função das relações Ca:Mg no solo e saturações por bases.............. 97

49 Teores de $\mathrm{S}$ na matéria seca da parte aérea das plantas de milho (\%), em função das relações Ca: $\mathrm{Mg}$ no solo e doses de P aplicadas.............. 98

50 Quantidade acumulada de $\mathrm{S}$ na parte aérea das plantas de milho (mg vaso $\left.^{-1}\right)$, em função das relações Ca:Mg no solo e saturações por bases.....

51 Quantidade acumulada de $\mathrm{S}$ na parte aérea das plantas de milho (mg vaso $^{-1}$ ), em função das relações Ca:Mg no solo e doses de $\mathrm{P}$ aplicadas.....

52 Quantidade acumulada de S na parte aérea das plantas de milho (mg vaso $^{-1}$ ), em função das saturações por bases e doses de $\mathrm{P}$ aplicadas.........

53 Quantidade acumulada de S na parte aérea das plantas de milho (mg vaso $^{-1}$ ), em função dos tratamentos 
EFEITO da SATURAÇÃO POR BASES, RELAÇÕES Ca:Mg NO SOLO

E NÍVEIS DE FÓSFORO SOBRE A PRODUÇÃo DE MATÉRIA SECA

E NUTRIÇÃO MINERAL DO MILHO (Zea mays L.)

\author{
Autor: ROGER JESUS MUÑOZ HERNÁNDEZ \\ Orientador: Prof. Dr. RONALDO IVAN SILVEIRA
}

\title{
RESUMO
}

O experimento foi realizado sob condições de casa de vegetação do Departamento de Ciência do Solo da Escola Superior de Agricultura "Luiz de Queiroz", USP, visando avaliar o efeito de dois niveis de saturação por bases, das aplicações de cálcio e magnésio em quatro relações de Ca: $\mathrm{Mg}$ e três doses de $\mathrm{P}$, sobre a nutrição mineral e produção de matéria seca de milho (Zea mays, L.).

O solo foi coletado na camada de $0-20 \mathrm{~cm}$ e o ensaio conduzido em vasos de $3 \mathrm{~kg}$, sob delineamento inteiramente casualizado, esquema fatorial $2 \times 4 \times 3$, com 4 repetições, sendo 2 saturações por bases $(50$ e 70\%), 4 relações Ca:Mg no corretivo $(2: 1,3: 1,4: 1$ e $5: 1)$ obtidos pela aplicação de $\mathrm{CaCO}_{3}$ e $\mathrm{MgO}, 3$ doses de $\mathrm{P}(0,100$ e 200 ppm) pela adição de $\mathrm{NH}_{4} \mathrm{H}_{2} \mathrm{PO}_{4}$. 
O solo estudado foi incubado com o material corretivo referente aos tratamentos, por 21 dias, quando se efetuou a aplicação dos tratamentos referentes às doses de $\mathrm{P}$.

A colheita foi efetuada aos 42 dias do plantio. A matéria seca do milho, a concentração e a absorção de nutrientes pelas plantas, foram avaliadas.

Os resultados obtidos demonstraram que o aumento na saturação por bases influenciou positivamente o crescimento e a nutrição do milho. Houve redução na produção de matéria seca da parte aérea com aumentos na relação $\mathrm{Ca}: \mathrm{Mg}$ no corretivo, sendo as maiores produções obtidas na relação Ca: Mg 3:1, com a aplicação de 100 ppm de P. Evidenciaram-se decréscimos dos teores de $\mathrm{N}, \mathrm{K}$ e $\mathrm{S}$ no tecido e de incrementos de $\mathrm{P}$, Ca e Mg com aumento da saturação por bases, enquanto as quantidades de nutrientes absorvidos para o $\mathrm{N}$ e o $\mathrm{K}$ diminuiram com aumento da saturação por bases e incrementaram para $\mathrm{P}, \mathrm{Ca}, \mathrm{Mg}$ e $\mathrm{S}$. Houve redução nos teores e na absorção de $\mathrm{P}, \mathrm{Mg}$ e $\mathrm{S}$ e incremento nos teores e na absorção de $\mathrm{Ca}$, com aumentos na relação Ca:Mg no corretivo.

O P aplicado no solo promoveu incrementos significativos na matéria seca do milho e aumentou a concentração deste elemento no tecido das plantas e diminuiu a de $\mathrm{N}, \mathrm{K}, \mathrm{Ca}, \mathrm{Mg}$ e S. O P aplicado aumentou as quantidades absorvidas para $\mathrm{N}, \mathrm{P}, \mathrm{K}, \mathrm{Ca}$, Mg e S. Duplas interações entre relação Ca:Mg x doses de $\mathrm{P}$ e saturação por bases x doses de $\mathrm{P}$ aumentaram a concentração de $\mathrm{P}$ no tecido das plantas e diminuiram a de $\mathrm{N}$, $\mathrm{K}$, Ca e $\mathrm{Mg}$. A interação relação $\mathrm{Ca}: \mathrm{Mg} \mathrm{x}$ saturação por bases aumentou as 
concentrações de $\mathrm{P}$ e $\mathrm{Mg}$ no tecido das plantas e diminuiu as de $\mathrm{N}$ e $\mathrm{S}$. As duplas interações aumentaram o acúmulo de $\mathrm{P}, \mathrm{Ca}$ e $\mathrm{Mg}$ nos tecidos.

De modo geral, conclui-se que a saturação por bases, as relaçōes $\mathrm{Ca}: \mathrm{Mg}$ no corretivo e a adubação fosfatada do solo utilizado, afetaram o crescimento e a nutrição mineral do milho. $\mathrm{O}$ teor nos tecidos e o acúmulo de nutrientes foram influenciados pela disponibilidade dos nutrientes para as plantas, bem como pelo equilibrio entre os mesmos no solo. 


\title{
EFFECT OF SOIL BASE SATURATION, Ca:Mg IN SOIL AND LEVELS \\ OF PHOSPHORUS ON DRY MATTER PRODUCTION AND MINERAL \\ NUTRITION OF CORN (Zea mays L.)
}

\author{
Author: ROGER JESUS MUÑOZ HERNÁNDEZ \\ Adviser: Prof. Dr. RONALDO IVAN SILVEIRA
}

\section{SUMMARY}

The experiment was carried out under green house conditions of Soil Science Department at Agriculture Superior School "Luiz of Queiroz", USP, SP, in order to evaluate the effect of two levels of soil base saturation, applications of calcium and magnesium to give four $\mathrm{Ca}: \mathrm{Mg}$ ratios and three levels of $\mathrm{P}(0,100$ and $200 \mathrm{ppm})$ on mineral nutrition and dry matter production of corn (Zea mays L.).

The soil was collected in the $0-20 \mathrm{~cm}$ depth and the experiment was conducted in a $3 \mathrm{~kg}$ size pot trial with completely randomized experimental design in a $2 \times 4 \times 3$ factorial scheme, with four replications, given lime to adjust soil base saturation (50 or $70 \%)$, four ratios $\mathrm{Ca}: \mathrm{Mg}$ in the lime $(2: 1,3: 1,4: 1$ or $5: 1)$ obtained with the applications of $\mathrm{CaCO}_{3}$ and $\mathrm{MgO}$ and $\mathrm{NH}_{4} \mathrm{H}_{2} \mathrm{PO}_{4}$ to provide 0,100 and $200 \mathrm{ppm}$ of $\mathrm{P}$. 
The soil was incubated with lime treatments for 21 days, when were applied $\mathrm{P}$ levels.

The plants were harvested at 42 days after planting. Corn herbage dry weights, plant nutrient concentrations and uptake were evaluated.

The results showed that increases in soil base saturation influenced positively corn growth and nutrition. There was a decreasing in dry matter production of tops with the increase in the lime Ca: $\mathrm{Mg}$ ratios. The highest productions were obtained with $3: 1$ Ca: $\mathrm{Mg}$ ratio and application of $100 \mathrm{ppm} \mathrm{P}$. Decreases in the concentration of $\mathrm{N}, \mathrm{K}, \mathrm{S}$ and increases in the concentrations of $\mathrm{P}, \mathrm{Ca}, \mathrm{Mg}$ with the increasing in soil base saturation were observed. Plant $\mathrm{N}$ and $\mathrm{K}$ total uptake decreased as soil base saturation increased. In the other way, plant $\mathrm{P}, \mathrm{Ca}, \mathrm{Mg}$ and $\mathrm{S}$ total uptake increased as soil base saturation increased. There was a decreasing in the concentration and plant $\mathrm{P}, \mathrm{Mg}$ and $\mathrm{S}$ total uptake with the increasing an the $\mathrm{Ca}: \mathrm{Mg}$ ratio. Increases in the concentration and plant Ca total uptake with increases in $\mathrm{Ca}: \mathrm{Mg}$ ratios were observed.

The addition of $\mathrm{P}$ to the soil promoted significant increases in corn dry matter and improved the concentration of this element in plant tissue, but decreased the concentrations of $\mathrm{N}, \mathrm{K}, \mathrm{Ca}, \mathrm{Mg}$ and $\mathrm{S}$. The $\mathrm{P}$ applied increased plant $\mathrm{N}, \mathrm{P}, \mathrm{K}, \mathrm{Ca}, \mathrm{Mg}$ and $\mathrm{S}$ total uptake. Double interactions among $\mathrm{Ca}: \mathrm{Mg}$ ratio $\mathrm{x}$ levels of $\mathrm{P}$ and soil base saturation $\mathrm{x}$ levels of $\mathrm{P}$ increased the concentration of $\mathrm{P}$ in plant tissue, but decreased the concentrations of $\mathrm{N}, \mathrm{K}, \mathrm{Ca}$ e $\mathrm{Mg}$. The interaction $\mathrm{Ca}: \mathrm{Mg}$ x soil base saturation 
increased the concentration of $\mathrm{P}$ and $\mathrm{Mg}$ in plant tissue and decreased the concentrations of $\mathrm{N}$ and $\mathrm{S}$. The double interactions increased accumulation of $\mathrm{P}, \mathrm{Ca}$ and $\mathrm{Mg}$ in tissues.

In a general manner, it was concluded that soil base saturation, $\mathrm{Ca}: \mathrm{Mg}$ ratios and soil phosphatic fertilization affected corn growth and mineral nutrition. The concentration and accumulation in plant tissues were influenced by the availability of nutrients by plants and their balance in the soil. 


\section{INTRODUÇÃo}

As áreas utilizadas na expansão da fronteira agrícola, geralmente são de baixa fertilidade natural, por serem solos muito intemperizados, que é um fator limitante ao crescimento e desenvolvimento das plantas, devido à acidez elevada, altos valores de saturação de alumínio na camada arável, baixas concentrações das bases trocáveis, principalmente cálcio e magnésio, e baixos teores de fósforo. $\mathrm{O}$ principal efeito da acidez na fertilidade do solo, está na associação entre o pH e as modificações na composição da solução do solo, através da sua influência na solubilidade e disponibilidade de nutrientes.

Conseqüentemente, para elevar a produtividade das culturas introduzidas nessas áreas, e para obter rendimentos agrícolas economicamente satisfatórios, são de suma importância, práticas de manejo dos solos para contornar essas limitações, como incorporação de calcários, adubação equilibrada, uso de variedades tolerantes, etc.

A aplicação de calcário é uma das práticas usadas para corrigir a acidez e aumentar a disponibilidade dos elementos minerais, que têm sua faixa de melhor disponibilidade entre um $\mathrm{pH}$ de 6,0 e 6,5, neutralizar o excesso de alumínio, ferro e 
manganês tóxicos às plantas. $\mathrm{O}$ fornecimento de cálcio e do magnésio interfere na fixação e na retrogradação do fósforo.

A concentração de um nutriente na solução do solo é função da sua quantidade trocável e do seu grau de saturação no complexo de troca, além da natureza dos outros íons adsorvidos. São importantes os efeitos de interação que ocorrem no complexo de troca quando se adiciona mais de um cátion no sistema, e doses excessivas, o que resulta em desbalanços nutricionais entre os cátions no solo, principalmente entre o cálcio o magnésio, estabelecendo uma inibição competitiva entre os cátions na solução, podendo induzir deficiências nutricionais nas plantas, causando queda na produção.

É de grande importância o balanço iônico e as interações entre os cátions, cálcio e magnésio, fornecendo as quantidades adequadas e equilibradas desses nutrientes para atender às exigências das plantas.

A maioria dos solos ácidos apresentam baixos teores de fósforo na solução de solo devido à grande capacidade de adsorção do nutriente pela fase sólida, o que torna a eficiência da adubação fosfatada, um fator limitante na produção econômica.

Para a incorporação desses solos marginais no processo produtivo, é necessário a adição de corretivos e minimizar a retenção do fósforo aplicado ao solo, aumentando a sua disponibilidade para as plantas.

Com base nessas premissas e ante a necessidade de estudos específicos de proporções Ca:Mg em relação a saturação por bases, além do baixo teor de fósforo disponível às plantas, como fator limitante dos solos da região tropical brasileira na 
produtividade agrícola e pela importância e necessidade de conduzir estudos sobre aspectos nutricionais, principalmente com respeito à absorção de nutrientes, propõe-se a realização deste trabalho de pesquisa com o objetivo de avaliar o efeito das aplicações de cálcio e magnésio em quatro relações $\mathrm{Ca}: \mathrm{Mg}$, dois níveis de saturação por bases e da adubação fosfatada, sobre o conteúdo e distribuição de nutrientes no milho. 


\section{REVISÃO DE LITERATURA}

\subsection{Nutrição mineral em plantas: Considerações gerais}

No processo de absorção, as interações catiônicas nos sítios de adsorção e a concentração de íons nutrientes na solução do solo, constituem aspectos de importância na nutrição das plantas e produção das culturas (KHASAWNEH, 1971). A taxa de absorção de um nutriente pela planta depende dos cátions dissolvidos na solução do solo, em equilíbrio dinâmico com os cátions do complexo de troca (BULL, 1986).

A disponibilidade e absorção de determinado íon pelas plantas não atinge o equilíbrio no sistema Solo-Solução-Raíz-Parte Aérea, devido à movimentação do nutriente do solo no processo de absorção e a translocação dentro da planta (REICHARDT, 1986).

O balanço nutricional das plantas não depende somente das interações das espécies iônicas na superfície de troca do solo e da concentração na solução do solo; certas condições do ambiente e da fisiologia da própria planta, dificultam a absorção do nutriente, o que leva ao aparecimento de deficiências nutricionais na planta, que podem prejudicar o crescimento e rendimento vegetal (VOLKWEISS, 1986). 
Dentre os fatores que afetam a absorção de um nutriente pelas plantas, devem ser considerados os tipos de colóides, o pH, o equílibrio entre a quantidade trocável no solo e a concentração do nutriente na solução do solo e a influência da atividade dos íons na mobilidade na solução do solo. A adsorção de um íon depende também, da energia de ligação às argilas, os cátions de maior densidade de carga (relação valência/grau de hidratação) apresentam uma adsorção mais forte ao colóide (COELHO \& VERLENGIA, 1973; KIEHL, 1979). A absorção de um nutriente é afetada também pela natureza dos cátions complementares, isto é, a influência de um íon adsorvido sobre a liberação de um outro, para a solução do solo, a partir da superfície trocadora e das relações que envolvem os catíons no solo (TISDALE et al., 1985).

Desde o ponto de vista fisiológico, existem diferenças entre espécies ou variedades de plantas na eficiência de absorção dos íons no ciclo produtivo, que são atribuidas às características anatômicas e morfológicas dos sistemas radiculares (MALAVOLTA et al., 1989).

Na avaliação da capacidade potencial de fertilidade dos solos, devem ser ajustadas as relações entre cátions para a cultura, em vista das interações competitivas entre diferentes íons nutrientes que influem na disponibilidade e possibilidade de absorção, a nível de membrana, pela entrada do íon na célula (EPSTEIN, 1975). 


\subsection{Dinâmica dos cátions cálcio e magnésio no solo}

Apesar da importância do uso da calagem com fins agrícolas como prática de manejo do solo, é necessário considerar a relação Ca: $\mathrm{Mg}$ do corretivo.

Relações Ca:Mg desfavoráveis resultam, além das relações entre cátions no solo, da aplicação de corretivos que fornecem relações inadequadas de cálcio e magnésio.

Tem-se verificado que a calagem, além de diminuir a saturação por alumínio trocável, aumenta o pH e os teores de cálcio e/ou magnésio no solo.

A aplicação de calcário para o suprimento de cálcio e/ou magnésio influi no equilíbrio nutricional, através das interações que involvem os cátions cálcio e magnésio no solo e na planta (SIQUEIRA et al., 1975). Portanto, o fornecimento equilibrado de cátions básicos e a eficiência das plantas em obter quantidades suficientes de um nutriente, depende da associação dos valores da relação Ca: $\mathrm{Mg}$ do corretivo, com aqueles encontrados na análise do solo.

Entretanto, a calagem excessiva pode promover menor absorção de magnésio pelas plantas, reduzindo seu teor nos tecidos (CRISTENSON et al., 1973). O uso contínuo de calcário calcítico pode acarretar desbalanços nutricionais por um excesso de cálcio na solução do solo e pode resultar em relações desfavoráveis $\mathrm{Ca}: \mathrm{Mg}$, prejudicando a absorção de magnésio, com queda na produção (FARINA et al., 1980). $\mathrm{O}$ uso de calcário dolomítico prejudica a absorção de cálcio por um excesso de 
magnésio (GROVE et al., 1981). Da mesma forma, o excesso de cálcio e potássio em relação ao magnésio, pode induzir uma deficiência do último (COELHO \& VERLENGIA, 1973).

Diversos estudos informam que as relações ideais de $\mathrm{Ca}$ e $\mathrm{Mg}$ no solo dependem da concentração de cálcio e magnésio no solo, da exigência da cultura, da dose do corretivo utilizado, do teor de cálcio e/ou magnésio do corretivo.

MALAVOLTA (1987) sugere manter uma relação Ca:Mg de 3:1, ao determinar a necessidade de calagem, com a incorporação de calcário calcítico, rico em cálcio, se a relação está próxima de 1:1 e de calcário dolomítico, rico em magnésio, quando a relação Ca:Mg ultrapassa o valor 3:1.

SILVA (1980), realizando estudo sobre nutrição do milho observou maior produção da parte aérea e de raízes na relação Ca:Mg de 3:1. EMBRAPA (1983) recomenda, para essa cultura, relações Ca:Mg no corretivo de 3 a 5:1. ARANTES (1983), ao testar doses de corretivo, relações Ca:Mg e níveis de potássio, observou que a relação Ca:Mg de 5:1 estabelecida com o corretivo com o qual a saturação de bases se elevou até $60 \%$ promoveu uma maior produção de matéria seca no milho.

SFREDO (1976), estudando a influência de relações Ca:Mg variáveis em sorgo, mostrou que, para a matéria seca não ser prejudicada, o equilibrio no material corretivo e no solo, devem ser superiores de 1:1 e 0,5:1, respectivamente. SANIK et al. (1952), ao avaliar o efeito da relação Ca: $\mathrm{Mg}$ na nutrição de sorgo, mostraram que a maior produção foi obtida na relação $4: 1$. 
FERREIRA et al. (1979), recomendam a relação Ca:Mg de 1:1,5 como ótima para a soja. SOUZA et al. (1985), notaram que a maior produção de matéria seca de soja foi obtida na relação Ca: $\mathrm{Mg}$ 3:1. Esses autores indicaram ainda, efeitos depressivos quando a relação Ca:Mg foi de 35 e 70:1, ou com aplicação de magnésio sem cálcio. Estudando a influência da aplicação de calcário na produção de soja, GALLO et al. (1956), observaram maiores produções de hastes e folhas ao usar uma relação Ca:Mg de $9: 1$.

Em estudo com aveia, JASKOWISKY (1970) encontrou uma relação Ca:Mg de 3:1 como sendo a melhor e conclui que o cálcio exerce uma maior influência na movimentação de magnésio no solo do que na neutralização da acidez do solo.

Em estudo com cana-de-açúcar, PIMENTEL (1986) determinou que a relação Ca:Mg para o equilíbrio nutricional ótimo foi de 5:1. PEIXOTO (1980), avaliou em cana-de-açúcar, o efeito da relação Ca: $\mathrm{Mg}$ na forma de carbonatos e níveis de potássio. Os resultados mostram máximo de produção com a relação Ca:Mg 5,5:1. CHAVES SOLERA (1988), ao avaliar relações Ca:Mg variáveis na forma de carbonatos e sulfatos sobre a produção de matéria seca em cana-de-açúcar, encontrou que as relações $\mathrm{Ca}: \mathrm{Mg}$ 4,86:1 e 10,34:1, nos tratamentos com carbonatos e sulfatos, respectivamente, propiciaram as produções máximas de matéria seca total.

Conduzindo experimentos com tomate, LIMA (1979) observou que as maiores produções de matéria seca num Latossolo Vermelho-Escuro (LVE) foram obtidas como as relações $\mathrm{Ca}: \mathrm{Mg}$ no solo e no corretivo de 1:1 e 1,8:1. Com uma relação (Ca + 
$\mathrm{Mg}$ )/K no solo de 10,5, no entanto, para um Latossolo Humico (LH), as melhores relações foram 0,8:1 e 1,1:1, respectivamente, e uma relação (Ca: $\mathrm{Mg}$ )/K de 26,3.

SILVA (1986), ao avaliar relaçōes Ca:Mg do corretivo na produção de mudas de eucalipto, obteve as máximas produções de matéria seca com a relação Ca:Mg no solo de 1,03 a $0,40: 1$, o equilibrio ótimo do corretivo foi $5 \% \mathrm{Ca}: 95 \% \mathrm{Mg}$ ou $24,5 \%$ Ca: $75,5 \% \mathrm{Mg}$, sendo que a concentração crítica de cálcio e magnésio na planta, situou-se na faixa de $0,23-0,53 \%$ e $0,15-0,30 \%$ respectivamente.

BESEDIN (1966), em estudo com milheto verificou que o melhor equilíbrio está nas relações Ca:Mg 1:1 e 1:2.

As relações calculadas para se identificar a melhor proporção entre cátions, em solos e culturas, nem sempre se correlacionam bem com a produção (USHERWOOD, 1982).

KEY et al. (1962), não verificaram efeito das relações Ca: $\mathrm{Mg}$ na produção de matéria seca de milho e sorgo e concluiram que os teores originais de cálcio e magnésio no solo eram adequados.

ROSOLEM et al. (1984), ao avaliar o efeito da adição de magnésio aplicado como $\mathrm{MgSO}_{4}$, na ausência e presença de calagem calcítica e de adubação potássica, não observaram influência das relações $\mathrm{Ca}: \mathrm{Mg}$ no solo, na produção de matéria seca de sorgo sacarino.

ARAUJO (1977), estudando o efeito de doses de corretivo e relações Ca: $\mathrm{Mg}$ na forma de óxido, não observou influência significativa da relação $\mathrm{Ca}: \mathrm{Mg}$, na produção 
de matéria seca de soja. MUCHOVEJ (1980), avaliando relações Ca:Mg variáveis na forma de carbonatos, não obteve diferenças na produção de matéria seca da parte aérea da soja, com relações no solo variando de 0,26:1 até 24:1.

MELLO \& KAMINSKY (1990), estudando o efeito da relação Ca:Mg do corretivo e da nutrição potássica na produção e composição catiônica de aveia, notaram que as relações $\mathrm{Ca}: \mathrm{Mg}$ no solo não tiveram efeito na produção de matéria seca e concluiram que os nutrientes cálcio e magnésio estavam presentes em quantidades suficientes no solo.

Estudando o efeito de relações Ca: $\mathrm{Mg}$ variáveis em solução nutritiva e solo, para predizer a relação $\mathrm{Ca} /(\mathrm{Ca}+\mathrm{Mg})$ ideal para fins nutricionais, ROSSI et al. (1988), não verificaram efeito significativo da relação $\mathrm{Ca}: \mathrm{Mg}$ sobre a produção de matéria seca da parte aérea e raízes do trigo.

HALSTEAD et al. (1958), avaliaram relações Ca:Mg variáveis na forma de carbonatos em dois solos e não constaram efeito dos tratamentos nos rendimentos de alfafa.

Tem sido relatado, com referência às relações Ca:Mg trocáveis no solo, que existe interação do cálcio e do magnésio na nutrição das plantas. Assim, o cálcio e o magnésio interferem-se mutuamente de modo competitivo, na absorção.

Em estudo com milho, GROVE \& SUMMER (1985) notaram um incremento nos teores de magnésio e na absorção desse elemento em solos ácidos, provocado por adições de calcário calcítico, porém, com o aumento gradativo do corretivo, observaram 
uma redução do magnésio trocável, do magnésio absorvido, da matéria seca da parte aérea e da absorção de fósforo e zinco.

JUO \& UZO (1977), estudando a influência da calagem em dois solos da Nigéria, notaram que a absorção de magnésio, manganês e o zinco em plantas de milho, foi deprimida em função da dose do corretivo utilizada.

ADAMS \& HENDERSON (1962), notaram uma redução na absorção de magnésio em solos deficientes nesse íon, ao corrigir a acidez do solo com aumento do pH para 6,5, porém, em solos não deficientes em magnésio, a absorção foi aumentada. CRISTENSON et al. (1973), observaram maior influência do pH do solo do que do cálcio do solo na absorção de magnésio e concluiram que o efeito do $\mathrm{pH}$ na absorção de magnésio, se apresenta quando a concentração de magnésio no solo é baixa.

Realizando estudo sobre nutrição da beterraba, DURRANT \& DRAYCOTT (1971) notaram que a aplicação de magnésio provocou decréscimo na absorção de cálcio, porém, não observaram nenhuma influência do magnésio sobre a absorção de potássio.

Em estudo com maçã, PAVAN et al. (1987) observaram um decréscimo da concentração de cálcio na parte aérea e redução da translocação do cálcio dentro das raízes, provocado por um aumento na concentração de magnésio no solo.

SFREDO (1976) trabalhando com sorgo, notou que aumentos no teor de magnésio, aplicado na relação $\mathrm{Ca}: \mathrm{Mg}$ eram acompanhados por decréscimos na produção, devido a esse elemento influir, por antagonismo, na deficiência de cálcio. 


\subsection{Dinâmica do fósforo no solo}

A aplicação de fertilizante fosfatado solúvel libera íons fosfato durante a dissolução, que tende a passar a formas menos solúveis ao reagir com constituintes do solo. Esse processo é conhecido como retenção ou fixação de fósforo que ocorre através de dois mecanismos: precipitação, que consiste na formação de compostos insolúveis ou de baixa solubilidade e adsorção, que é a retenção do fósforo solúvel na superfície de alguns constituintes do solo. Esse fenômeno é muito importante em solos fortemente intemperizados, normalmente ácidos (BUCKMAN \& BRADY, 1974; FASSBENDER, 1984).

A solução do solo constitui a fonte imediata de fósforo para as plantas. A maior parte do fósforo adicionado ao solo não permanece estável, passa para a fase sólida, devido à grande tendência de retenção do íon fosfato nos solos, constituindo o fósforo lábil, representado por formas metaestáveis em equilíbrio com o fósforo da solução. $\mathrm{O}$ fósforo lábil passa para fósforo não lábil, forma mineralógica mais estável e de difícil solubilização (RAIJ, 1987). A quantidade de fósforo absorvido pela planta dependeria do fósforo lábil, caracterizado como o fator quantidade ou a reserva de fósforo no solo, do fósforo em solução ou fator intensidade, do fator capacidade ou poder tampão do solo, uma medida da capacidade do solo em manter um nível definido de fósforo em solução, e do fator difusão, representado pelas características que permitem aos íons fosfato migrar da fase sólida do solo, até a superfície das raízes (RAIJ, 1991). 
VASCONCELLOS et al. (1982), informaram que a amostragem do solo em milho, quando a adubação fosfatada é realizada no sulco de plantio, deve ser efetuada após o preparo mecânico do terreno, para minimizar o erro amostral provocado pela dose de $\mathrm{P}_{2} \mathrm{O}_{5}$ utilizada.

WELCH et alli (1966), encontraram que a localização do fertilizante em solo com baixa concentração de fósforo, é prática inadequada para atingir a produção máxima, sendo necessária a aplicação suplementar a lanço. NOVAIS et al. (1985), informaram que a resposta do milho à adubação fosfatada no sulco do plantio, depende de um teor disponível do nutriente no restante da camada arável.

Em estudo com milho, CASTILHOS \& ANGHINONI (1983), verificaram a influência do método de aplicação de fósforo na disponibilidade do nutriente. Segundo os autores, quanto menor a fração do volume do solo fertilizado, a disponibilidade esperada do nutriente é maior, por uma dose relativa maior. NOVAIS et al. (1985), informam que a absorção do fósforo e o crescimento do milho dependem do contato do nutriente com o maior volume de raízes possível.

Por outra parte, estudos conduzidos por ANGHINONI \& BARBER (1980b) e CASTILHOS \& ANGHINONI (1988) em milho, mostraram que a redução do volume de solo fertilizada à disposição do sistema radicular, promoveu uma maior taxa de absorção pelas raizes e uma maior taxa de crescimento radicular, na solução nutritiva contendo fósforo. 
ANGHINONI \& BARBER (1980a), observaram que a aplicação de fósforo em frações decrescentes de volume de solo proporcionou um estímulo no desenvolvimento das raízes na fração do solo fertilizada, principalmente nas raízes mais finas.

CASTILHOS \& ANGHINONI (1983), não observaram nenhum efeito do teor de fósforo, no crescimento e distribuição das raízes de milho.

Tem-se constatado que a redução da fração inicial do sistema radicular exposta ao fostato, não provoca um incremento da área radicular. ANGHINONI \& BARBER (1980b), observaram que não houve compensação no incremento da área radicular do milho, quando menos que $50 \%$ do volume esteve em contato com fósforo na solução nutritiva.

No entanto, CASTILHOS \& ANGHINONI (1988), notaram maior absorção de fósforo por unidade de raiz exposta ao fósforo, quando menor volume radicular foi suprido por solução nutritiva contendo o nutriente.

Para se obter a máxima produção, ANGHINONI \& BARBER (1980a) constataram que uma redução de $25 \%$ do volume radicular exposto ao fosfato, provocou um estímulo no desenvolvimento das raízes e na absorção de fósforo no volume de solo fertilizado e promoveu a disponibilidade efetiva máxima de fósforo para o milho. 


\subsection{Macronutrientes no solo e na planta}

\subsubsection{Nitrogênio}

O nitrogênio é o nutriente exigido em maior quantidade pelas culturas. Não sendo constituinte de minerais primários, a principal fonte do elemento no solo é o nitrogênio do ar, que representa cerca de quatro quintos do volume, sendo o elemento predominante. No solo, o nitrogênio ocorre preferentemente em formas orgânicas, em uma enorme variedade de compostos ou radicais, que refletem a diversidade de compostos orgânicos existentes em plantas e em microrganismos do solo. Uma pequena parte do nitrogênio total do solo é encontrado nas formas minerais de amônio $\left(\mathrm{NH}_{4}{ }^{+}\right)$, nitrato $\left(\mathrm{NO}_{3}^{-}\right)$e nitrito $\left(\mathrm{NO}_{2}{ }^{-}\right)$, formas aproveitáveis pelas plantas e, de maior interesse para a nutrição vegetal (RAIJ, 1991).

A absorção de nitrogênio pelas plantas dá-se de diferentes formas: $\mathbf{N}_{2}$ no caso das leguminosas e outras espécies, aminoácidos, uréia, amoniacal e principalmente nítrica. Na planta, a maior parte do nitrogênio se encontra em formas orgânicas representadas, principalmente por aminoácidos e proteínas.

O nitrogênio é transportado no xilema e redistribuído preferentemente no floema, tanto o transporte quanto a redistribuição são relativamente rápidos (MALAVOLTA, 1980). 
O nitrogênio exerce uma função mais funcional do que estrutural, fazendo parte das proteínas, que participam como enzimas, nos processos metabólicos das plantas. $\mathrm{O}$ nitrogênio também é integrante na composição da molécula de clorofila (RAIJ, 1991).

A redistribuição de nitrogênio quando sobrevêm a sua falta, é um indicativo da mobilidade do elemento nas plantas. Na carência de nitrogênio nas plantas superiores, o elemento assimilado em órgãos mais velhos, principalmente folhas, transloca-se para folhas mais novas. Em conseqüência, a falta de nitrogênio começa nas folhas mais velhas (FERRI, 1985; MALAVOLTA, 1980; RAIJ, 1991).

Sintomas de deficiência de nitrogênio em milho aparecem na fase de crescimento mais intenso da planta, coincidindo com a maior demanda do elemento. As folhas mais velhas tornam-se cloróticas. Se persistir a deficiência, a clorose vai aumentando no sentido do ápice para o centro, com um $\mathrm{V}$ esbranquiçado ao longo da nervura principal. As espigas são deformadas, sem grãos na ponta (MALAVOLTA et al., 1974; MALAVOLTA et al., 1989).

\subsubsection{Fósforo}

O fósforo é o elemento cuja carência no solo, limita a produção, particularmente das culturas anuais, nas regiões tropicais e subtropicais (MALAVOLTA, 1980).

O fósforo é encontrado no solo nos minerais primários, nos minerais secundários, na matéria orgânica e na solução do solo (MELLO et al., 1989). 
$\mathrm{O}$ fósforo é absorvido pelas plantas preferencialmente como ion $\mathrm{H}_{2} \mathrm{PO}_{4}^{-}$, na faixa de $\mathrm{pH}$ que vai de 4 a 8 , em que vive a planta, predomina a espécie iônica $\mathrm{H}_{2} \mathrm{PO}_{4}{ }^{-}$. O transporte no xilema se faz principalmente nesta forma, podendo na seiva bruta aparecer o elemento como fosforil colina e ésteres de carboidrato. Na redistribuição de fósforo pelo floema, o elemento aparece principalmente como fosforil colina (MALAVOLTA, 1980).

O fósforo faz parte nos chamados compostos ricos de energia, o principal composto para armazenar energia, o ATP, participa das reações de síntese e desdobramento de carboidratos, inclusive do amido, da síntese de proteínas, da síntese e desdobramento de óleos e gorduras, do trabalho mecânico, da absorção salina (FERRI, 1985).

A rápida redistribuição de fósforo dos órgãos mais velhos para os mais novos na falta do elemento, faz com que as folhas mais velhas das plantas carentes em P sejam as primeiras a mostrar os sintomas (MALAVOLTA, 1980).

A deficiência de fósforo em milho se caracteriza pelas folhas velhas com tons roxos perto das margens, algumas vezes, os colmos tem a tendência de se tornarem roxos, coloração devido ao pigmento purpúreo, a antocianina. A maturação é tardia e as espigas curtas, com a ponta torta (MALAVOLTA et al., 1974; MALAVOLTA et al., 1989). 


\subsubsection{Potássio}

O potássio do solo encontra-se em minerais primários, como constituinte das argilas, fixado na matéria orgânica, adsorvido aos coloides do solo e na solução do solo (MELLO et al., 1989).

A absorção de potássio pelas plantas ocorre na forma iônica, $\mathrm{K}^{+}$, sendo o processo essencialmente ativo e servindo a solução do solo como fonte do nutrientes. O K absorvido pela raiz é conduzido à parte aérea pelo xilema e também pelo floema; sua redistribuição pelo segundo sistema de vasos é bastante fácil (MALAVOLTA, 1980).

As altas concentrações de $\mathrm{K}$ encontradas no tecido das plantas explicam a elevada permeabilidade das membranas a este nutriente. Cerca de $75 \%$ do $\mathrm{K}$ total existente na planta está em forma solúvel, o que permite entender a sua redistribuição pelo floema, das folhas mais velhas para as mais novas, para as regiões de crescimento e para os frutos em desenvolvimento (MALAVOLTA, 1980; MENGEL \& KIRBY, 1987).

O potássio é importante para a ativação de inúmeras enzimas, que participam em diversas fases do metabolismo como reações de fosforilação, síntese de carboidratos, respiração e síntese de proteínas. O potássio também desempenha funções na abertura e fechamento dos estômatos, transporte de carboidratos, fotossíntese, transpiração, divisão celular e qualidade de produtos agrícolas. $O$ potássio não possui função 
estrutural na vida das plantas e não faz parte de compostos orgânicos constituintes dos vegetais, como celulose, amido, proteínas, gorduras e clorofilas (FERRI, 1985; MARSCHNER, 1986; MALAVOLTA, 1980).

O potássio se redistribui facilmente na planta e os sintomas de carência do elemento se manifestam em primeiro lugar nas folhas mais velhas. A deficiência de potássio em milho é caracterizado pela clorose nas folhas mais velhas, ao mesmo tempo há o aparecimento de uma faixa necrótica nos bordos e ao longo de todo o comprimento da folha e dilaceração de suas margens. Os colmos são finos, apresentando encurtamento dos internódios e o sistema radicular é fraco (MALAVOLTA et al., 1974; MALAVOLTA et al., 1989).

\subsubsection{Cálcio}

O cálcio aparece no solo em minerais primários, carbonatos, sulfatos, adsorvido aos colóides, na matéria orgânica e na solução do solo (MELLO et al., 1989). A absorção de cálcio pelas plantas se dá na forma iônica $\mathrm{Ca}^{+2}$, no ápice das paredes celulares da endoderme de raízes ainda não suberizadas (CLARKSON \& SANDERSON, 1978), sendo o transporte da maior parte do cálcio absorvido no xilema unidirecional, através de reações de troca com outros cátions em vasos condutores (MALAVOLTA, 1980). 
A maior proporção do cálcio na planta encontra-se em formas não solúveis em água e sua localização na célula explica em parte a falta de redistribuição em condições de deficiência, aparecendo sintomas de carência em órgãos e partes mais novas (MALAVOLTA, 1980).

Entre as funções do cálcio destaca-se a de ser integrante da parede celular, onde forma pectatos na lamela média, aumentando a rigidez da parede. O cálcio é ativador de diversas enzimas e participa na manutenção da integridade da membrana citoplasmática aos íons absorvidos (FERRI, 1985). No seu papel na absorção iônica, o cálcio se combina a grupos fosfatos da fração lipídica da membrana plasmática ou satisfaz sítios aniônicos da fração proteica da membrana, provocando diminuição na sua permeabilidade à passagem de ions (CALDWELL \& HAUG, 1982).

O cálcio é um elemento não móvel nas plantas, não sendo transportado pelo floema (RAIJ, 1991). Sintomas de deficiência deste elemento manifestam-se em pontos de crescimento, particularmente da raiz, onde aparecem núcleos poliplóides, células binucleadas, núcleos constritos e divisões amitóticas; o desenvolvimento da raiz cessa e morre quando a deficiência é severa (EPSTEIN, 1975; MALAVOLTA, 1980). As pontas das folhas mais novas em desenvolvimento gelatinizam e, quando secas, grudam umas às outras. Nas folhas superiores aparecem, sucessivamente, amarelecimento, secamento, necrose e dilaceração das margens e clorose internerval (MALAVOLTA \& DANTAS, 1987). 


\subsubsection{Magnésio}

O magnésio no solo existe nas formas de minerais primários, carbonatos, como constituinte da rede cristalina de algumas argilas, fixado na matéria orgânica, adsorvido à fração coloidal e na solução do solo (MELLO et al., 1989).

$\mathrm{O}$ magnésio é absorvido pelas plantas na forma de $\mathrm{Mg}^{+2}$. O íon $\mathrm{Mg}$ absorvido pelas raízes se move para cima na corrente transpiratória; o $\mathrm{Mg}^{+2}$ é móvel no floema e pode ser translocado das folhas mais velhas para as mais novas ou para os frutos (MALAVOLTA, 1980).

Nos tecidos da planta, ânions minerais e orgânicos como malato e citrato, estão associados ao $\mathrm{Mg}$, representando cerca de $70 \%$ do teor total de $\mathrm{Mg}$. $\mathrm{O} \mathrm{Mg}$ também pode estar associado com ânions não difusíveis como oxalato e pectato (MENGEL \& KIRBY, 1987).

O magnésio participa na formação de clorofila, representando $2,7 \%$ do seu peso molecular, atua como ativador de numerosas enzimas, incluindo as enzimas fosforilativas relacionadas com o metabolismo energético, inclusive as enzimas ativadoras de aminoácidos, que catalizam o primeiro passo da síntese protéica (FERRI, 1985).

Dada a mobilidade do magnésio no floema, os sintomas de carência manifestam-se em primeiro lugar nas folhas mais velhas (FERRI, 1985). 
Deficiências de magnésio manifestam-se através de sintomas nas folhas velhas, as regiões internervais começam a se tornar cloróticas ao longo de todo o comprimento da folha permanecendo verde somente as nervuras, o sintoma progride para as folhas mais novas (MALAVOLTA et al., 1974; MALAVOLTA \& DANTAS, 1987).

\subsubsection{Enxofre}

O enxofre no solo ocorre na forma orgânica, chegando a constituir quase $100 \%$ do S total, participando das proteínas, aminoácidos, pepitídios e tiocianatos (MELLO et al., 1989). A fração mineral do enxofre no solo, de menos de $5 \%$ do total, em condições aeróbicas se encontra como sulfato, e em condições anaeróbicas, de solo mal arejado, como sulfeto, podendo haver desprendimento de $\mathrm{H}_{2} \mathrm{~S}$ do solo ou até formação de enxofre elementar (RAIJ, 1991).

$\mathrm{O} \mathrm{SO}_{2}$ existente na atmosfera, proveniente da queima de combustíveis fósseis e da poluição industrial, é uma fonte importante de enxofre no solo. $\mathrm{O} \mathrm{SO}_{2}$ do ar é em parte oxidado, dando o $\mathrm{SO}_{4}^{-2}$ que é trazido ao solo pelas chuvas (MALAVOLTA, 1980; RAIJ, 1991).

O S é absorvido pelas plantas predominantemente como íon $\mathrm{SO}_{4}{ }^{-2}$.

$\mathrm{O}$ contato do $\mathrm{SO}_{4}{ }^{-2}$ com a raiz se faz principalmente por fluxo de massa e o processo de absorção é ativo. O sulfato é transportado preferencialmente na direção acrópeta, da base da planta para cima, sendo muito pequena a capacidade da planta para mover o enxofre na direção basípeta (MALAVOLTA, 1980). 
O enxofre é componente de alguns aminoácidos e de todas as proteínas vegetais. O enxofre é importante como grupo ativo de enzimas e de coenzimas, na fotossíntese participa da síntese de clorofila, da absorção de $\mathrm{CO}_{2}$, da atividade da carboxilase de ribulose $-2 \mathrm{P}$ e de reações de fosforilação e é essencial na fixação de $\mathrm{N}_{2}$ pelas leguminosas nodulares (FERRI, 1985).

O enxofre é pouco móvel no floema, em caso de carência do elemento, os sintomas de deficiência aparecem em primeiro lugar nos órgãos mais novos (FERRI, 1985; MALAVOLTA, 1990), sendo que as folhas novas, tornam-se amareladas (MALAVOLTA et al., 1989). 


\section{MATERIAL E MÉTODOS}

\subsection{Localização do Experimento}

O experimento foi conduzido no período de agosto a novembro de 1993, em condições de casa de vegetação pertencente ao Departamento de Ciência do Solo da Escola Superior de Agricultura "Luiz de Queiroz", Campus de Piracicaba, USP, localizado a $22^{\circ}$ e $42^{\prime}$ e $30^{\prime \prime}$ de latitude sul e $47^{\circ}$ e $38^{\prime}$ e $60^{\prime}$ de longitude oeste e altitude média de $576 \mathrm{~m}$.

\subsection{Coleta e Preparo da Amostra}

Como substrato foram utilizadas frações de um lote de terra da camada superficial, retiradas a uma profundidade de 0 a $20 \mathrm{~cm}$ de um solo de baixa fertilidade e com acidez elevada, coletadas no município de Piracicaba, Estado de São Paulo, classificado como Areia Quartzosa.

A amostra de solo após coletada, foi seca ao ar e passada em peneira de $2 \mathrm{~mm}$ de abertura de malha, homogeneizada e subamostrada para as análises de fertilidade do 
solo, de rotina. A amostra de solo homogeneizada foi utilizada para enchimento dos vasos de barro revestidos internamente com neutrol.

\subsection{Caracterização Química do Substrato}

A amostra de solo do lote de terra coletado foi submetida às seguintes análises químicas, segundo metodologia preconizada pelo Instituto Agronômico de Campinas, Estado de São Paulo.

- pH em solução centimolar de $\mathrm{CaCl}_{2}$, determinado por potenciometria na relação solosolução de 1:2,5.

- matéria orgânica segundo o método descrito por QUAGGIO \& RAIJ (1979).

- fósforo disponível extraído com resina trocadora de ânions e dosado por fotocolorimetria.

- potássio trocável, extraído com resina trocadora de cátions e dosado por fotometria de chama. 
- cálcio e magnésio trocáveis, extraídos com resina trocadora de cátions e dosados por espectrofotometria de absorção atômica.

- acidez titulável $(\mathrm{H}+\mathrm{Al})$ determinada pela solução tampão SMP de SHOEMAKER et al. (1961) pH 7,5.

As características químicas do solo utilizado no experimento encontram-se no Quadro 1.

Quadro 1 - Características químicas da amostra de terra, coletada na camada de 0 - 20 cm de profundidade, utilizada no Experimento ${ }^{1}$.

\begin{tabular}{|c|c|c|c|c|c|}
\hline $\mathrm{pH}$ & & $\%$ & $\mu \mathrm{g} . \mathrm{cm}^{-3}$ & & meq. $100 \mathrm{~cm}^{-3}$ \\
\hline $\mathrm{CaCl}_{2}$ & & M.O. & $\mathrm{P}$ & & $\mathrm{H}+\mathrm{Al}$ \\
\hline \multirow[t]{2}{*}{3,9} & & 1,1 & 3 & & 3,1 \\
\hline & \multicolumn{2}{|r|}{ meq. $100 \mathrm{~cm}^{-3}$} & & & $\%$ \\
\hline $\mathrm{K}$ & $\mathrm{Ca}$ & $\mathrm{Mg}$ & SB & $\mathrm{T}$ & V \\
\hline 0,04 & 0,8 & 0,4 & 1,24 & 4,34 & 28,57 \\
\hline
\end{tabular}

${ }^{1}$ Análises realizadas no Laboratório de Fertilidade do Solo do Departamento de Ciência do Solo da ESALQ/USP-SP. 


\subsection{Tratamentos}

Os tratamentos consistiram das combinações de quatro relações $\mathrm{Ca}: \mathrm{Mg}$ no solo, dois níveis de saturação por bases e três níveis de fósforo.

Para se obter as relações Ca:Mg e os níveis de saturação pretendidos, levou-se em conta os teores de $\mathrm{Ca}$ e $\mathrm{Mg}$ original da amostra de solo e adicionou-se $\mathrm{CaCO}_{3}$ e MgO puros (p.a.) com base em equivalente miligrama. O Quadro 2 apresenta as fontes e doses adicionadas ao solo nos diferentes tratamentos e as relações $\mathrm{Ca}: \mathrm{Mg}$ estabelecidas nos sais.

A adubação fosfatada foi feita, utilizando como fonte de $\mathrm{P}$, o fosfato monoamônico (MAP), com 53,5\% de $\mathrm{P}_{2} \mathrm{O}_{5}$.

\subsection{Delineamento Experimental e Análise Estatística}

O delineamento experimental adotado foi inteiramente casualizado, num esquema fatorial $4 \times 2 \times 3$, sendo constituído de quatro relações Ca: $\mathrm{Mg}(2: 1,3: 1,4: 1$, 5:1), dois níveis de saturação por bases $(50$ e $70 \%)$ e três níveis de fósforo $(0,100$ e 200 ppm), envolvendo 24 tratamentos, que com as quatro repetições totalizaram 96 vasos. A unidade experimental consistiu de um vaso com capacidade para $3 \mathrm{dm}^{3}$ de solo.

A análise estatística dos resultados foi feita utilizando o pacote estatístico SANEST, com significância pelo teste $\mathrm{F}$ aos níveis de 1 e $5 \%$ de probabilidade, segundo GOMES (1990). 
Quando constatava-se efeito significativo pelo teste F para determinada causa de variação, efetuou-se seu desdobramento para regressão linear e quadrática, utilizando o teste $\mathrm{F}$ e o coeficiente de determinação para escolher a regressão que melhor se ajustasse aos resultados.

Quadro 2 - Quantidades de cálcio e magnésio adicionadas ao solo estudado em diferentes relações Ca:Mg estabelecidas nos sais.

\begin{tabular}{|c|c|c|c|c|c|}
\hline \multirow{2}{*}{$\begin{array}{l}\% \\
\mathrm{~V}\end{array}$} & \multirow[b]{2}{*}{$\mathrm{Ca}: \mathrm{Mg}$} & \multicolumn{2}{|c|}{$\begin{array}{l}\text { meq. } 100 \mathrm{~cm}^{-3} \\
\text { necessários }\end{array}$} & \multicolumn{2}{|c|}{ Dose aplicada (g vaso $\left.{ }^{-1}\right)$} \\
\hline & & $\mathrm{Ca}$ & $\mathrm{Mg}$ & $\mathrm{CaCO}_{3}$ & $\mathrm{MgO}$ \\
\hline 50 & $2: 1$ & 0,6200 & 0,31 & 0,9300 & 0,1860 \\
\hline 50 & $3: 1$ & 0,7975 & 0,1325 & 1,1963 & 0,0795 \\
\hline 50 & $4: 1$ & 0,9040 & 0,0260 & 1,3560 & 0,0156 \\
\hline 50 & $5: 1$ & 1,2000 & - & 1,8000 & - \\
\hline 70 & $2: 1$ & 1,1987 & 0,5993 & 1,7981 & 0,3596 \\
\hline 70 & $3: 1$ & 1,4485 & 0,3495 & 2,1228 & 0,2097 \\
\hline 70 & $4: 1$ & 1,5984 & 0,1996 & 2,3976 & 0,1198 \\
\hline 70 & $5: 1$ & 1,6983 & 0,0997 & 2,5475 & 0,0598 \\
\hline
\end{tabular}




\subsection{Instalação e Condução do Experimento}

Inicialmente foi determinada a capacidade de retenção de água da amostra de solo escolhido para o experimento, visando manter sempre o teor de umidade do solo em torno de 0,3 bar, pelo método da pesagem.

As amostras de solo correspondentes a cada repetição dos tratamentos foram transferidas para sacos plásticos na quantidade de $3 \mathrm{dm}^{3}$, procedendo à adubação com micronutrientes, conforme especificado no Quadro 3.

$\mathrm{O}$ cálcio e magnésio foram incorporados às porções de $3 \mathrm{dm}^{3}$ de solo, por agitação manual em sacos plásticos, variando-se as quantidades de cada elemento, de acordo com a relação $\mathrm{Ca}: \mathrm{Mg}$ desejada e levando-se em conta os teores desses cátions já contidos no solo.

Após a aplicação dos micronutrientes e dos sais e da homogeneização das amostras, o solo foi recolocado nos respectivos vasos.

A seguir iniciou-se a incubação do solo em casa de vegetação, por um período de 21 dias, mantendo o teor de umidade próximo à 0,3 bar através de pesagens diárias dos vasos.

Após a incubação, o solo de cada vaso foi misturado, submetido à secagem ao ar, até atingir umidade constante. As amostras de solo foram transferidas para sacos plásticos e efetuou-se a incorporação de fósforo de acordo com cada tratamento. As amostras foram bem misturadas e homogeneizadas, retornando em seguida aos vasos. 
Um dia antes do plantio, cada vaso foi umedecido de modo a se obter aproximadamente 0,3 bar.

No dia seguinte foi feita a semeadura de milho híbrido CX 322 colocando-se oito sementes por vaso na profundidade de $3 \mathrm{~cm}$.

Quadro 3 - Quantidades e fontes de micronutrientes utilizados no estudo.

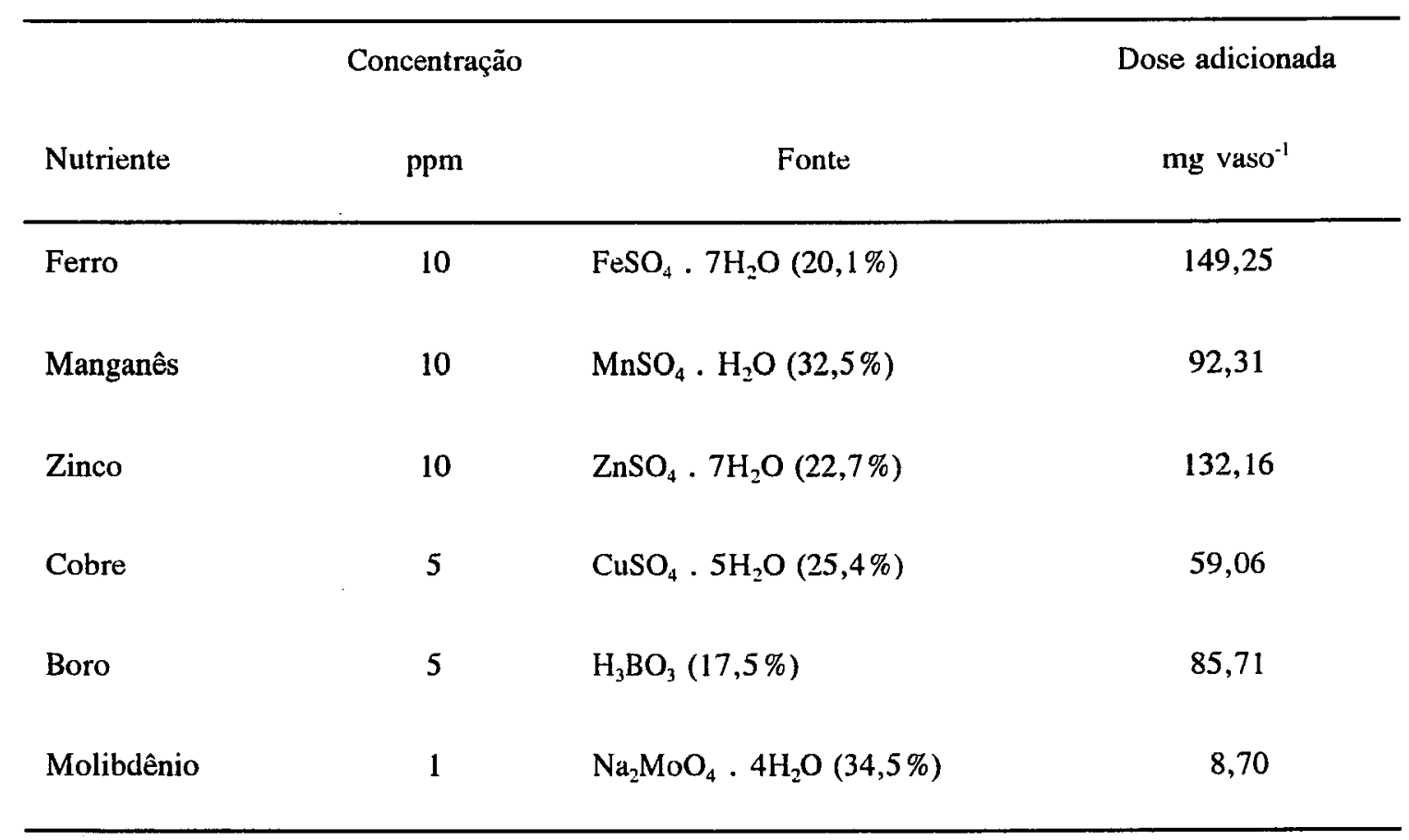




\subsection{Irrigação}

Após o plantio, no controle da irrigação durante a condução do experimento, as plantas recebiam diariamente uma quantidade de água deionizada equivalente àquela evapotranspirada de cada vaso.

\subsection{Desbaste e Adubação em Cobertura}

Aos 4 dias após o plantio, ocorreu o início da germinação, sendo que o desbaste procedeu-se aos 9 dias após o plantio, deixando quatro plantas por vaso.

Aos 10,17 e 39 dias após o plantio, foi realizada a adubação nitrogenada e potássica em cobertura, utilizando, respectivamente, nitrato de amônio $\left(\mathrm{NH}_{4} \mathrm{NO}_{3}\right)$ e cloreto de potássio $(\mathrm{KCl})$.

As doses totais, as fontes das adubações e as formas de aplicação, para cada unidade experimental, foram as seguintes:

$\mathrm{N}$ : $92,72 \mathrm{ppm}$ de $\mathrm{N}$, nos tratamentos em que se omitiu o fósforo, $46,36 \mathrm{ppm}$ de $\mathrm{N}$, nos tratamentos com $100 \mathrm{ppm}$ de $\mathrm{NH}_{4} \mathrm{H}_{2} \mathrm{PO}_{4}$ e não houve cobertura nos tratamentos com $200 \mathrm{ppm}$ de $\mathrm{NH}_{4} \mathrm{H}_{2} \mathrm{PO}_{4}$. O Nitrogênio foi aplicado em solução 10 dias após o plantio na forma de $\mathrm{NH}_{4} \mathrm{NO}_{3}$. Aos 17 e 39 dias após o plantio foram feitas a segunda e terceira adubações nitrogenadas em cobertura, utilizando $\mathrm{NH}_{4} \mathrm{NO}_{3}$ como fonte, à base de 100 ppm para cada aplicação: 
K: 100 ppm de K, aplicado em cobertura, 10 e 39 dias após o plantio, na forma de $\mathrm{KCl}$ em solução.

\subsection{Colheita das Plantas}

Aos 42 dias após o plantio foi efetuada a colheita da parte aérea das plantas, cortando-se as plantas rente à terra. O material verde foi acondicionado em sacos de papel e submetidos, posteriormente, à secagem em estufa de circulação forçada, com temperatura em torno de $65^{\circ} \mathrm{C}$, até que atingisse peso constante. A parte aérea seca de cada tratamento foi pesada, para se obter a produção da matéria seca e em seguida passada por moinho tipo Willey para se fazer a análise mineral.

\subsection{Análise Química das Plantas}

Os teores totais dos nutrientes presentes no tecido foliar da parte aérea foram determinados da seguinte maneira:

- o teor de nitrogênio total foi determinado pelo método do semimicro Kjedahl, depois da digestão sulfúrica de $100 \mathrm{mg}$ de matéria seca, destilação com soda $20 \%$ e dosagem com $\mathrm{H}_{2} \mathrm{SO}_{4} 0,05 \mathrm{~N}$. 
- o fósforo, cálcio, magnésio, potássio e enxofre, pela digestão nitro-perclórica de 500 mg de matéria seca. No extrato obtido, foram dosados o fósforo total pelo método fotocolorimétrico de molibdato-vanadato, cálcio, magnésio e potássio por espectrofotometria de absorção atômica, enxofre por turbidimetria do sulfato de bário

e determinado por fotocolorimetria (MALAVOLTA et al., 1989; SARRUGE \& HAAG, 1974).

\subsection{Parâmetros Avaliados}

Matéria seca da parte aérea da planta.

Teor e acumulação de nitrogênio, fósforo, potássio, cálcio, magnésio e enxofre na parte aérea das plantas.

Com base nos dados de produção de matéria seca da parte aérea e dos seus teores de $\mathrm{N}, \mathrm{P}, \mathrm{K}, \mathrm{Ca}, \mathrm{Mg}$ e $\mathrm{S}$, foi determinada a quantidade desses nutrientes, acumulada na parte aérea das plantas. 


\section{4 - RESULTADOS E DISCUSSÃO}

\section{Crescimento e nutrição mineral do milho}

Os valores relativos à matéria seca, quantidade acumulada e teores de $\mathrm{N}, \mathrm{P}, \mathrm{K}$, Ca, Mg e S na parte aérea do milho aparecem nos Quadros 4 e 5 .

\section{Produção de matéria seca}

As análises de variância dos dados mostraram que as saturações por bases, relações Ca:Mg no solo, doses de $\mathrm{P}$ testadas e suas interações influenciaram significativamente ao nível de $1 \%$, sobre a produção de matéria seca do milho utilizado (Quadro 6).

Houve uma resposta crescente na produção de matéria seca, à medida que a saturação foi aumentada (Quadro 7). 


$$
\begin{aligned}
& \stackrel{n}{m}
\end{aligned}
$$

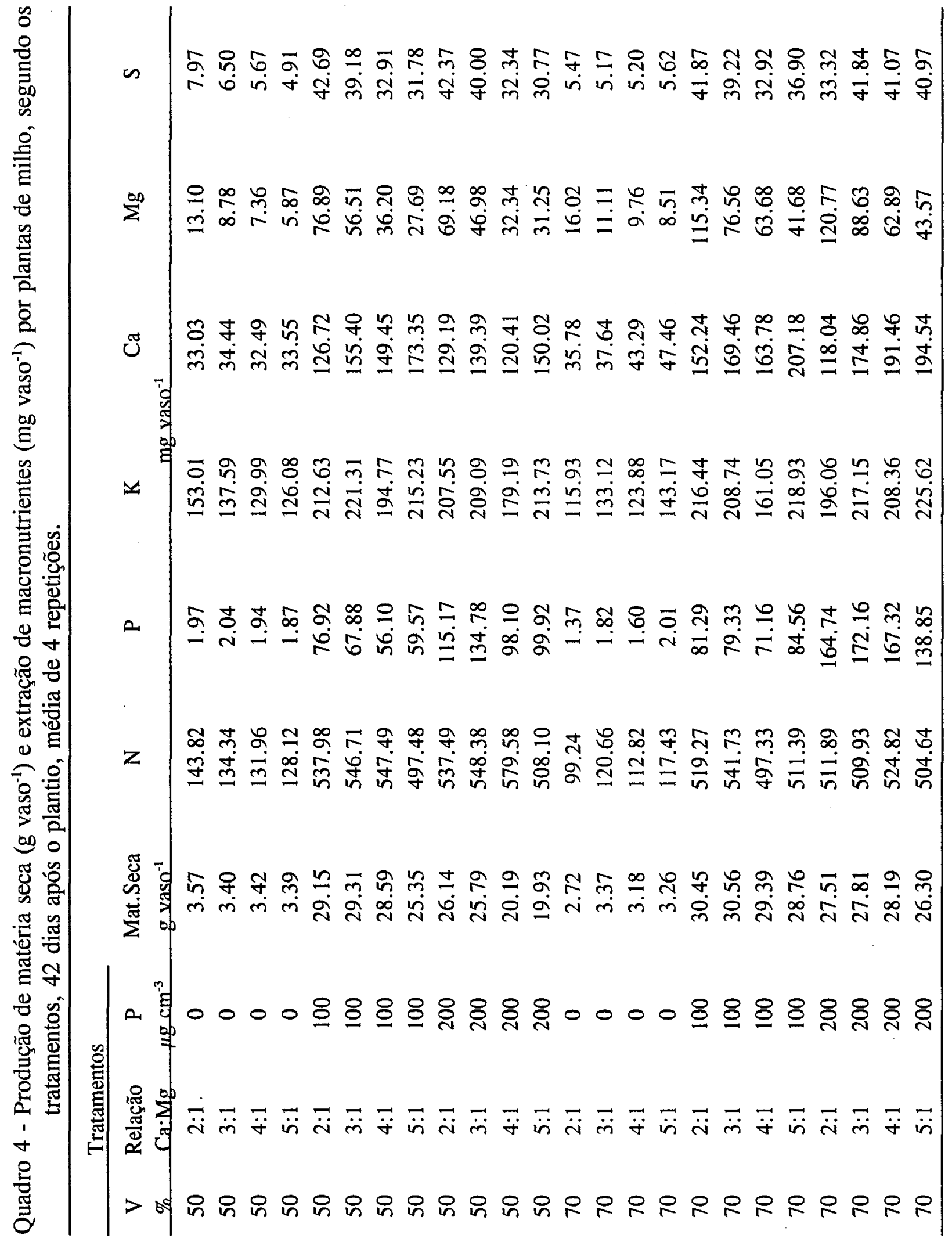


Quadro 5 - $\quad$ Teores de macronutrientes (\%) encontrados na matéria seca da parte aérea das plantas de milho, segundo os tratamentos, 42 dias após o plantio, média de 4 repetições.

\begin{tabular}{|c|c|c|c|c|c|c|c|c|}
\hline \multicolumn{3}{|c|}{ Tratamentos } & \multirow[b]{2}{*}{$\mathrm{N}$} & \multirow[b]{2}{*}{$\mathrm{P}$} & \multirow[b]{2}{*}{$\mathrm{K}$} & \multirow[b]{2}{*}{$\mathrm{Ca}$} & \multirow[b]{2}{*}{$\mathrm{Mg}$} & \multirow[b]{2}{*}{$S$} \\
\hline $\mathrm{V}$ & Relação & $\mathrm{P}$ & & & & & & \\
\hline$\%$ & Ca:Mg & $\mu \mathrm{g} \mathrm{cm}^{-3}$ & $\ldots$. & n...... & .......... \% & 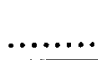 & $\ldots \ldots \ldots$ & $\ldots \ldots$ \\
\hline 50 & $2: 1$ & 0 & 4.02 & 0.05 & 4.28 & 0.92 & 0.36 & 0.22 \\
\hline 50 & $3: 1$ & 0 & 3.92 & 0.06 & 4.04 & 1.00 & 0.25 & 0.18 \\
\hline 50 & $4: 1$ & 0 & 3.87 & 0.05 & 3.82 & 0.94 & 0.21 & 0.16 \\
\hline 50 & $5: 1$ & 0 & 3.78 & 0.05 & 3.71 & 0.97 & 0.17 & 0.14 \\
\hline 50 & $2: 1$ & 100 & 1.84 & 0.26 & 0.72 & 0.43 & 0.26 & 0.14 \\
\hline 50 & $3: 1$ & 100 & 1.86 & 0.23 & 0.75 & 0.53 & 0.19 & 0.13 \\
\hline 50 & $4: 1$ & 100 & 1.91 & 0.19 & 0.68 & 0.52 & 0.12 & 0.11 \\
\hline 50 & $5: 1$ & 100 & 1.96 & 0.23 & 0.84 & 0.68 & 0.10 & 0.12 \\
\hline 50 & $2: 1$ & 200 & 2.06 & 0.44 & 0.79 & 0.49 & 0.26 & 0.16 \\
\hline 50 & $3: 1$ & 200 & 2.12 & 0.52 & 0.81 & 0.54 & 0.18 & 0.15 \\
\hline 50 & $4: 1$ & 200 & 2.87 & 0.48 & 0.88 & 0.59 & 0.16 & 0.16 \\
\hline 50 & $5: 1$ & 200 & 2.55 & 0.50 & 1.07 & 0.75 & 0.15 & 0.15 \\
\hline 70 & $2: 1$ & 0 & 3.64 & 0.05 & 4.24 & 1.32 & 0.58 & 0.20 \\
\hline 70 & $3: 1$ & 0 & 3.57 & 0.05 & 3.93 & 1.12 & 0.32 & 0.15 \\
\hline 70 & $4: 1$ & 0 & 3.55 & 0.05 & 3.90 & 1.38 & 0.30 & 0.16 \\
\hline 70 & $5: 1$ & 0 & 3.59 & 0.06 & 4.38 & 1.45 & 0.26 & 0.17 \\
\hline 70 & $2: 1$ & 100 & 1.70 & 0.26 & 0.71 & 0.5 & 0.37 & 0.13 \\
\hline 70 & $3: 1$ & 100 & 1.77 & 0.25 & 0.68 & 0.55 & 0.25 & 0.12 \\
\hline 70 & $4: 1$ & 100 & 1.69 & 0.24 & 0.54 & 0.55 & 0.21 & 0.11 \\
\hline 70 & $5: 1$ & 100 & 1.77 & 0.29 & 0.76 & 0.71 & 0.14 & 0.12 \\
\hline 70 & $2: 1$ & 200 & 1.86 & 0.59 & 0.71 & 0.42 & 0.43 & 0.12 \\
\hline 70 & $3: 1$ & 200 & 1.83 & 0.61 & 0.78 & 0.62 & 0.31 & 0.15 \\
\hline 70 & $4: 1$ & 200 & 1.85 & 0.59 & 0.73 & 0.68 & 0.22 & 0.14 \\
\hline 70 & $5: 1$ & 200 & 1.91 & 0.52 & 0.85 & 0.74 & 0.16 & 0.15 \\
\hline
\end{tabular}




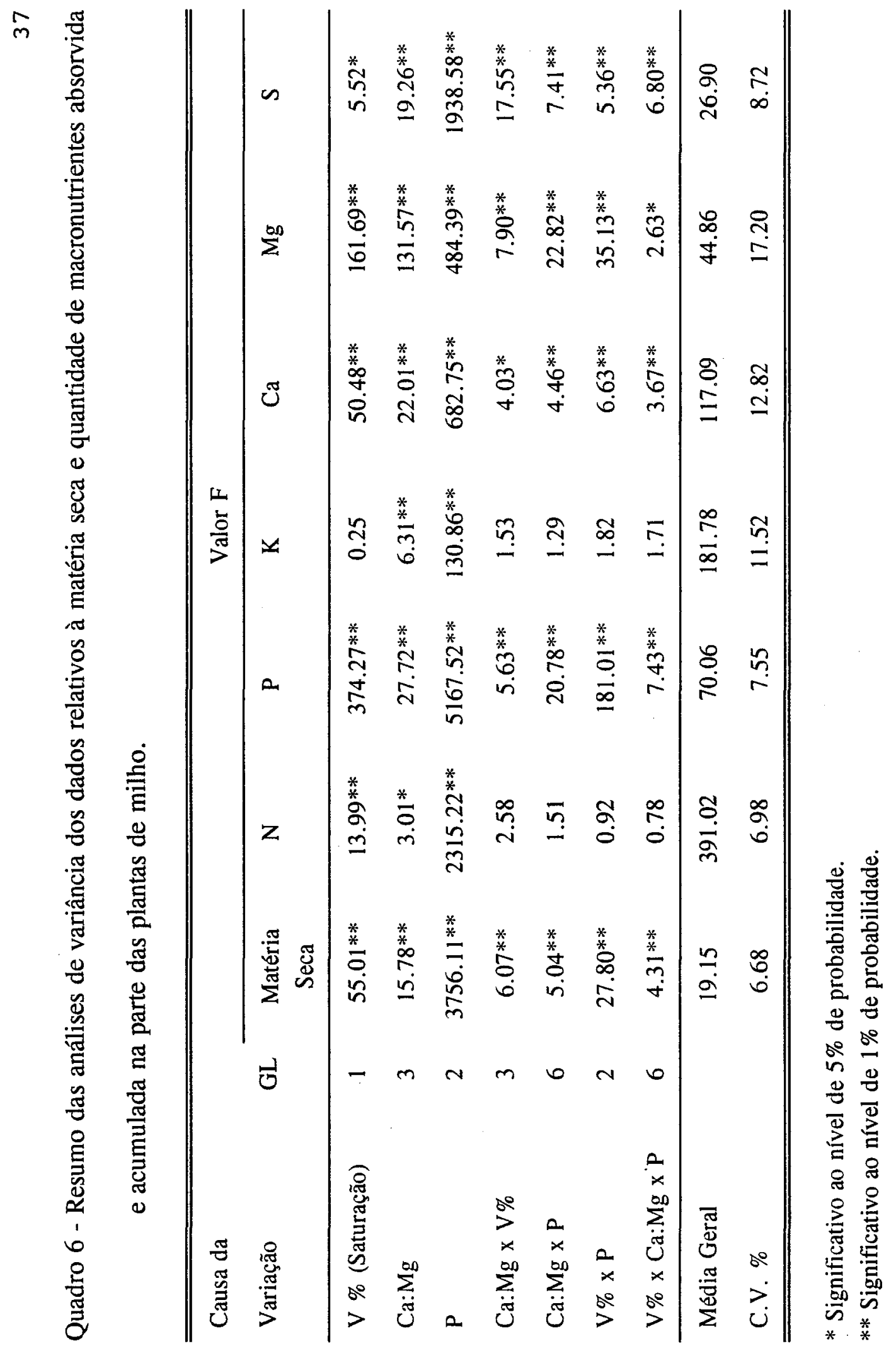




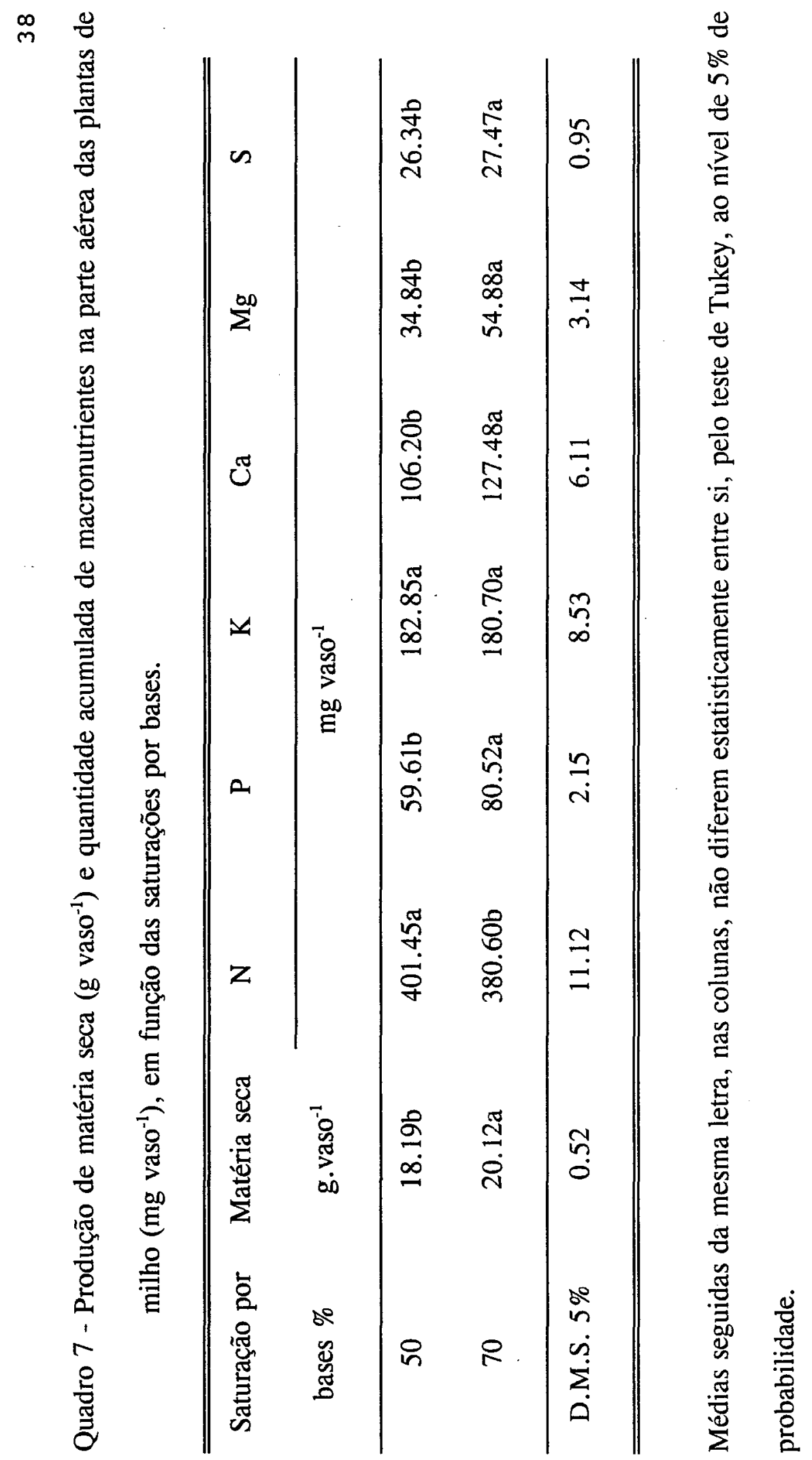


Com o aumento da saturação por bases, foram acrescentadas quantidades maiores de $\mathrm{Ca}$ e $\mathrm{Mg}$ ao solo, em consequência, ocorreram aumentos no crescimento das plantas e maior produção de matéria seca. Os resultados do presente trabalho corroboram àqueles de ARANTES (1983) e CARMELLO (1989).

A produção total de matéria seca foi influenciada pelas relações $\mathrm{Ca}: \mathrm{Mg}$ do solo (Quadro 8). A relação Ca:Mg 3:1 mostrou maiores médias de produção. Aumentando a relação Ca:Mg no solo, nota-se decréscimos na produção de matéria seca das plantas. Tal efeito depressivo nos rendimentos parece estar ligado a distúrbios nutricionais na planta, principalmente àqueles induzidos por relaçōes catiônicas desfavoráveis no solo. A absorção pelas plantas depende da atividade dos íons na solução e nos sítios de troca (ROSOLEM et al., 1984). Na absorção, o Mg e o Ca comportam-se de modo competitivo, o antagonismo implica que o excesso de um desses elementos resulta na diminuição na absorção do outro (EPSTEIN, 1975) dando como resultado, quedas no crescimento e na produção (ROSOLEM et al., 1984). Os baixos teores de $\mathrm{Mg}$ no solo, em associação ao desequilíbrio Ca: $\mathrm{Mg}$ no solo, provocado pelos corretivos com alta proporção de $\mathrm{Ca}$ (alta relação $\mathrm{Ca}: \mathrm{Mg}$ ), causaram decréscimos na produção devido possivelmente à deficiência de magnésio induzida, embora sintomas de deficiência nas plantas não tenham sido observados. 


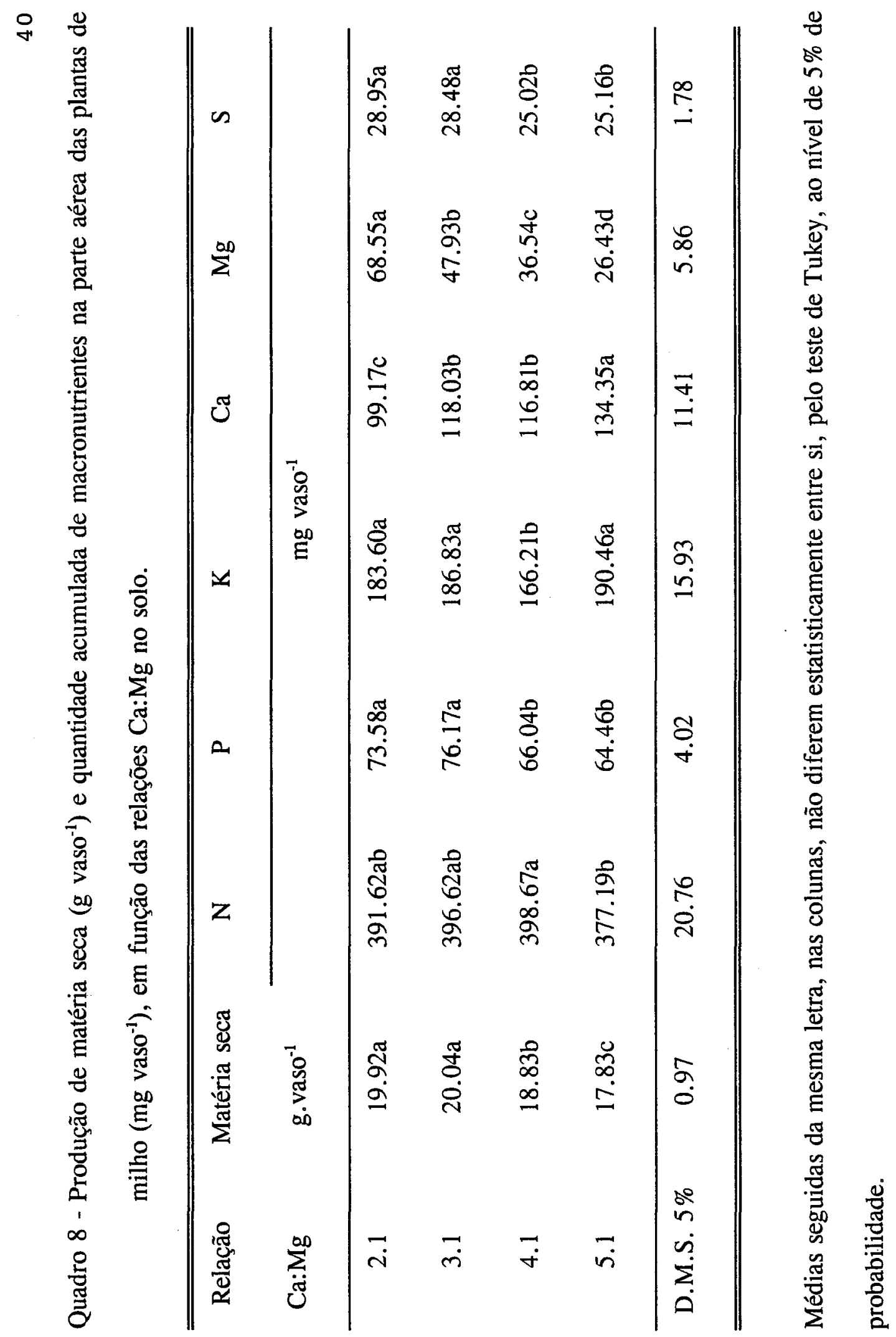


As pesquisas têm mostrado decréscimos na produção de matéria seca de plantas, com incrementos na relação Ca:Mg. Em plantas de milho, ARANTES (1983) notou que relações $\mathrm{Ca}: \mathrm{Mg}$ maiores de 5:1 estabelecidas com o corretivo com o qual a saturação por bases se elevou até $60 \%$, provocaram redução na matéria seca. SFREDO (1976) encontrou que o equilíbrio Ca: $\mathrm{Mg}$ no corretivo, deve ser maior que $1: 1$ e a relação $\mathrm{Ca}: \mathrm{Mg}$ no solo maior que $0.5: 1$ para que a produção de sorgo não seja prejudicada. SOARES et al. (1983), avaliando a influência de relações Ca:Mg (5:1 e 10:1) sobre a produção de matéria seca e a absorção de Ca e Mg em plantas de soja, observaram redução na produção de matéria seca, com acréscimos na proporção de Ca no corretivo. CARMELLO (1989) trabalhando com várias relações Ca:Mg (1:4, 2:3, $3: 2,4: 1)$, observou-se uma ligeira tendência de redução na produção da matéria seca de milho, quando aumentou essa relação.

MARUN (1990) conduzindo experimento com gramíneas forrageiras, observou que aumentos nas relações $\mathrm{Ca}: \mathrm{Mg}$ no solo, provocados pelos corretivos, causaram decréscimo na produção de matéria seca. KURIHARA (1991) estudando diferentes relações Ca:Mg no corretivo (1:2, 5:1, 10:1, 20:1, 40:1), na produção de matéria seca da soja, notou redução nos rendimentos de folhas, caule e parte aérea com aumentos na relação Ca:Mg no corretivo.

Devem-se considerar as funções metabólicas e/ou estruturais do Mg na planta, sua deficiência pode provocar perturbações no metabolismo, com efeitos depressivos no crescimento das plantas (FERRI, 1985, MARSCHNER, 1986). 
Outro fator que se mostrou significativo sobre a produção de matéria seca na parte aérea das plantas foram as doses de P aplicadas (Quadro 9). Houve uma resposta expressiva na produção de matéria seca do milho à adubação fosfatada, com um melhor rendimento quando da aplicação da dose de 100 ppm de $\mathrm{P}$, em relação às doses de 0 e 200 ppm de P. Acréscimos na produção de matéria seca pela aplicação de fósforo foram observados por CRAVO (1984), SHERCHAND \& WHITNEY (1985), BRIENZA (1988), SIMARD et al. (1988), PECK \& MacDONALD (1989).

Avaliando o efeito das relações $\mathrm{Ca}: \mathrm{Mg}$ dentro das respectivas saturaçōes por bases (Quadro 10) verifica-se que a influência foi significativa para a saturação por bases de $50 \%$. A saturação por bases de $50 \%$ mostrou-se mais eficiente nas relações Ca:Mg 2:1 e 3:1, as quais não diferiram entre si. Entretanto, na saturação por bases de $70 \%$, embora as diferenças não tenham sido estatisticamente sig-nificativas, uma maior produção de matéria seca foi atingida com a relação Ca:Mg 3:1.

$\mathrm{O}$ efeito negativo ou depressivo na produção à medida em que aumenta a proporção de Ca no corretivo, provavelmente ocorreu por um desbalanço de cátions, devido a uma reduzida proporção de $\mathrm{Mg}$ no corretivo (alta relação $\mathrm{Ca}: \mathrm{Mg}$ ), comprometendo o crescimento das plantas. Os corretivos tem efeito direto na produção de matéria seca, além de proporcionar $\mathrm{Ca}$ e $\mathrm{Mg}$ aos solos, favorecem o crescimento das raízes, facilitando a absorção de nutrientes, entretanto, deve-se considerar o efeito dos corretivos sobre a CTC, precisa-se de determinadas relações de saturação entre os cátions trocáveis no solo para se promover maior desenvolvimento da parte aérea das plantas. 


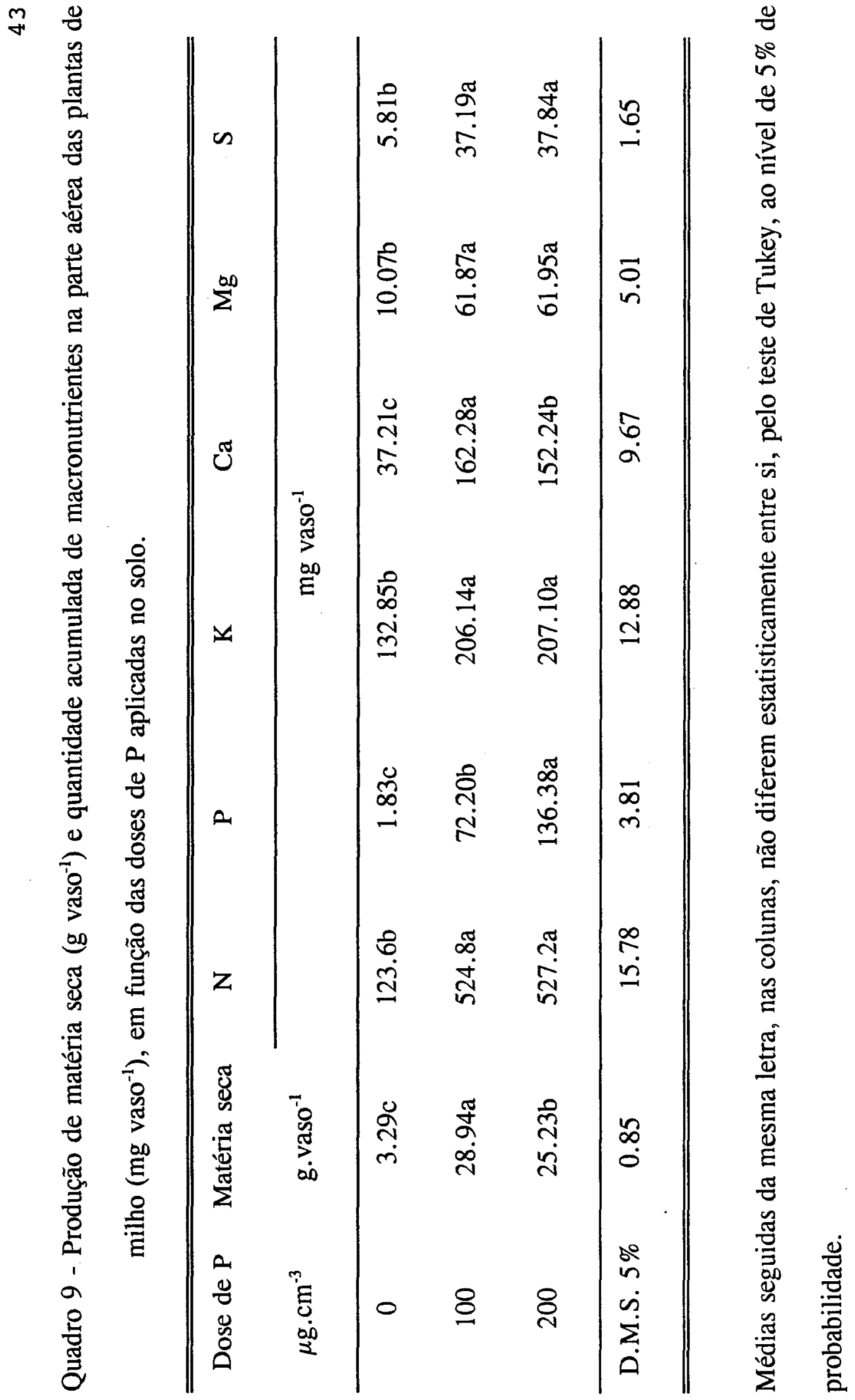


Com relação à participação catiônica na CTC, para estar em sua condição de equilíbrio químico, o solo deve ter no complexo de troca de 60 a $70 \%$ de $\mathrm{Ca}, 15$ a $20 \%$ de $\mathrm{Mg}$ e 3 a 5\% de K (LOPES, 1984; MALAVOLTA, 1989).

Quadro 10 - Produção de matéria seca das plantas de milho ( $\left.\mathrm{g} \mathrm{vaso}^{-1}\right)$, em função das relações Ca:Mg no solo e saturações por bases.

\begin{tabular}{ccc}
\hline Relação & \multicolumn{2}{c}{ Saturação por bases (\%) } \\
\cline { 2 - 3 } Ca:Mg & 50 & 70 \\
\hline $2: 1$ & $19.62 \mathrm{a}$ & $20.23 \mathrm{a}$ \\
$3: 1$ & $19.50 \mathrm{a}$ & $20.58 \mathrm{a}$ \\
$4: 1$ & $17.40 \mathrm{~b}$ & $20.25 \mathrm{a}$ \\
$5: 1$ & $16.22 \mathrm{~b}$ & $19.44 \mathrm{a}$ \\
\hline
\end{tabular}

D.M.S. $5 \%=1.37$

Médias seguidas da mesma letra, nas colunas, não diferem estatisticamente entre si, pelo teste de Tukey, ao nível de $5 \%$ de probabilidade.

Equações de regressão para a produção de matéria seca das plantas de milho sob influência das relações Ca:Mg e das saturações por bases.

$$
\begin{aligned}
& \text { V50: } y=12,478788 x-1,898774 x^{2} R^{2}=0,74^{* *} \\
& \text { V70: } y=12,586872 x-1,782296 x^{2} R^{2}=0,73^{* *}
\end{aligned}
$$


Quanto ao efeito das relações Ca: $\mathrm{Mg}$ dentro de doses de $\mathrm{P}$ na produçã̀o de tecido na parte aérea (Quadro 11), constata-se que a influência não foi significativa para a dose de 0 ppm de P. As doses de 100 e 200 ppm das relações Ca:Mg 3:1 e 2:1 proporcionaram maiores valores de produção, que as das relações $4: 1$ e $5: 1$, sendo que a dose de $100 \mathrm{ppm}$ de $\mathrm{P}$ apresentou uma melhor resposta nos rendimentos da matéria seca. A não existência de efeito significativo das relações $\mathrm{Ca}: \mathrm{Mg}$ sobre a produção de matéria seca na dose de $0 \mathrm{ppm}$ de $\mathrm{P}$, pode ser atribuída ao efeito limitante do fósforo. Esta explicação encontra suporte na ocorrência de sintomas de deficiência de fósforo observados na condução do experimento.

Quadro 11 - Produção de matéria seca das plantas de milho (g vaso-1), em função das relações Ca: $\mathrm{Mg}$ no solo e doses de $\mathrm{P}$ aplicadas.

\begin{tabular}{cccc}
\hline \hline Relação & \multicolumn{3}{c}{ Doses de P $\left(\mu \mathrm{g} \cdot \mathrm{cm}^{-3}\right)$} \\
\cline { 2 - 4 } Ca:Mg & 0 & 100 & 200 \\
\hline $2: 1$ & $3.15 \mathrm{a}$ & $29.80 \mathrm{a}$ & $26.82 \mathrm{a}$ \\
$3: 1$ & $3.38 \mathrm{a}$ & $29.93 \mathrm{a}$ & $26.80 \mathrm{a}$ \\
$4: 1$ & $3.30 \mathrm{a}$ & $28.99 \mathrm{a}$ & $24.19 \mathrm{~b}$ \\
$5: 1$ & $3.33 \mathrm{a}$ & $27.06 \mathrm{~b}$ & $23.11 \mathrm{~b}$ \\
\hline D.M.S. 5\% & 1.68 & & \\
\hline
\end{tabular}

Médias seguidas da mesma letra, nas colunas, não diferem estatisticamente entre si, pelo teste de Tukey, ao nível de $5 \%$ de probabilidade. 
Equações de regressão para as produções de matéria seca em função das relações Ca: $\mathrm{Mg}$ no solo em interação com as doses de $\mathrm{P}$.

$$
\begin{array}{ll}
\text { P0 : } y=1,960075 x-0,265693 x^{2} & R^{2}=0,99 * * \\
\text { P100: } y=18,729771 x-2,726334 x^{2} & R^{2}=0,99 * * \\
\text { P200: } y=16,908643 x-2,529578 x^{2} & R^{2}=0,98^{* *}
\end{array}
$$

Ao avaliar a produção de tecido na parte aérea, em relação às saturações por bases e doses de P aplicadas (Quadro 12), verifica-se influência significativa para as doses de 100 e $200 \mathrm{ppm}$ de P. A dose de $100 \mathrm{ppm}$ de P apresentou os maiores valores de produção, sendo que a saturação por bases de $70 \%$ foi mais eficiente, em relação à saturação por bases de $50 \%$.

O efeito estimulatório do aumento da saturação por bases e do P aplicado, nos valores de produção de matéria seca da parte aérea das plantas de milho, pode-se atribuir ao efeito ocasionado pelos corretivos na elevação do $\mathrm{pH}$, que aumenta a disponibilidade de fósforo. Deve-se destacar, ainda, a importância do Ca no desenvolvimento do sistema radicular (MALAVOLTA, 1980). 
Quadro 12 - Produção de matéria seca das plantas de milho (g vaso-1), em função das saturações por bases e doses de $\mathrm{P}$ aplicadas.

\begin{tabular}{cccc}
\hline Saturação por bases & \multicolumn{3}{c}{ Doses de P $\left(\mu \mathrm{g} \cdot \mathrm{cm}^{-3}\right)$} \\
\cline { 2 - 4 }$\%$ & 0 & 100 & 200 \\
\hline 50 & $3.44 \mathrm{a}$ & $28.10 \mathrm{~b}$ & $23.01 \mathrm{~b}$ \\
70 & $3.13 \mathrm{a}$ & $29.79 \mathrm{a}$ & $27.45 \mathrm{a}$ \\
\hline
\end{tabular}

D.M.S. $5 \%=0.90$

Médias seguidas da mesma letra, nas colunas, não diferem estatisticamente entre si, pelo teste de Tukey, ao nível de $5 \%$ de probabilidade.

Os maiores rendimentos na produção de matéria seca das plantas à aplicação de corretivos e adubação fosfatada tem sido constatada por FERREIRA et al. (1979); KUNISH (1982); HERRERA-ESTRADA (1984); SHERCHAND \& WHITNEY (1985).

Pelo desdobramento da interação saturação por bases x relação $\mathrm{Ca}: \mathrm{Mg} \mathrm{x} \mathrm{P}$, constata-se influência significativa das doses 100 e 200 ppm de P da saturação por bases de 50\% (Quadro 13). As relações Ca:Mg 3:1 e 2:1 mostraram maior produção de matéria seca na parte aérea das plantas, sendo a dose de 100 ppm aquela que mostrou maiores valores de produção de tecido na parte aérea do milho. 
Quadro 13 - Produção de matéria seca das plantas de milho (g vaso-1), em função dos tratamentos.

\begin{tabular}{|c|c|c|c|c|}
\hline \multirow{2}{*}{$\begin{array}{c}\text { Saturação por bases } \\
\%\end{array}$} & \multirow{2}{*}{$\begin{array}{l}\text { Relação } \\
\text { Ca:Mg }\end{array}$} & \multicolumn{3}{|c|}{ Doses de $\mathrm{P}\left(\mu \mathrm{g} \cdot \mathrm{cm}^{-3}\right)$} \\
\hline & & 0 & 100 & 200 \\
\hline \multirow[t]{4}{*}{50} & $2: 1$ & $3.57 \mathrm{a}$ & $29.15 a$ & $26.14 a$ \\
\hline & $3: 1$ & $3.40 \mathrm{a}$ & $29.31 \mathrm{a}$ & $25.79 \mathrm{a}$ \\
\hline & $4: 1$ & $3.42 \mathrm{a}$ & $28.59 \mathrm{a}$ & $20.19 b$ \\
\hline & $5: 1$ & $3.39 \mathrm{a}$ & $25.35 \mathrm{~b}$ & $19.93 b$ \\
\hline \multirow[t]{4}{*}{70} & $2: 1$ & $2.72 \mathrm{a}$ & $30.45 a$ & $27.51 \mathrm{a}$ \\
\hline & $3: 1$ & $3.37 \mathrm{a}$ & $30.56 a$ & $27.81 \mathrm{a}$ \\
\hline & $4: 1$ & $3.18 \mathrm{a}$ & $29.39 a$ & $28.19 a$ \\
\hline & $5: 1$ & $3.26 \mathrm{a}$ & $28.76 a$ & $26.30 \mathrm{a}$ \\
\hline
\end{tabular}

D.M.S. $5 \%=2.38$

Médias seguidas da mesma letra, nas colunas, não diferem estatisticamente entre si, pelo teste de Tukey, ao nível de $5 \%$ de probabilidade.

Entretanto, verifica-se maior crescimento do milho na saturação por bases de

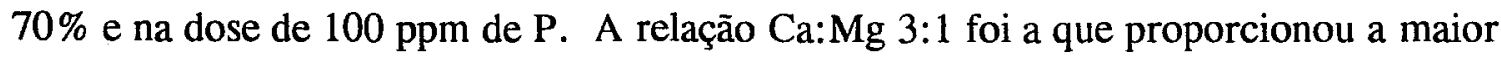


produção de matéria seca, embora não tenham sido constatadas diferenças estatísticas significativas com as outras relações $\mathrm{Ca}: \mathrm{Mg}$ estudadas. Por outra parte, na presença de uma maior dose de $\mathrm{P}$, ocorria um efeito depressivo, o que pode ser atribuído aos efeitos interiônicos. Altos níveis de $\mathrm{P}$ disponível ou a adubação fosfatada podem causar insuficiência de $\mathrm{Zn}$, interação comumente associada com uma queda nos rendimentos (BAUMGARTNER, 1974). Por outro lado, o aumento do teor de $\mathrm{P}$ no solo, pode ter levado a uma fixação de $\mathrm{P}$, o que pode estar relacionado também com um menor crescimento das plantas. O P é um nutriente importante, principalmente nos primeiros períodos da vida da planta, tendo influência no crescimento das raízes (MALAVOLTA, 1980). O aumento do $\mathrm{pH}$ do solo pode levar a um decréscimo na disponibilidade de $\mathrm{P}$ pelo aumento da atividade do Ca (MICHAEL \& ELLIS, 1984), pela precipitação de fosfatos de cálcio insolúveis (HAYNES, 1982) ou pelo acréscimo das reações entre P e Ca (ADAMS \& ODON, 1985).

Com base nos resultados do presente trabalho nos dados de produção de matéria seca, pode-se concluir que se trata de um solo de baixa fertilidade com severas limitações de nutrientes, constatou-se o efeito benéfico da calagem e da adubação fosfatada e confirmou-se a importância da aplicação complementar, como prática nutricional para promover maiores rendimentos no milho. 


\subsection{Concentração mineral e quantidades acumuladas na parte aérea das plantas}

\subsubsection{Teores na parte aérea das plantas e $\mathbf{N}$ absorvido}

No Quadro 14 são apresentados os resultados da análise de variância dos dados do teor de $\mathrm{N}$ na planta. Observa-se que houve efeito significativo ao nível de $5 \%$ para saturações por bases, doses de $\mathrm{P}$ e as interações no teor de $\mathrm{N}$ na parte aérea das plantas.

Observa-se que o incremento da saturação por bases promoveu reduções neste parâmetro (Quadro 15).

Ao avaliar-se o teor de $\mathrm{N}$ na parte aérea das plantas, em relação às doses de $\mathrm{P}$ aplicadas, nota-se que $\mathrm{o}$ aumento dos níveis de $\mathrm{P}$ promoveu uma redução na concentração de $\mathrm{N}$ nas plantas, sendo a dose de $100 \mathrm{ppm}$ de $\mathrm{P}$ aquela que proporcionou o menor teor de $\mathrm{N}$ na parte aérea (Quadro 17 ).

A análise de correlação constatou uma associação negativa do $\mathrm{N}$ com os teores de $\mathrm{P}$ nas plantas $\left(\mathrm{r}=-0,6828^{* *}\right)$. 


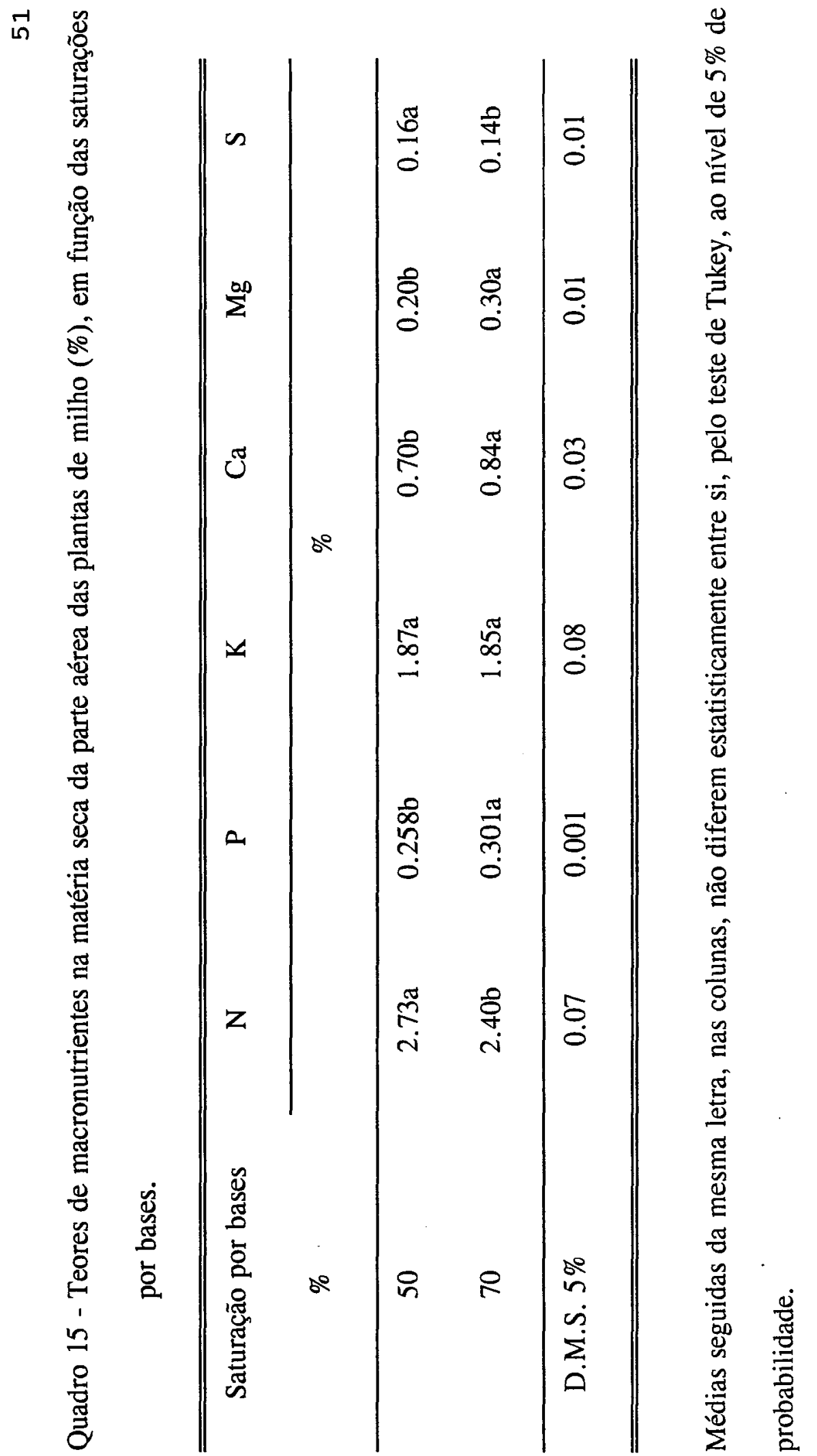




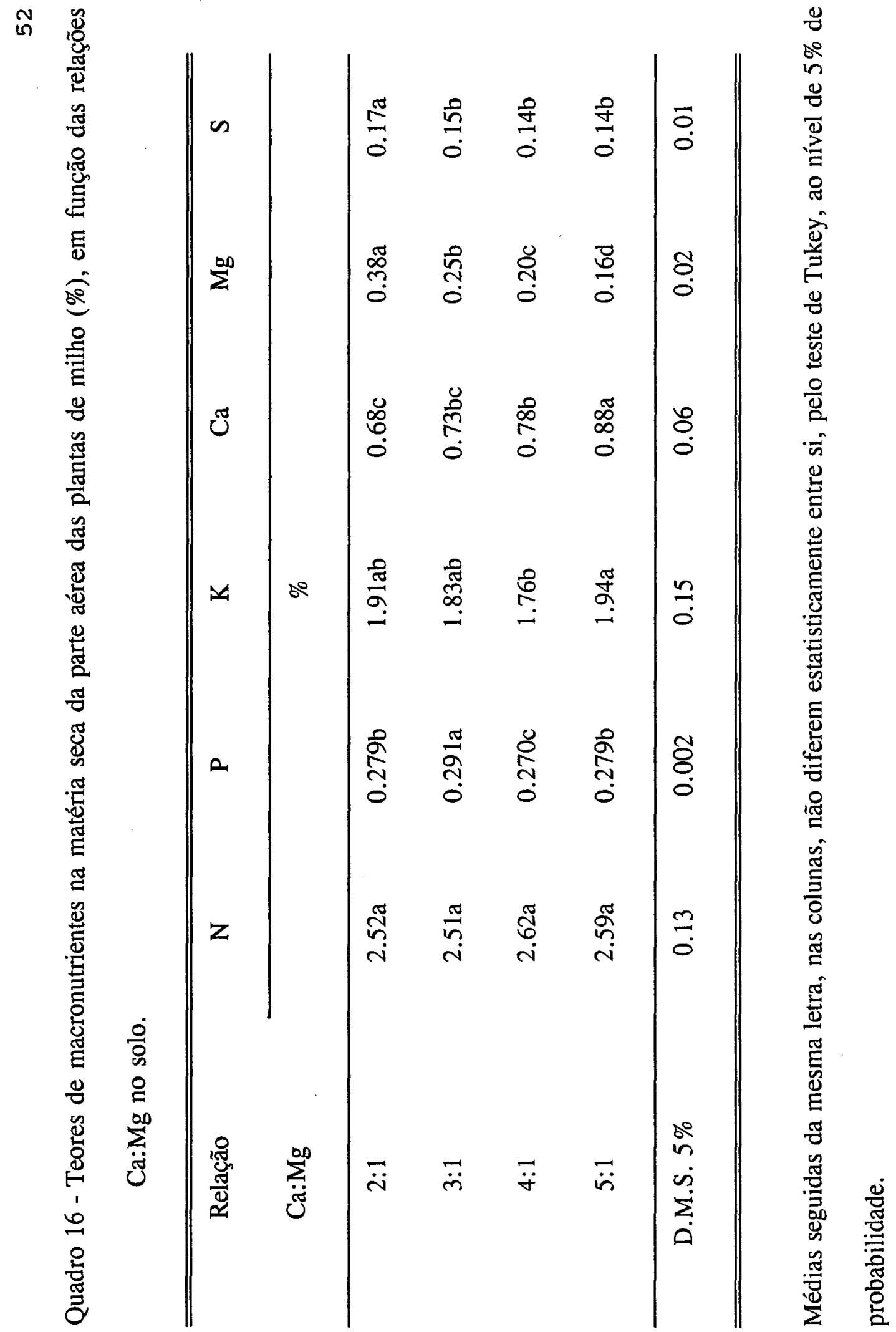


กิ

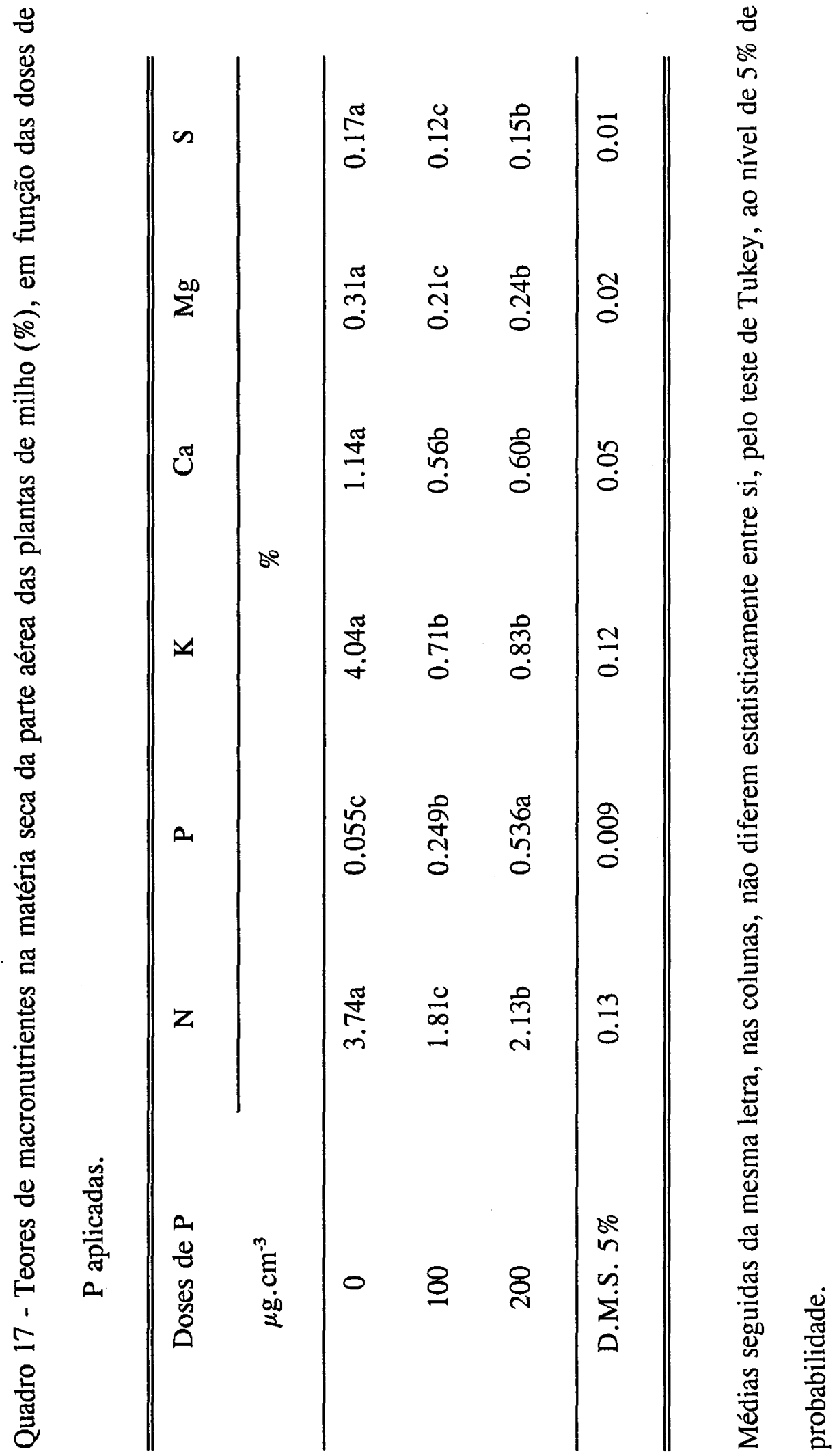


Avaliando o efeito das relações $\mathrm{Ca}: \mathrm{Mg}$ e saturações por bases, evidencia-se a influência significativa, para a saturação por bases de 50\% (Quadro 18). As relações Ca:Mg 4:1 e 5:1 mostraram maior teor de $\mathrm{N}$ no tecido que as relações $2: 1$ e 3:1, as quais não diferiram entre si. KURIHARA (1991) notou uma tendência de aumento no teor de $\mathrm{N}$, à medida que as relações $\mathrm{Ca}: \mathrm{Mg}$ se elevaram. Entretanto, CARMELLO (1989) observou que os teores de $\mathrm{N}$ na parte aérea do milho, diminuiram de forma quadrática, com acréscimos na proporção de Ca no corretivo. OGANGO \& TEYKER (1991) observaram que a concentração de $\mathrm{N}$ em milho foi afetada pela calagem. Os teores de $\mathrm{N}$ nas plantas correlacionaram com os de $\mathrm{Ca}\left(\mathrm{r}=0,7963^{* *}\right)$.

Quadro 18 - Teores de $\mathrm{N}$ na matéria seca da parte aérea das plantas de milho (\%), em função das relações Ca:Mg no solo e saturações por bases.

\begin{tabular}{ccc}
\hline Relação & \multicolumn{2}{c}{ Saturação por bases $(\%)$} \\
\cline { 2 - 3 } Ca:Mg & 50 & 70 \\
\hline $2: 1$ & $2.64 \mathrm{~b}$ & $2.40 \mathrm{a}$ \\
$3: 1$ & $2.63 \mathrm{~b}$ & $2.39 \mathrm{a}$ \\
$4: 1$ & $2.88 \mathrm{a}$ & $2.36 \mathrm{a}$ \\
$5: 1$ & $2.76 \mathrm{ab}$ & $2.43 \mathrm{a}$ \\
\hline
\end{tabular}

D.M.S. $5 \%=0.18$

Médias seguidas da mesma letra, nas colunas, não diferem estatisticamente entre si, pelo teste de Tukey, ao nível de 5\% de probabilidade. 
Quando se analisou o efeito das relações Ca: $\mathrm{Mg}$ e das doses de $\mathrm{P}$, constatou-se uma tendência de redução no teor de $\mathrm{N}$ com o aumento dos níveis de $\mathrm{P}$ aplicados (Quadro 19). Observa-se que na dose de 200 ppm, as relações Ca:Mg apresentaram efeito significativo no teor de $\mathrm{N}$ na parte aérea das plantas, causando acréscimos nas concentrações de $\mathrm{N}$ à medida em que aumenta a relação $\mathrm{Ca}: \mathrm{Mg}$ no corretivo. As relações Ca: $\mathrm{Mg}$ 4:1 e 5:1 conferiram maiores concentrações de $\mathrm{N}$ nas plantas que as relações 2:1 e 3:1, as quais não diferiram entre si. Através da análise de correlação, constata-se ainda, uma associação negativa entre o teor de $\mathrm{N}$ e a matéria seca da parte aérea das plantas $\left(\mathrm{r}=-0,9933^{* *}\right)$, coincidindo a redução na concentração de $\mathrm{N}$ com o aumento no peso seco. Assim, pode-se atribuir a este comportamento um efeito de diluição do $\mathbf{N}$ na parte aérea do milho.

Quadro 19 - Teores de N na matéria seca da parte aérea das plantas de milho (\%), em função das relações $\mathrm{Ca}: \mathrm{Mg}$ no solo e doses de $\mathrm{P}$ aplicadas.

\begin{tabular}{cccc}
\hline Relação & \multicolumn{3}{c}{ Doses de P $\left(\mu \mathrm{g} \cdot \mathrm{cm}^{-3}\right)$} \\
\cline { 2 - 4 } Ca:Mg & 0 & 100 & 200 \\
\hline $2: 1$ & $3.83 \mathrm{a}$ & $1.77 \mathrm{a}$ & $1.96 \mathrm{~b}$ \\
$3: 1$ & $3.75 \mathrm{a}$ & $1.82 \mathrm{a}$ & $1.97 \mathrm{~b}$ \\
$4: 1$ & $3.71 \mathrm{a}$ & $1.80 \mathrm{a}$ & $2.23 \mathrm{a}$ \\
$5: 1$ & $3.68 \mathrm{a}$ & $1.87 \mathrm{a}$ & $2.36 \mathrm{a}$ \\
\hline
\end{tabular}

D.M.S. $5 \%=0.23$

Médias seguidas da mesma letra, nas colunas, não diferem estatisticamente entre si, pelo teste de Tukey, ao nível de $5 \%$ de probabilidade. 
Regressões obtidas para concentração de $\mathrm{N}$ na planta em função das relações Ca:Mg no solo e doses de $\mathrm{P}$ aplicadas.

$$
\begin{array}{ll}
\text { P0 : } y=2,317566 x-0,325523 \mathrm{x}^{2} & \mathrm{R}^{2}=0,99 * * \\
\text { P100: } \mathrm{y}=1,069424 \mathrm{x}-0,143581 \mathrm{x}^{2} & \mathrm{R}^{2}=0,99 * * \\
\text { P200: } \mathrm{y}=1,170680 \mathrm{x}-0,146016 \mathrm{x}^{2} & \mathrm{R}^{2}=0,97 * *
\end{array}
$$

O efeito das saturações por bases e das doses de $\mathbf{P}$ testadas nos teores de $\mathbf{N}$ na parte aérea, mostrou uma redução na concentração de $\mathrm{N}$ com o incremento da dose de $\mathrm{P}$ aplicada, atingindo os valores mínimos na dose de $100 \mathrm{ppm}$ de $\mathrm{P}$ (Quadro 20). Observa-se ainda, que os teores de $\mathrm{N}$ na parte aérea das plantas para a saturação por bases de $70 \%$ foram inferiores àqueles encontrados para a saturação por bases de $50 \%$.

Quadro 20 - Teores de $\mathrm{N}$ na matéria seca da parte aérea das plantas de milho (\%), em função das saturações de bases e doses de $\mathrm{P}$ aplicadas.

\begin{tabular}{cccc}
\hline \hline Saturação por bases & \multicolumn{3}{c}{ Doses de P $\left(\mu \mathrm{g} . \mathrm{cm}^{-3}\right)$} \\
\cline { 2 - 4 }$\%$ & 0 & 100 & 200 \\
\hline 50 & $3.90 \mathrm{a}$ & $1.89 \mathrm{a}$ & $2.40 \mathrm{a}$ \\
70 & $3.59 \mathrm{~b}$ & $1.73 \mathrm{~b}$ & $1.86 \mathrm{~b}$ \\
\hline D.M.S. 5\% & & & \\
\hline \hline
\end{tabular}

Médias seguidas da mesma letra, nas colunas, não diferem estatisticamente entre si, pelo teste de Tukey, ao nível de $5 \%$ de probabilidade. 
No desdobramento da interação saturação por bases x relação Ca: $\mathrm{Mg} \times \mathrm{P}$, verifica-se que a influência foi significativa apenas na saturação por bases de $50 \%$ e na dose de $200 \mathrm{ppm}$ de $\mathrm{P}$ (Quadro 21). As relações 4:1 e 5:1 mostraram maior teor de N nos tecidos que as relações Ca:Mg 2:1 e 3:1, as quais não diferiram entre si ao nível de 5\%. Entretanto, constata-se menor concentração de $\mathrm{N}$ na saturação por bases de $70 \%$ e na dose de $100 \mathrm{ppm}$ de $\mathrm{P}$, sendo a relação Ca:Mg 4:1, aquela que proporcionou menor teor de $\mathrm{N}$ na parte aérea, embora as diferenças não tenham sido estatisticamente significativas. Por outra parte, verifica-se maior concentração de $\mathrm{N}$ na parte aérea das plantas na saturação por bases de $50 \%$ e na dose de $0 \mathrm{ppm}$ de $\mathrm{P}$, com decréscimos à medida em que aumenta a proporção de Ca no corretivo (alta relação de $\mathrm{Ca}: \mathrm{Mg}$ ). 
Quadro 21 - Teores de N na matéria seca da parte aérea das plantas de milho (\%), em função dos tratamentos.

\begin{tabular}{|c|c|c|c|c|}
\hline \multirow{2}{*}{$\begin{array}{c}\text { Saturação por bases } \\
\%\end{array}$} & \multirow{2}{*}{$\begin{array}{l}\text { Relação } \\
\text { Ca:Mg }\end{array}$} & \multicolumn{3}{|c|}{ Doses de $\mathrm{P}\left(\mu \mathrm{g} . \mathrm{cm}^{-3}\right)$} \\
\hline & & 0 & 100 & 200 \\
\hline \multirow[t]{4}{*}{50} & $2: 1$ & $4.02 \mathrm{a}$ & $1.84 \mathrm{a}$ & $2.06 \mathrm{~b}$ \\
\hline & $3: 1$ & $3.92 \mathrm{a}$ & $1.86 \mathrm{a}$ & $2.12 b$ \\
\hline & $4: 1$ & $3.87 \mathrm{a}$ & $1.91 \mathrm{a}$ & $2.87 \mathrm{a}$ \\
\hline & $5: 1$ & $3.78 \mathrm{a}$ & $1.96 \mathrm{a}$ & $2.55 \mathrm{a}$ \\
\hline \multirow[t]{4}{*}{70} & $2: 1$ & $3.64 \mathrm{a}$ & $1.70 \mathrm{a}$ & $1.86 \mathrm{a}$ \\
\hline & $3: 1$ & $3.57 \mathrm{a}$ & $1.77 \mathrm{a}$ & $1.83 \mathrm{a}$ \\
\hline & $4: 1$ & $3.55 \mathrm{a}$ & $1.69 \mathrm{a}$ & $1.85 a$ \\
\hline & $5: 1$ & $3.59 \mathrm{a}$ & $1.77 \mathrm{a}$ & $1.91 \mathrm{a}$ \\
\hline
\end{tabular}

D.M.S. $5 \%=0.32$

Médias seguidas da mesma letra, nas colunas, não diferem estatisticamente entre si, pelo teste de Tukey, ao nivel de $5 \%$ de probabilidade.

As análises de variância para acumulação de $\mathrm{N}$ na parte aérea mostraram efeito significativo das saturações por bases, relações $\mathrm{Ca}: \mathrm{Mg}$ e doses de $\mathrm{P}$, ao nível de $5 \%$ (Quadro 6). 
As saturações por bases diferenciam-se entre si quanto ao $\mathrm{N}$ absorvido (Quadro 7). Constataram-se reduções nos valores de $\mathrm{N}$ absorvido pelas plantas com aumento da saturação por bases. Esses resultados concordam com os obtidos por CARMELLO (1989) para a cultura do milho.

$\mathrm{O}$ acúmulo de $\mathrm{N}$ na parte aérea sofreu influência significativa das relações Ca:Mg, (Quadro 8). Constata-se uma tendência de aumento na absorção de $\mathbf{N}$, com acréscimos na proporção de Ca no solo. A menor quantidade de $\mathrm{N}$ total absorvido pelas

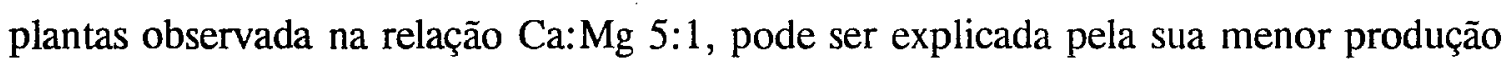
de matéria seca (Figura 8). Entretanto, em gramíneas forrageiras, MARUN (1990) observou que os valores de $\mathrm{N}$ absorvidos decresceram, à medida que se elevou as relações Ca:Mg no solo. Por outra parte, CARMELLO (1989), não constatou influência da relação Ca: $\mathrm{Mg}$ na extração de $\mathrm{N}$. Os valores de $\mathrm{N}$ extraído e acumulado na parte aérea das plantas correlacionaram-se com os de $\mathrm{Ca}\left(\mathrm{r}=0,8996^{* *}\right)$.

Quanto aos valores de $\mathrm{N}$ absorvido, ocorreram aumentos na acumulação de $\mathrm{N}$ para parte aérea, quando as doses de P foram aumentadas (Quadro 9). A dose de 200 ppm de $\mathrm{P}$ apresentou maior absorção de $\mathrm{N}$ e não se diferenciou da dose de $100 \mathrm{ppm}$ de P (Figura 9). As quantidades acumuladas de $\mathrm{N}$ na parte aérea, correlacionaram-se com o P extraído $\left(\mathrm{r}=0,8213^{* *}\right)$.

\subsubsection{Teores na parte aérea das plantas e $\mathbf{P}$ absorvido}

Através da análise de variância dos dados de teor de $\mathrm{P}$ na planta, observa-se efeito significativo ao nível de 1\%, para todas as causas de variação (Quadro 14). 


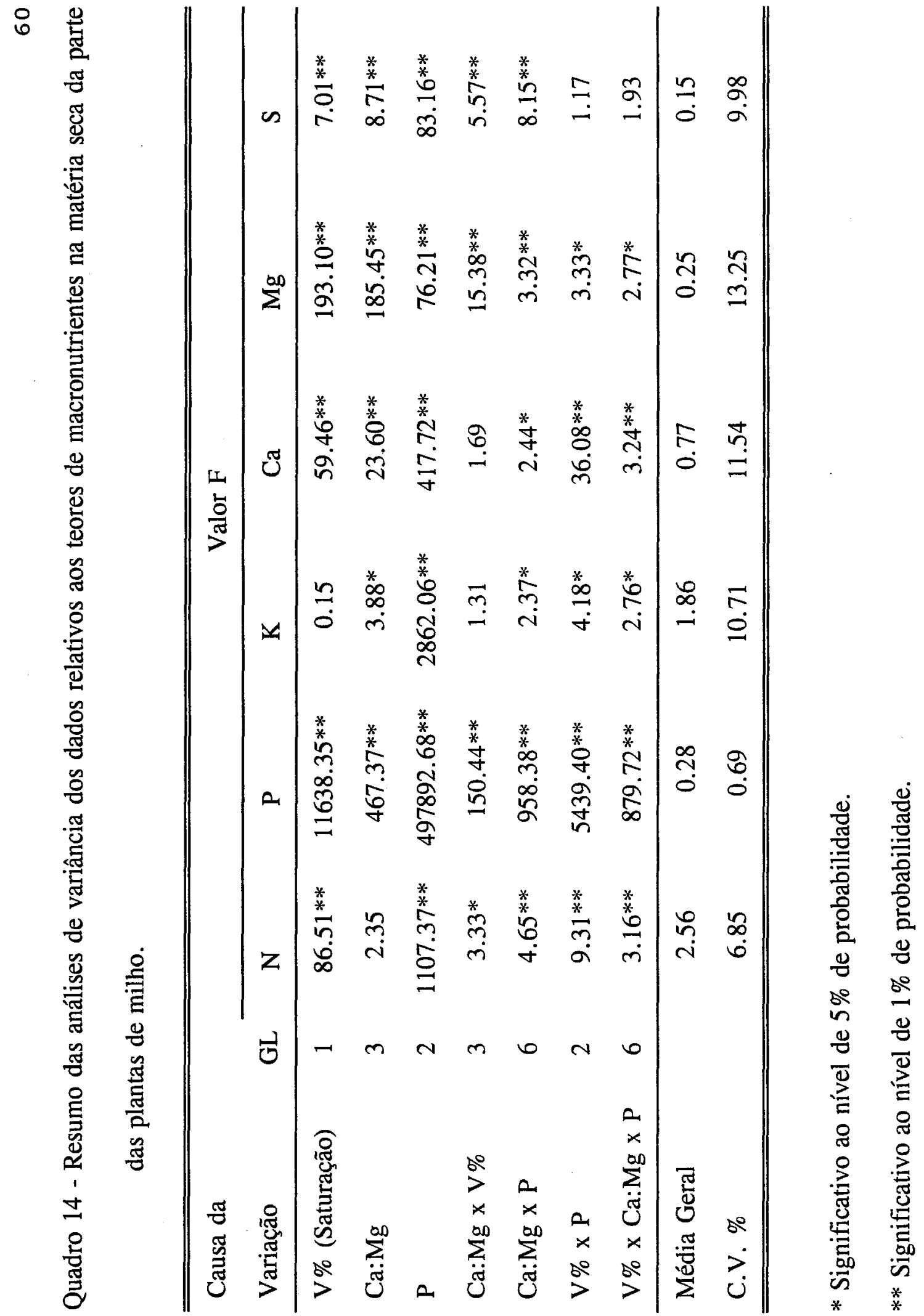


As saturações por bases influiram significativamente o teor de $\mathrm{P}$ nos tecidos (Quadro 15). A concentração de P na parte aérea, para a saturação por bases de $70 \%$ foi superior àquela verificada para a saturação por bases de $50 \%$, o que pode ser atribuído ao aumento na disponibilidade de $\mathrm{P}$ no solo, pela adição do corretivo.

A concentração de $\mathrm{P}$ na parte aérea, sob influência das relações $\mathrm{Ca}: \mathrm{Mg}$ mostrou que a relação $\mathrm{Ca}: \mathrm{Mg}$ de $3: 1$ proporcionou o maior teor de $\mathrm{P}$ nas plantas, apresentando-se significativamente diferente às demais relações $\mathrm{Ca}: \mathrm{Mg}$ estudadas (Quadro 16). Relações Ca:Mg mais amplas provocaram redução na concentração de $\mathrm{P}$ na parte aérea do milho, possivelmente em razão da adição de doses mais elevadas de carbonato de cálcio no solo, que vai fornecendo cada vez mais $\mathrm{Ca}$, dimuindo os teores de $\mathrm{Mg}$ no solo. A absorção do $\mathrm{P}$ é fortemente influenciada pela concentração de $\mathrm{Mg}$ no meio, por efeito sinergístico (MALAVOLTA, 1980). Através da análise de correlação verifica-se a associação negativa entre o teor de $\mathrm{P}$ nos tecidos e de $\mathrm{Ca}(\mathrm{r}=-0,6341)$.

Quanto aos valores dos teores observados em função das doses de fósforo aplicado (Quadro 17), constata-se elevação no teor de $\mathrm{P}$ com acréscimos da dose de $\mathrm{P}$ aplicada. A dose de $200 \mathrm{ppm}$ de $\mathrm{P}$ mostrou-se mais eficiente ao proporcionar maior concentração de $\mathrm{P}$ na parte aérea das plantas, refletindo a condição prevalescente no solo. Pesquisas conduzidas por SHERCHAND \& WHITNEY (1985); SIMARD et al. (1988); PECK \& MacDONALD (1989), têm constatado acréscimos no teor de P na planta com os níveis do nutriente aplicado. Ao associar os teores de $\mathrm{P}$ na parte aérea com o peso seco, observaram-se correlações positivas $\left(r=0,7091^{* *}\right)$. 
Quando as relações Ca:Mg foram avaliadas para cada saturação por bases, os teores de $\mathrm{P}$ nos tecidos acompanharam a mesma tendência observada para a concentração de P na parte aérea sob influência das relações Ca:Mg (Quadro 22). Verificou-se maior teor de P na relação Ca: $\mathrm{Mg} 3: 1$, sendo que a saturação por bases de $70 \%$ mostrou maior teor de $\mathrm{P}$ na parte aérea do milho.

Quadro 22 - Teores de P na matéria seca da parte aérea das plantas de milho (\%), em função das relações $\mathrm{Ca}: \mathrm{Mg}$ no solo e saturações por bases.

\begin{tabular}{ccc}
\hline \hline Relação & \multicolumn{2}{c}{ Saturação por bases (\%) } \\
\cline { 2 - 3 } Ca:Mg & 50 & 70 \\
\hline $2: 1$ & $0.253 \mathrm{c}$ & $0.305 \mathrm{~b}$ \\
$3: 1$ & $0.272 \mathrm{a}$ & $0.310 \mathrm{a}$ \\
$4: 1$ & $0.246 \mathrm{~d}$ & $0.295 \mathrm{c}$ \\
$5: 1$ & $0.263 \mathrm{~b}$ & $0.294 \mathrm{c}$ \\
\hline
\end{tabular}

D.M.S. $5 \%=0.002$

Médias seguidas da mesma letra, nas colunas, não diferem estatisticamente entre si, pelo teste de Tukey, ao nível de $5 \%$ de probabilidade.

Equações de regressão em função das relações $\mathrm{Ca}: \mathrm{Mg}$ e das saturações por bases para as concentrações de P na matéria seca das plantas de milho.

$$
\begin{array}{ll}
\text { V50 : } y=1,596975 x-0,212723 x^{2} & R^{2}=0,90^{* *} \\
\text { V70 }: y=1,441472 x-0,197357 x^{2} & R^{2}=0,88^{* *}
\end{array}
$$


Ao avaliar o efeito das relações $\mathrm{Ca}: \mathrm{Mg}$ no solo e das doses de $\mathrm{P}$ aplicadas, constata-se que foi significativo em todos os casos (Quadro 23). A dose de $200 \mathrm{ppm}$ de $\mathrm{P}$ da relação Ca:Mg 3:1 mostrou-se mais eficiente e conferiu o maior teor de $\mathrm{P}$ nas plantas, com diferença estatística das outras relações Ca:Mg. As relações Ca:Mg 2:1 e 5:1 para a dose de $100 \mathrm{ppm}$ de $\mathrm{P}$, que não se diferenciaram entre si, foram superiores às relações $\mathrm{Ca}: \mathrm{Mg} 3: 1 \mathrm{e} \mathrm{4:1.}$

Quadro 23 - Teores de P na matéria seca da parte aérea nas plantas de milho (\%), em função das relações Ca: $\mathrm{Mg}$ no solo e doses de $\mathrm{P}$ aplicadas.

\begin{tabular}{cccc}
\hline Relação & \multicolumn{3}{c}{ Doses de $\mathrm{P}\left(\mu \mathrm{g} . \mathrm{cm}^{-3}\right)$} \\
\cline { 2 - 4 } Ca:Mg & 0 & 100 & 200 \\
\hline $2: 1$ & $0.052 \mathrm{~b}$ & $0.265 \mathrm{a}$ & $0.519 \mathrm{c}$ \\
$3: 1$ & $0.057 \mathrm{a}$ & $0.246 \mathrm{~b}$ & $0.570 \mathrm{a}$ \\
$4: 1$ & $0.053 \mathrm{~b}$ & $0.219 \mathrm{c}$ & $0.539 \mathrm{~b}$ \\
$5: 1$ & & & $0.514 \mathrm{~d}$ \\
\hline D.M.S. $5 \%=0.002$ & $0.058 \mathrm{a}$ & $0.264 \mathrm{a}$ & \\
\hline \hline
\end{tabular}

Médias seguidas da mesma letra, nas colunas, não diferem estatisticamente entre si, pelo teste de Tukey, ao nível de $5 \%$ de probabilidade. 
Equações de regressão para o teor de P na parte aérea em função das relações $\mathrm{Ca}: \mathrm{Mg}$ em interação com as doses de $\mathrm{P}$ aplicadas no solo.

$$
\begin{array}{ll}
\text { P0 : } y=2,317566 x-0,325523 x^{2} & R^{2}=0,99^{* *} \\
\text { P100: } y=1,069424 x-0,143581 x^{2} & R^{2}=0,99^{* *} \\
\text { P200: } y=1,170680 x-0,146016 x^{2} & R^{2}=0,97^{* *}
\end{array}
$$

$\mathrm{O}$ teor de $\mathrm{P}$ na planta sob influência das saturações por bases e doses de $\mathrm{P}$ mostrou que o efeito foi significativo em todos os casos (Quadro 24). A dose de 200 $\mathrm{ppm}$ de $\mathrm{P}$ proporcionou maior concentração de $\mathrm{P}$ na parte aérea das plantas, sendo que a saturação por bases de $70 \%$ for superior à saturação por bases de $50 \%$, ao conferir maior teor de $\mathrm{P}$ no tecido das plantas de milho.

Quadro 24 - Teores de P na matéria seca da parte aérea das plantas de milho (\%), em função das saturações de bases e doses de $\mathrm{P}$ aplicadas.

\begin{tabular}{cccc}
\hline \hline Saturação por bases & \multicolumn{3}{c}{ Doses de P $\left(\mu \mathrm{g} . \mathrm{cm}^{-3}\right)$} \\
\cline { 2 - 4 }$\%$ & 0 & 100 & 200 \\
\hline 50 & $0.056 \mathrm{a}$ & $0.232 \mathrm{~b}$ & $0.487 \mathrm{~b}$ \\
70 & $0.054 \mathrm{~b}$ & $0.265 \mathrm{a}$ & $0.584 \mathrm{a}$ \\
\hline D.M.S. $5 \%=0.001$ & & \\
\hline
\end{tabular}

Médias seguidas da mesma letra, nas colunas, não diferem estatisticamente entre si, pelo teste de Tukey, ao nível de $5 \%$ de probabilidade. 
Pelo desdobramento da interação saturação por bases x relação Ca: $\mathrm{Mg}$ x P, observa-se que a influência foi significativa em todos os casos (Quadro 25). Verifica-se maiores teores de $\mathrm{P}$ na parte aérea das plantas, na dose de $200 \mathrm{ppm}$ de $\mathrm{P}$ e na relação Ca:Mg 3:1, independente da saturação por bases, sendo a saturação por bases de $70 \%$ aquela que proporcionou o maior teor no tecido das plantas.

Quadro 25 - Teores de P na matéria seca da parte aérea das plantas de milho (\%), em função dos tratamentos.

\begin{tabular}{ccccc}
\hline \hline Saturação por bases & Relação & \multicolumn{3}{c}{ Doses de P $\left(\mu \mathrm{g} . \mathrm{cm}^{-3}\right)$} \\
\cline { 3 - 5 }$\%$ & $\mathrm{Ca}: \mathrm{Mg}$ & 0 & 100 & 200 \\
\hline 50 & $2: 1$ & $0.055 \mathrm{~b}$ & $0.263 \mathrm{a}$ & $0.440 \mathrm{~d}$ \\
& $3: 1$ & $0.060 \mathrm{a}$ & $0.234 \mathrm{~b}$ & $0.522 \mathrm{a}$ \\
& $4: 1$ & $0.057 \mathrm{ab}$ & $0.196 \mathrm{c}$ & $0.485 \mathrm{c}$ \\
& $5: 1$ & $0.054 \mathrm{~b}$ & $0.234 \mathrm{~b}$ & $0.501 \mathrm{~b}$ \\
\hline 70 & $2: 1$ & $0.050 \mathrm{c}$ & $0.267 \mathrm{~b}$ & $0.598 \mathrm{~b}$ \\
& $3: 1$ & $0.054 \mathrm{~b}$ & $0.259 \mathrm{c}$ & $0.618 \mathrm{a}$ \\
& $4: 1$ & $0.050 \mathrm{c}$ & $0.242 \mathrm{~d}$ & $0.593 \mathrm{c}$ \\
& $5: 1$ & $0.061 \mathrm{a}$ & $0.294 \mathrm{a}$ & $0.527 \mathrm{~d}$ \\
\hline
\end{tabular}

D.M.S. $5 \%=0.003$

Médias seguidas da mesma letra, nas colunas, não diferem estatisticamente entre si, pelo teste de Tukey, ao nível de $5 \%$ de probabilidade. 
Os resultados da análise de variância dos valores de $\mathrm{P}$ absorvido, indicaram efeito significativo ao nível de $1 \%$ para todos os parâmetros estudados (Quadro 6).

Quando se analisou o efeito das saturações por bases, a saturaçāo por bases de $70 \%$ mostrou-se mais eficiente (Quadro 7), é notório o aumento no acúmulo de $\mathrm{P}$ na parte aérea quando a saturação por bases fọi incrementada.

Quanto à quantidade acumulada de $\mathrm{P}$ na parte aérea, em função das relações Ca: Mg no solo, houve uma tendência de diminuição com acréscimos na proporção de Ca no solo (Quadro 8). Nota-se que as relações Ca:Mg 3:1 e 2:1 proporcionaram maiores valores de absorção de $P$ que as relações $C a: M g ~ 5: 1$ e 4:1, as quais não diferiram entre si.

Os valores de $\mathrm{P}$ absorvido em função das doses de $\mathrm{P}$ aplicadas, variaram de forma significativa, quando os níveis de $\mathrm{P}$ foram aumentados (Quadro 9). A dose de 200 ppm de $\mathrm{P}$ foi superior, em termos de quantidade de $\mathrm{P}$ acumulada na parte aérea do milho, às doses de 0 e $100 \mathrm{ppm}$ de $\mathrm{P} . \mathrm{O}$ mesmo comportamento foi verificado quando os teores de $\mathbf{P}$ na parte aérea das plantas foram avaliados para cada uma das doses de $\mathrm{P}$ aplicadas no solo. Isso mostra que esses resultados devem-se às diferenças de fertilidade existentes entre os níveis da adubação fosfatada adicionados.

A quantidade de $\mathrm{P}$ na parte aérea das plantas, avaliada para as relações $\mathrm{Ca}: \mathrm{Mg}$ e as saturações por bases, mostrou maior acúmulo de P na saturação por bases de $70 \%$ (Quadro 26). As relações Ca:Mg 3:1 e 2:1 mostraram-se as mais eficientes. 
Quadro 26 - Quantidade acumulada de P na parte aérea das plantas de milho (mg vaso $\left.^{-1}\right)$, em função das relações $\mathrm{Ca}: \mathrm{Mg}$ no solo e saturações por bases.

\begin{tabular}{ccc}
\hline Relação & \multicolumn{2}{c}{ Saturação por bases $(\%)$} \\
\cline { 2 - 3 } Ca:Mg & 50 & 70 \\
\hline $2: 1$ & $64,69 \mathrm{a}$ & $82.47 \mathrm{a}$ \\
$3: 1$ & $67.90 \mathrm{a}$ & $84.44 \mathrm{a}$ \\
$4: 1$ & $52.05 \mathrm{~b}$ & $80.03 \mathrm{ab}$ \\
$5: 1$ & $53.79 \mathrm{~b}$ & $75.14 \mathrm{~b}$ \\
\hline
\end{tabular}

D.M.S. $5 \%=5.69$

Médias seguidas da mesma letra, nas colunas, não diferem estatisticamente entre si, pelo teste de Tukey, ao nível de $5 \%$ de probabilidade.

Equações de regressão para a quantidade acumulada de $\mathrm{P}$ na parte aérea do milho em função das relações Ca:Mg em interação com as saturações por bases.

$$
\begin{array}{ll}
\text { V50 : } y=41,855126 x-6,464936 x^{2} & R^{2}=0,62 * * \\
V 70: y=52,290547 x-7,631937 x^{2} & R^{2}=0,60 * *
\end{array}
$$

Ao avaliar a quantidade de $\mathrm{P}$ absorvido pelas plantas, sob influência das relações Ca: $\mathrm{Mg}$ e doses de $\mathrm{P}$ aplicadas, verificou-se efeito significativo das doses de 100 e 200 ppm de P (Quadro 27). A dose de 200 ppm no relação Ca:Mg 3:1 mostrou-se a mais eficiente ao proporcionar mais acúmulo de $\mathrm{P}$. 
Quadro 27 - Quantidade acumulada de P na parte aérea das plantas de milho (mg vaso $^{-1}$ ), em função das relaçōes Ca: $\mathrm{Mg}$ no solo e doses de $\mathrm{P}$ aplicadas.

\begin{tabular}{cccc}
\hline \hline Relação & \multicolumn{3}{c}{ Doses de P $\left(\mu \mathrm{g} . \mathrm{cm}^{-3}\right)$} \\
\cline { 2 - 4 } Ca:Mg & 0 & 100 & 200 \\
\hline $2: 1$ & $1.67 \mathrm{a}$ & $79.11 \mathrm{a}$ & $139.96 \mathrm{~b}$ \\
$3: 1$ & $1.93 \mathrm{a}$ & $73.11 \mathrm{ab}$ & $153.47 \mathrm{a}$ \\
$4: 1$ & $1.77 \mathrm{a}$ & $63.63 \mathrm{c}$ & $132.71 \mathrm{c}$ \\
$5: 1$ & $1.94 \mathrm{a}$ & $72.06 \mathrm{~b}$ & $119.39 \mathrm{~d}$ \\
\hline
\end{tabular}

D.M.S. $5 \%=6.97$

Médias seguidas da mesma letra, nas colunas, não diferem estatisticamente entre si, pelo teste de Tukey, ao nível de 5\% de probabilidade.

Equações de regressão para os valores acumulados de $\mathrm{P}$ sob influência das relações Ca: $\mathrm{Mg}$ e das doses de $\mathrm{P}$.

$$
\begin{aligned}
& \text { P0 : } y=1,044823 x-0,135923 x^{2} \quad R^{2}=0,98^{* *} \\
& \text { P100: } y=46,087851 x-6,668076 x^{2} \quad R^{2}=0,97^{* *} \\
& \text { P200: } y=94,085836 x-14,341310 x^{2} R^{2}=0,97^{* *}
\end{aligned}
$$


Avaliando o efeito das saturaçōes por bases e das doses de $\mathrm{P}$, nota-se que a influência foi significativa para as doses de 100 e $200 \mathrm{ppm}$ de P (Quadro 28). As quantidades de $\mathrm{P}$ absorvidas foram superiores na dose de $200 \mathrm{ppm}$ de $\mathrm{P}$. O aumento da saturação por bases promoveu um acréscimo no acúmulo de $\mathrm{P}$ na parte aérea.

Quadro 28 - Quantidade acumulada de P na parte aérea das plantas de milho (mg vaso $^{-1}$ ), em função das saturações por bases e doses de $\mathrm{P}$ aplicadas.

\begin{tabular}{cccc}
\hline \hline Saturação por bases & \multicolumn{3}{c}{ Doses de P $\left(\mu \mathrm{g} . \mathrm{cm}^{-3}\right)$} \\
\cline { 2 - 4 }$\%$ & 0 & 100 & 200 \\
\hline 50 & $1.95 \mathrm{a}$ & $64.87 \mathrm{~b}$ & $111.99 \mathrm{~b}$ \\
70 & $1.70 \mathrm{a}$ & $79.09 \mathrm{a}$ & $160.77 \mathrm{a}$ \\
\hline
\end{tabular}

D.M.S. $5 \%=3.73$

Médias seguidas da mesma letra, nas colunas, não diferem estatisticamente entre si, pelo teste de Tukey, ao nível de $5 \%$ de probabilidade.

No desdobramento da interação saturação por bases x relação Ca:Mg x P, verifica-se efeito significativo das doses de 100 e 200 ppm de P nas duas saturações por bases (Quadro 29). Os valores acumulados de $\mathrm{P}$ mostraram a mesma tendência observada para os teores na parte aérea. 
As plantas de milho apresentaram um aumento nos valores de $\mathrm{P}$ absorvido, à medida que se elevaram as doses de $\mathrm{P}$ no solo. A relação $\mathrm{Ca}: \mathrm{Mg} 3: 1$ proporcionou maiores quantidades acumuladas de $\mathrm{P}$ na parte aérea das plantas de milho na dose de 200 ppm de P, independentemente da saturação por bases, sendo a saturação por bases de $70 \%$ aquela que mostrou a maior quantidade de $\mathrm{P}$ absorvido.

Quadro 29 - Quantidade acumulada de P na parte aérea das plantas de milho (mg vaso $\left.^{-1}\right)$, em função dos tratamentos.

\begin{tabular}{ccccc}
\hline Saturação por bases & Relação & \multicolumn{3}{c}{ Doses de $\mathrm{P}\left(\mu \mathrm{g} . \mathrm{cm}^{-3}\right)$} \\
\cline { 3 - 5 }$\%$ & Ca:Mg & 0 & 100 & 200 \\
\hline 50 & $2: 1$ & $1.97 \mathrm{a}$ & $76.92 \mathrm{a}$ & $115.17 \mathrm{~b}$ \\
& $3: 1$ & $2.04 \mathrm{a}$ & $67.88 \mathrm{ab}$ & $134.78 \mathrm{a}$ \\
& $4: 1$ & $1.94 \mathrm{a}$ & $56.10 \mathrm{bc}$ & $98.10 \mathrm{c}$ \\
& $5: 1$ & $1.87 \mathrm{a}$ & $59.57 \mathrm{~b}$ & $99.92 \mathrm{c}$ \\
\hline 70 & $2: 1$ & $1.37 \mathrm{a}$ & $81.29 \mathrm{a}$ & $164.74 \mathrm{a}$ \\
& $3: 1$ & $1.82 \mathrm{a}$ & $79.33 \mathrm{ab}$ & $172.16 \mathrm{a}$ \\
& $4: 1$ & $1.60 \mathrm{a}$ & $71.16 \mathrm{~b}$ & $167.32 \mathrm{a}$ \\
& $5: 1$ & $2.01 \mathrm{a}$ & $84.56 \mathrm{a}$ & $138.85 \mathrm{~b}$ \\
\hline
\end{tabular}

D.M.S. $5 \%=9.86$

Médias seguidas da mesma letra, nas colunas, não diferem estatisticamente entre si, pelo teste de Tukey, ao nível de $5 \%$ de probabilidade. 


\subsubsection{Teores na parte aérea das plantas e $\mathrm{K}$ absorvido}

As análises de variância dos dados dos teores nos tecidos das plantas mostraram efeito significativo ao nível de $5 \%$ para relações $\mathrm{Ca}: \mathrm{Mg}$, doses de $\mathrm{P}$ e as interações saturação por bases x P, relação Ca: $\mathrm{Mg}$ x $\mathrm{P}$ e saturação por bases x relação Ca:Mg x P (Quadro 14).

As concentrações de $\mathrm{K}$ na parte aérea das plantas, foram influenciadas pelas relações Ca:Mg no solo (Quadro 16). Constata-se tendência de aumento na relação Ca:Mg 5:1. Estes resultados podem ser atribuídos a um sinergismo do $\mathrm{Ca}$ e do $\mathrm{K}$, quando encontrados em proporções adequadas no meio de crescimento e a um maior antagonismo do $\mathrm{K}$ com o $\mathrm{Mg}$. Em estudo realizado em plantas de arroz e milho, SILVA \& RITCHEY (1982) notaram uma queda na absorção de Mg pelas plantas, efeito este que dependia da concentração de $\mathrm{K}$ no meio de crescimento, sendo a redução no acúmulo de $\mathrm{Mg}$ na matéria seca das plantas pelo $\mathrm{K}$ mais intensa que aquela do $\mathrm{K}$ pelo $\mathrm{Mg}$.

$\mathrm{O}$ efeito depressivo do $\mathrm{K}$ se deve provavelmente à maior facilidade do íon $\mathrm{K}$, de entrar nas células da raíz. Todos os cátions do meio são atraídos pelo potencial eletronegativo das células. Entretanto, os íons que penetram a membrana plasmática mais facilmente podem saturar o potencial eletronegativo da célula, deprimindo a absorção de outros íons (MENGEL \& KIRBY, 1987). Para iguais concentrações externas, a capacidade competitiva dos cátions obedece à seguinte ordem decrescente: $\mathrm{K}>\mathrm{Na}>\mathrm{Mg}>\mathrm{Ca}$ (MALAVOLTA et al., 1989). 
Outra explicação é que provavelmente ocorreu consumo de luxo de K. Às vezes, as plantas acumulam mais $\mathrm{K}$ do que necessitam para suas funções, não tendo contribuição alguma no crescimento ou na produção, o que parece provável, admitindo a maior absorção de $\mathrm{K}$ onde houve menor produção de matéria seca.

MARUN (1990) observou uma tendência de elevação no teor de K com acréscimo na relação Ca: $\mathrm{Mg}$ no solo. Entretanto, os resultados dos trabalhos de SOARES (1975); JUO \& UZO (1970) e CARMELLO (1989) não concordam com este resultado. SIMARD et al. (1988) verificaram decréscimos no teor de K pela aplicação de $\mathrm{CaCO}_{3}$. Através da análise de correlação observou-se associação positiva do $\mathrm{K}$ com os teores de Ca na parte aérea $\left(\mathrm{r}=0,8695^{* *}\right)$.

Houve efeito significativo das doses de $\mathrm{P}$ aplicadas nos valores de $\mathrm{K}$ nas plantas (Quadro 17). Verifica-se uma tendência de redução no teor de K com o aumento dos níveis de $\mathrm{P}$. A concentração de $\mathrm{K}$ na parte aérea das plantas mostrou-se menor na dose de 100 ppm de $\mathrm{P}$ do que na dose de 200 ppm, mas não diferiram entre si. Os teores de $\mathrm{K}$ foram maiores, onde houve menor produção de matéria seca. Assim, podese atribuir a este comportamento, um efeito de diluição do $\mathrm{K}$ na parte aérea das plantas de milho. SIMARD et al. (1988) e PECK \& MacDONALD (1989) observaram decréscimos na concentração de $\mathrm{K}$ pela aplicação de $\mathrm{P}$ ao solo. $\mathrm{O} \mathrm{K}$ na parte aérea correlacionou negativamente com o peso seco da parte aérea das plantas de milho $(\mathrm{r}=$ $\left.0,9721^{* *}\right)$ e com o $\mathrm{P}$ no tecido das plantas $\left(\mathrm{r}=-0.7666^{* *}\right)$. Houve estreita correlação de $\mathrm{K}$ no tecido das plantas com a concentração de $\mathrm{N}$ na parte aérea do milho ( $\mathrm{r}=$ $\left.0,9387^{* *}\right)$. 
Quando as relações Ca: $\mathrm{Mg}$ foram analisadas para as respectivas doses de $\mathrm{P}$ aplicadas, observou-se uma tendência de redução nos valores de K nos tecidos, com a elevação das relações $\mathrm{Ca}: \mathrm{Mg}$ (Quadro 30). Verificou-se que a influência foi significativa, apenas na dose de $0 \mathrm{ppm}$ de $\mathrm{P}$. As relações Ca:Mg 2:1 e 5:1 proporcionaram maiores teores de $\mathrm{K}$ nas plantas que as relações Ca:Mg 3:1 e 4:1, as quais não diferiram entre si.

Quadro 30 - Teores de K na matéria seca da parte aérea das plantas de milho (\%), em função das relações Ca:Mg no solo e doses de $\mathrm{P}$ aplicadas.

\begin{tabular}{cccc}
\hline \hline Relação & \multicolumn{3}{c}{ Doses de P $\left(\mu \mathrm{g} . \mathrm{cm}^{-3}\right)$} \\
\cline { 2 - 4 } Ca:Mg & 0 & 100 & 200 \\
\hline $2: 1$ & $4.26 \mathrm{a}$ & $0.72 \mathrm{a}$ & $0.75 \mathrm{a}$ \\
$3: 1$ & $3.98 \mathrm{~b}$ & $0.72 \mathrm{a}$ & $0.79 \mathrm{a}$ \\
$4: 1$ & $3.86 \mathrm{~b}$ & $0.61 \mathrm{a}$ & $0.81 \mathrm{a}$ \\
$5: 1$ & $4.05 \mathrm{ab}$ & $0.80 \mathrm{a}$ & $0.96 \mathrm{a}$ \\
\hline
\end{tabular}

D.M.S. $5 \%=0.26$

Médias seguidas da mesma letra, nas colunas, não diferem estatisticamente entre si, pelo teste de Tukey, ao nível de 5\% de probabilidade. 
Equações de regressão para os teores de $\mathrm{K}$ na planta, em função da interação relação Ca: $\mathrm{Mg}$ x doses de $\mathrm{P}$ aplicadas no solo.

$$
\begin{array}{ll}
\text { P0 : y }=2,493920 x-0,350245 x^{2} & R^{2}=0,98^{* *} \\
\text { P100:y }=0,399788 x-0,051357 x^{2} & R^{2}=0,97^{* *} \\
\text { P200:y }=0,420860 x-0,479630 x^{2} & R^{2}=0,98^{* *}
\end{array}
$$

Avaliando o efeito das saturações por bases e das doses de $\mathrm{P}$, observa-se uma redução nos teores de $\mathrm{K}$ na parte aérea com acréscimos dos níveis de $\mathbf{P}$ (Quadro 31). Apenas na dose de $0 \mathrm{ppm}$ de $\mathrm{P}$, as saturações por bases apresentaram efeito significativo ao nível de $5 \%$ na concentração de $\mathrm{K}$ na parte aérea das plantas. Os teores de $\mathrm{K}$ para a saturação de $70 \%$ foram superiores àqueles encontrados para a saturação por bases de $50 \%$.

Quadro 31 - Teores de K na matéria seca da parte aérea das plantas de milho (\%), em função das saturações de bases e doses de P aplicadas.

\begin{tabular}{cccc}
\hline \hline Saturação por bases & \multicolumn{3}{c}{ Doses de P $\left(\mu \mathrm{g} \cdot \mathrm{cm}^{-3}\right)$} \\
\cline { 2 - 4 }$\%$ & 0 & 100 & 200 \\
\hline 50 & $3.96 \mathrm{~b}$ & $0.75 \mathrm{a}$ & $0.89 \mathrm{a}$ \\
70 & $4.11 \mathrm{a}$ & $0.67 \mathrm{a}$ & $0.77 \mathrm{a}$ \\
\hline
\end{tabular}

D.M.S. $5 \%=0.14$

Médias seguidas da mesma letra, nas colunas, não diferem estatisticamente entre si, pelo teste de Tukey, ao nível de $5 \%$ de probabilidade. 
Pelo desdobramento da interação saturação por bases x relação Ca:Mg x P, nota-se influência significativa para a dose $0 \mathrm{ppm}$ de $\mathrm{P}$, que conferiu os maiores teores nos tecidos (Quadro 32). As relações Ca:Mg 2:1 e 3:1 da saturação por bases de 50\% mostraram maiores concentrações de $K$ na parte aérea das plantas que as relações Ca:Mg 4:1 e 5:1. Entretanto, na saturação por bases de $70 \%$, as relações Ca:Mg 5:1 e 2:1 proporcionaram os maiores teores de $\mathrm{K}$.

Quadro 32 - Teores de K na matéria seca da parte aérea das plantas de milho (\%), em função dos tratamentos.

\begin{tabular}{ccccc}
\hline \hline \multirow{2}{*}{$\begin{array}{c}\text { Saturação por bases } \\
\%\end{array}$} & Relação & \multicolumn{3}{c}{ Doses de P $\left(\mu \mathrm{g} . \mathrm{cm}^{-3}\right)$} \\
\cline { 3 - 5 } & Ca:Mg & 0 & 100 & 200 \\
\hline 50 & $2: 1$ & $4.28 \mathrm{a}$ & $0.72 \mathrm{a}$ & $0.79 \mathrm{a}$ \\
& $3: 1$ & $4.04 \mathrm{ab}$ & $0.75 \mathrm{a}$ & $0.81 \mathrm{a}$ \\
& $4: 1$ & $3.82 \mathrm{~b}$ & $0.68 \mathrm{a}$ & $0.88 \mathrm{a}$ \\
& $5: 1$ & $3.71 \mathrm{~b}$ & $0.84 \mathrm{a}$ & $1.07 \mathrm{a}$ \\
\hline 70 & $2: 1$ & $4.24 \mathrm{ab}$ & $0.71 \mathrm{a}$ & $0.71 \mathrm{a}$ \\
& $3: 1$ & $3.93 \mathrm{~b}$ & $0.68 \mathrm{a}$ & $0.78 \mathrm{a}$ \\
& $4: 1$ & $3.90 \mathrm{~b}$ & $0.54 \mathrm{a}$ & $0.73 \mathrm{a}$ \\
& $5: 1$ & $4.38 \mathrm{a}$ & $0.76 \mathrm{a}$ & $0.85 \mathrm{a}$ \\
\hline
\end{tabular}

D.M.S. $5 \%=0.37$

Médias seguidas da mesma letra, nas colunas, não diferem estatisticamente entre si, pelo teste de Tukey, ao nível de $5 \%$ de probabilidade. 
A dose de $100 \mathrm{ppm}$ de $\mathrm{P}$ nas duas saturações por bases mostrou menores teores de $\mathrm{K}$ nos tecidos, sendo a relação $\mathrm{Ca}: \mathrm{Mg}$ 4:1 aquela que forneceu a menor concentração de $\mathrm{K}$ na parte aérea das plantas, embora as diferenças entre as relações Ca:Mg não tenham sido estatisticamente significativas.

Pela análise de variância nota-se que as relações Ca: $\mathrm{Mg}$ e as doses de $\mathrm{P}$ influenciaram significativamente ao nível de $1 \%$ na acumulação de $\mathrm{K}$ na parte aérea das plantas (Quadro 6).

As relações Ca:Mg 5:1 e 3:1, que não se diferenciaram entre si, mostraram-se superiores ao conferirem maior quantidade de $\mathrm{K}$ absorvido pelas plantas (Quadro 8). Verificou-se correlação entre a acumulação de $\mathrm{K}$ na parte aérea com a de Ca ( $\mathrm{r}=$ $\left.0,8419^{* *}\right)$.

Com relação ao acúmulo de $\mathrm{K}$ na parte aérea, em função das doses de $\mathrm{P}$ aplicadas, observa-se acréscimos nos valores de absorção de $\mathrm{K}$ com aumento dos níveis de $\mathrm{P}$ (Quadro 9). O conteúdo de $\mathrm{K}$ na matéria seca da parte aérea das plantas nas doses de 100 a 200 ppm de $P$ não diferiram entre si, mas apresentaram resultado superior ao conteúdo de $\mathrm{K}$ das plantas na dose de $0 \mathrm{ppm}$. O acúmulo de $\mathrm{K}$ na parte aérea do milho associou positivamente com os de $\mathrm{P}\left(\mathrm{r}=0,7363^{* *}\right)$ e de $\mathrm{N}\left(\mathrm{r}=0,8420^{* *}\right)$.

\subsubsection{Teores na parte aérea das plantas e Ca absorvido}

A análise de variância revelou efeito significativo ao nível de $5 \%$ das saturações por bases, relações $\mathrm{Ca}: \mathrm{Mg}$, doses de $\mathrm{P}$ e as interações saturação por bases 
x $P$, relação Ca: $M g$ x $P$, saturação por bases x relação Ca: $M g$ x $P$ para teores na parte aérea das plantas (Quadro 14).

As concentrações de Ca na parte aérea, foram influenciadas pelas saturações por bases (Quadro 15). Verifica-se um aumento significativo nos teores de Ca nos tecidos, com o aumento no valor da saturação por bases, evidenciando que os teores de Ca na planta estão relacionados com os níveis desse cátion aplicados nos corretivos.

Os teores de Ca na parte aérea das plantas, foram influenciadas pelas relações Ca:Mg no solo (Quadro 16). Constata-se um aumento no teor de $\mathrm{Ca}$, à medida que se elevou o valor da relação $\mathrm{Ca}: \mathrm{Mg}$ no solo pelos corretivos.

Nota-se que a relação Ca:Mg 5:1 foi estatisticamente superior. Com a elevação das relações Ca:Mg no solo, os corretivos colocam à disposição das plantas maiores quantidades de $\mathrm{Ca}$, que reflete nos maiores valores do nutriente encontrados na parte aérea das plantas do milho. Os resultados do presente trabalho são concordantes com os de ARANTES (1983); SMITH (1984); GROVE \& SUMMER (1985); CHAVES SOLERA (1988); CARMELLO (1989); MARUN (1990); KURIHARA (1991).

Com relação aos teores de Ca no tecido em função das doses de $\mathrm{P}$ aplicadas, evidencia-se uma tendência de redução no teor com aumento nos níveis de P (Quadro 17). A dose de $100 \mathrm{ppm}$ de $\mathrm{P}$, que mostrou menor concentração de Ca na parte aérea do milho, não se diferenciou da dose de 200 ppm de P.

Avaliando-se os teores de Ca no tecido, em função das relações $\mathrm{Ca}: \mathrm{Mg}$ e doses de P (Quadro 33), observa-se uma tendência de redução no teor de Ca com acréscimos dos níveis de $\mathrm{P}$ aplicados. As doses de $\mathrm{P}$ testadas na relação Ca:Mg 5:1 mostraram-se 
mais eficientes. Onde houve menor produção de matéria seca, os teores de Ca nas plantas foram maiores, e através da análise de correlação, verifica-se uma associação negativa entre o teor de $\mathrm{Ca}$ e o peso seco da parte aérea das plantas $\left(\mathrm{r}=-0,8570^{* *}\right)$. Pode-se atribuir a este comportamento um efeito de diluição do Ca na parte aérea do milho.

Quadro 33 - Teores de Ca na matéria seca da parte aérea das plantas de milho (\%), em função das relações Ca:Mg no solo e doses de P aplicadas.

\begin{tabular}{cccc}
\hline \hline Relação & \multicolumn{3}{c}{ Doses de P $\left(\mu \mathrm{g} \cdot \mathrm{cm}^{-3}\right)$} \\
\cline { 2 - 4 } Ca:Mg & 0 & 100 & 200 \\
\hline $2: 1$ & $1.12 \mathrm{ab}$ & $0.46 \mathrm{~b}$ & $0.46 \mathrm{c}$ \\
$3: 1$ & $1.06 \mathrm{~b}$ & $0.54 \mathrm{~b}$ & $0.58 \mathrm{~b}$ \\
$4: 1$ & $1.16 \mathrm{ab}$ & $0.53 \mathrm{~b}$ & $0.63 \mathrm{ab}$ \\
$5: 1$ & $1.21 \mathrm{a}$ & $0.70 \mathrm{a}$ & $0.74 \mathrm{a}$ \\
\hline
\end{tabular}

D.M.S. $5 \%=0.11$

Médias seguidas da mesma letra, nas colunas, não diferem estatisticamente entre si, pelo teste de Tukey, ao nível de $5 \%$ de probabilidade.

Equações de regressão para as concentrações do Ca em função das relações $\mathrm{Ca}: \mathrm{Mg}$ e das doses de $\mathrm{P}$. 


$$
\begin{array}{ll}
\text { P0 : y }=0,637948 x-0,081571 x^{2} & R^{2}=0,96 * * \\
\text { P100: y }=0,255672 x-0,024890 x^{2} & R^{2}=0,99 * * \\
\text { P200 : y }=0,267146 x-0,024324 x^{2} & R^{2}=0,99 * *
\end{array}
$$

$\mathrm{O}$ teor de $\mathrm{Ca}$ nos tecidos em relação às saturações por bases e doses de $\mathrm{P}$ aplicadas, mostrou uma tendência de redução com a elevação dos níveis de $\mathrm{P}$ adicionados (Quadro 34). Nota-se que a influência foi significativa para a dose $0 \mathrm{ppm}$ de $\mathrm{P}$, que conferiu maior concentração de Ca na parte aérea das plantas. Os teores de Ca nos tecidos das plantas foram superiores na saturação por bases de $70 \%$.

Quadro 34 - Teores de Ca na matéria seca da parte aérea das plantas de milho (\%), em função das saturações por bases e doses de P aplicadas.

\begin{tabular}{cccc}
\hline \hline Saturação por bases & \multicolumn{3}{c}{ Doses de P $\left(\mu \mathrm{g} . \mathrm{cm}^{-3}\right)$} \\
\cline { 2 - 4 }$\%$ & 0 & 100 & 200 \\
\hline 50 & $0.96 \mathrm{~b}$ & $0.54 \mathrm{a}$ & $0.59 \mathrm{a}$ \\
70 & $1.32 \mathrm{a}$ & $0.58 \mathrm{a}$ & $0.62 \mathrm{a}$ \\
\hline
\end{tabular}

D.M.S. $5 \%=0.06$

Médias seguidas da mesma letra, nas colunas, não diferem estatisticamente entre si, pelo teste de Tukey, ao nível de $5 \%$ de probabilidade. 
$\mathrm{O}$ desdobramento da interação saturação por bases $\mathrm{x}$ relação Ca:Mg x $\mathrm{P}$ mostrou que a influência não foi significativa para a dose 0 ppm da saturação por bases de 50\% (Quadro 35). Verificou-se maior teor de Ca na saturação por bases de $70 \%$ e na dose 0 ppm de P. A relação Ca:Mg 5:1, que não se diferenciou das relações Ca:Mg 4:1 e 2:1, proporcionou a maior concentração de Ca na parte aérea das plantas de milho.

Quadro 35 - Teores de Ca na matéria seca da parte aérea das plantas de milho (\%), em função dos tratamentos.

\begin{tabular}{ccccc}
\hline Saturação por bases & Relação & \multicolumn{3}{c}{ Doses de P $\left(\mu \mathrm{g} . \mathrm{cm}^{-3}\right)$} \\
\cline { 3 - 5 }$\%$ & Ca:Mg & 0 & 100 & 200 \\
\hline 50 & $2: 1$ & $0.92 \mathrm{a}$ & $0.43 \mathrm{~b}$ & $0.49 \mathrm{~b}$ \\
& $3: 1$ & $1.00 \mathrm{a}$ & $0.53 \mathrm{ab}$ & $0.54 \mathrm{~b}$ \\
& $4: 1$ & $0.94 \mathrm{a}$ & $0.52 \mathrm{ab}$ & $0.59 \mathrm{ab}$ \\
& $5: 1$ & $0.97 \mathrm{a}$ & $0.68 \mathrm{a}$ & $0.75 \mathrm{a}$ \\
\hline 70 & $2: 1$ & $1.32 \mathrm{a}$ & $0.50 \mathrm{~b}$ & $0.42 \mathrm{~b}$ \\
& $3: 1$ & $1.12 \mathrm{~b}$ & $0.55 \mathrm{ab}$ & $0.62 \mathrm{a}$ \\
& $4: 1$ & $1.38 \mathrm{a}$ & $0.55 \mathrm{ab}$ & $0.68 \mathrm{a}$ \\
& $5: 1$ & $1.45 \mathrm{a}$ & $0.71 \mathrm{a}$ & $0.74 \mathrm{a}$ \\
\hline
\end{tabular}

D.M.S. $5 \%=0.16$

Médias seguidas da mesma letra, nas colunas, não diferem estatisticamente entre si, pelo teste de Tukey, ao nível de $5 \%$ de probabilidade. 
A análise de variância mostrou que houve resposta ao Ca absorvido, com diferença estatística ao nível de 5\%, para todas as causas de variação (Quadro 6).

O efeito da saturação por bases no acúmulo de Ca na parte aérea mostrou que estes valores cresceram com a elevação da saturação por bases (Quadro 7).

A absorção de Ca foi influenciada significativamente pelas relações Ca:Mg no solo. Constatou-se uma tendência de aumento na acumulação de Ca na parte aérea, com o aumento no valor da relação Ca: $\mathrm{Mg}$ no corretivo (Quadro 8).

A relação Ca:Mg 5:1 mostrou-se mais eficiente e diferenciou-se das demais relações Ca:Mg. Os valores acumulados de $\mathrm{Ca}$ acompanharam a mesma tendência observada para os teores na parte aérea. A adição de corretivos com elevadas relações $\mathrm{Ca}: \mathrm{Mg}$ fornece mais $\mathrm{Ca}$ e vai aumentando os teores de $\mathrm{Ca}$ no solo, que em maior quantidade, compete com o Mg, ocorrendo maior absorção de Ca.

Houve efeito significativo das doses de $\mathrm{P}$ aplicadas nos valores de $\mathrm{Ca}$ absorvido. Evidencia-se que o aumento das doses de $\mathrm{P}$ aplicadas, tendeu a promover um aumento no acúmulo de $\mathrm{Ca}$ (Quadro 9). Observou-se uma maior absorção de Ca na dose de 100 ppm de $P$, a qual não se diferenciou da dose de 200 ppm de $P$.

Equações de regressão para os valores médios das quantidades acumuladas de Ca em função da interação relação Ca:Mg x saturação por bases.

$$
\begin{array}{ll}
\text { V50 : y }=57,517698 x-7,077654 x^{2} & R^{2}=0,80^{* *} \\
V 70: y=61,568782 x-6,511796 x^{2} & R^{2}=0,81^{* *}
\end{array}
$$


Avaliando o efeito das relações $\mathrm{Ca}: \mathrm{Mg}$ e das saturações por bases sobre a absorção de Ca, observou-se uma melhor resposta da saturação por bases de $70 \%$ em relação à saturação por bases de $50 \%$ (Quadro 36). A maior quantidade de Ca absorvido ocorreu na relação Ca:Mg 5:1.

Quadro 36 - Quantidade acumulada de Ca na parte aérea das plantas de milho (mg vaso $^{-1}$ ), em função das relações $\mathrm{Ca}: \mathrm{Mg}$ no solo e saturações por bases.

\begin{tabular}{ccc}
\hline Relação & \multicolumn{2}{c}{ Saturação por bases (\%) } \\
\cline { 2 - 3 } Ca:Mg & 50 & 70 \\
\hline $2: 1$ & $96.31 \mathrm{~b}$ & $102.02 \mathrm{c}$ \\
$3: 1$ & $108.74 \mathrm{ab}$ & $127.32 \mathrm{~b}$ \\
$4: 1$ & $100.78 \mathrm{~b}$ & $132.84 \mathrm{~b}$ \\
& & $149.73 \mathrm{a}$ \\
\hline
\end{tabular}

D.M.S. $5 \%=16.14$

Médias seguidas da mesma letra, nas colunas, não diferem estatisticamente entre si, pelo teste de Tukey, ao nível de 5\% de probabilidade. 
$\mathrm{O}$ efeito das relações Ca: $\mathrm{Mg}$ e das doses de $\mathrm{P}$, mostra uma tendência de aumento nos valores de $\mathrm{Ca}$ absorvido, com o aumento das doses de $\mathrm{P}$ aplicadas (Quadro 37). A influência não foi significativa para a dose de 0 ppm de P. A dose de 100 ppm de $\mathrm{P}$ da relação $\mathrm{Ca}: \mathrm{Mg}$ 5:1 promoveu a maior acumulação de Ca na parte aérea.

Quadro 37 - Quantidade acumulada de Ca na parte aérea das plantas de milho (mg vaso $^{-1}$ ), em função das relações $\mathrm{Ca}: \mathrm{Mg}$ no solo e doses de $\mathrm{P}$ aplicadas.

\begin{tabular}{cccc}
\hline \hline Relação & \multicolumn{3}{c}{ Doses de P $\left(\mu \mathrm{g} . \mathrm{cm}^{-3}\right)$} \\
\cline { 2 - 4 } Ca:Mg & 0 & 100 & 200 \\
\hline $2: 1$ & $34.41 \mathrm{a}$ & $139.48 \mathrm{c}$ & $123.61 \mathrm{~b}$ \\
$3: 1$ & $36.04 \mathrm{a}$ & $160.93 \mathrm{~b}$ & $157.12 \mathrm{a}$ \\
$4: 1$ & $37.89 \mathrm{a}$ & $156.62 \mathrm{bc}$ & $155.93 \mathrm{a}$ \\
$5: 1$ & $40.51 \mathrm{a}$ & $190.27 \mathrm{a}$ & $172.28 \mathrm{a}$ \\
\hline
\end{tabular}

D.M.S. $5 \%=19.77$

Médias seguidas da mesma letra, nas colunas, não diferem estatisticamente entre si, pelo teste de Tukey, ao nível de $5 \%$ de probabilidade.

Equações de regressão para valores de absorção de Ca em função das relações $\mathrm{Ca}: \mathrm{Mg}$ e as doses de $\mathrm{P}$ aplicadas no solo. 


$$
\begin{array}{ll}
\text { P0 : } y=20,195243 x-2,497533 x^{2} & R^{2}=0,98^{* *} \\
\text { P100: } y=81,005561 x-9,059278 x^{2} & R^{2}=0,99^{* *} \\
\text { P200: } y=77,428917 x-8,827464 x^{2} & R^{2}=0,97^{* *}
\end{array}
$$

Ao avaliar as saturações por bases para as doses de $\mathrm{P}$ aplicadas, observa-se que o aumento dos níveis de $\mathrm{P}$ testados tendeu a promover um aumento na acumulação de Ca na parte aérea (Quadro 38). Verifica-se que a influência não foi significativa para a dose de 0 ppm de $\mathrm{P}$. A dose de 100 ppm de $\mathrm{P}$ mostrou maior conteúdo de Ca na parte aérea das plantas de milho. A absorção de Ca para a saturação por bases de $70 \%$ foi superior àquela encontrada para a saturação por bases de $50 \%$.

Quadro 38 - Quantidade acumulada de Ca na parte aérea das plantas de milho (mg vaso $^{-1}$ ), em função das saturações por bases e doses de $\mathrm{P}$ aplicadas.

\begin{tabular}{cccc}
\hline Saturação por bases & \multicolumn{3}{c}{ Doses de P $\left(\mu \mathrm{g} . \mathrm{cm}^{-3}\right)$} \\
\cline { 2 - 4 }$\%$ & 0 & 100 & 200 \\
\hline 50 & $33.38 \mathrm{a}$ & $150.48 \mathrm{~b}$ & $134.75 \mathrm{~b}$ \\
70 & $41.04 \mathrm{a}$ & $173.17 \mathrm{a}$ & $169.72 \mathrm{a}$ \\
\hline
\end{tabular}

D.M.S. $5 \%=10.58$

Médias seguidas da mesma letra, nas colunas, não diferem estatisticamente entre si, pelo teste de Tukey, ao nível de 5\% de probabilidade. 
Pelo desdobramento da interação saturação por bases x relação Ca:Mg x P, observa-se que a influência foi significativa para as doses 100 e $200 \mathrm{ppm}$ das duas saturações por bases (Quadro 39). A relação Ca:Mg 5:1 independente destas, mostrou maiores quantidades acumuladas de Ca na parte aérea do milho.

Quadro 39 - Quantidade acumulada de Ca na parte aérea das plantas de milho (mg vaso $\left.^{-1}\right)$, em função dos tratamentos.

\begin{tabular}{ccccc}
\hline \hline Saturação por bases & Relação & \multicolumn{3}{c}{ Doses de P $\left(\mu \mathrm{g} \cdot \mathrm{cm}^{-3}\right)$} \\
\cline { 3 - 5 }$\%$ & Ca:Mg & 0 & 100 & 200 \\
\hline 50 & $2: 1$ & $33.03 \mathrm{a}$ & $126.72 \mathrm{~b}$ & $129.19 \mathrm{ab}$ \\
& $3: 1$ & $34.44 \mathrm{a}$ & $155.40 \mathrm{a}$ & $139.39 \mathrm{ab}$ \\
& $4: 1$ & $32.49 \mathrm{a}$ & $149.45 \mathrm{ab}$ & $120.41 \mathrm{~b}$ \\
& $5: 1$ & $33.55 \mathrm{a}$ & $173.35 \mathrm{a}$ & $150.02 \mathrm{a}$ \\
\hline 70 & $2: 1$ & $35.78 \mathrm{a}$ & $152.24 \mathrm{~b}$ & $118.04 \mathrm{a}$ \\
& $3: 1$ & $37.64 \mathrm{a}$ & $169.46 \mathrm{~b}$ & $174.86 \mathrm{~b}$ \\
& $4: 1$ & $43.29 \mathrm{a}$ & $163.78 \mathrm{~b}$ & $191.46 \mathrm{~b}$ \\
& $5: 1$ & $47.46 \mathrm{a}$ & $207.18 \mathrm{a}$ & $194.54 \mathrm{~b}$ \\
\hline
\end{tabular}

D.M.S. $5 \%=27.96$

Médias seguidas da mesma letra, nas colunas, não diferem estatisticamente entre si, pelo teste de Tukey, ao nível de $5 \%$ de probabilidade. 


\subsubsection{Teores na parte aérea das planta e Mg absorvido}

As análises de variância dos dados dos teores na parte aérea das plantas indicam efeito significativo ao nível de $5 \%$ para todas as causas de variação (Quadro 14).

Observa-se que a maior concentração de $\mathrm{Mg}$ na parte aérea ocorreu na saturação por bases de 70\% (Quadro 15).

Quanto aos valores dos teores no tecido, em função das relações $\mathrm{Ca}: \mathrm{Mg}$ no solo (Quadro 16), verifica-se que as plantas apresentaram uma redução nos seus teores nas plantas, com a elevação das relações $\mathrm{Ca}: \mathrm{Mg}$ no solo. A concentração de $\mathrm{Mg}$ na parte aérea das plantas mostrou-se maior na relação Ca:Mg 2:1. A redução observada nos teores de $\mathrm{Mg}$ na parte aérea pode ser atribuída tanto à diminuição nas quantidades adicionadas, pelo aumento do valor da relação $\mathrm{Ca}: \mathrm{Mg}$, quanto a uma maior competição por um antagonismo entre os dois cátions no processo de absorção (MALAVOLTA, 1980), em detrimento de $\mathrm{Mg}$.

Resultados com tendências similares ao do presente trabalho, foram observados por SILVA (1980); ARANTES (1983); SMITH (1984); GROVE \& SUMMER (1985) e CARMELLO (1989) em milho, MELLO \& KAMINSKY (1990) em aveia, MARUN (1990) em gramíneas forrageiras.

$\mathrm{O}$ efeito das diferentes doses de fósforo aplicadas sobre os teores de $\mathrm{Mg}$ nos tecidos das plantas, mostrou menor concentração de $\mathrm{Mg}$ quando da aplicação da dose de 100 ppm de P, em relação às doses de 0 e 200 ppm (Quadro 17). 
Quando as relações Ca:Mg foram avaliadas para cada saturação por bases (Quadro 40) e para as correspondentes doses de P aplicadas (Quadro 41), constatou-se que os teores de $\mathrm{Mg}$ na parte aérea mostraram o mesmo comportamento observado para a concentração de $\mathrm{Mg}$ na parte aérea sob influência das relações $\mathrm{Ca}: \mathrm{Mg}$. Os teores médios de $\mathrm{Mg}$ decresceram, à medida que se elevou as relações $\mathrm{Ca}: \mathrm{Mg}$ no solo, pelos devidos corretivos.

Quadro 40 - Teores de Mg na matéria seca da parte aérea das plantas de milho (\%), em função das relações Ca:Mg no solo e saturações por bases.

\begin{tabular}{ccc}
\hline \hline Relação & \multicolumn{2}{c}{ Saturação por bases (\%) } \\
\cline { 2 - 3 } Ca:Mg & 50 & 70 \\
\hline $2: 1$ & $0.29 \mathrm{a}$ & $0.46 \mathrm{a}$ \\
$3: 1$ & $0.21 \mathrm{~b}$ & $0.29 \mathrm{~b}$ \\
$4: 1$ & $0.16 \mathrm{c}$ & $0.24 \mathrm{c}$ \\
$5: 1$ & $0.14 \mathrm{c}$ & $0.19 \mathrm{~d}$ \\
\hline
\end{tabular}

D.M.S. $5 \%=0.03$

Médias seguidas da mesma letra, nas colunas, não diferem estatisticamente entre si, pelo teste de Tukey, ao nível de $5 \%$ de probabilidade. 
Quadro 41 - Teores de Mg na matéria seca da parte aérea das plantas de milho (\%), em função das relações $\mathrm{Ca}: \mathrm{Mg}$ no solo e doses de $\mathrm{P}$ aplicadas.

\begin{tabular}{cccc}
\hline \hline Relação & \multicolumn{3}{c}{ Doses de P $\left(\mu \mathrm{g} \cdot \mathrm{cm}^{-3}\right)$} \\
\cline { 2 - 4 } Ca:Mg & 0 & 100 & 200 \\
\hline $2: 1$ & $0.47 \mathrm{a}$ & $0.32 \mathrm{a}$ & $0.35 \mathrm{a}$ \\
$3: 1$ & $0.29 \mathrm{~b}$ & $0.22 \mathrm{~b}$ & $0.25 \mathrm{~b}$ \\
$4: 1$ & $0.25 \mathrm{bc}$ & $0.17 \mathrm{c}$ & $0.19 \mathrm{c}$ \\
$5: 1$ & $0.21 \mathrm{c}$ & $0.12 \mathrm{~d}$ & $0.16 \mathrm{c}$ \\
\hline
\end{tabular}

D.M.S. $5 \%=0.04$

Médias seguidas da mesma letra, nas colunas, não diferem estatisticamente entre si, pelo teste de Tukey, ao nível de $5 \%$ de probabilidade.

Regressões obtidas para as concentrações de $\mathrm{Mg}$ das interações relação Ca:Mg X saturação por bases e relação Ca: $\mathrm{Mg}$ x doses de $\mathrm{P}$ aplicadas no solos.

$$
\begin{array}{ll}
\text { V50 : } y=0,174885 x-0,030399 x^{2} & R^{2}=0,92^{* *} \\
\text { V70 : y }=0,271667 x-0,048635 x^{2} & R^{2}=0,90 * * \\
\text { P0 : y }=0,266959 x-0,046715 x^{2} & R^{2}=0,89 * * \\
\text { P100:y }=0,193818 x-0,034976 x^{2} & R^{2}=0,92 * * \\
\text { P200:y }=0,209052 x-0,036860 x^{2} & R^{2}=0,90 * *
\end{array}
$$


Analisando-se o efeito das saturações por bases e das respectivas doses de $\mathrm{P}$ estudadas, verifica-se que a influência foi significativa em todos os casos (Quadro 42). Constata-se uma tendência de redução no teor de $\mathrm{Mg}$ com o aumento dos níveis de $\mathrm{P}$ aplicados, atingindo-se os valores mínimos na dose de 100 ppm de P. As concentrações de $\mathrm{Mg}$ para a saturação por bases de $70 \%$ foram superiores àquelas encontradas para a saturação por bases de $50 \%$.

Quadro 42 - Teores de Mg na matéria seca da parte aérea das plantas de milho (\%), em função das saturações por bases e doses de P aplicadas.

\begin{tabular}{cccc}
\hline Saturação por bases & \multicolumn{3}{c}{ Doses de P $\left(\mu \mathrm{g} \cdot \mathrm{cm}^{-3}\right)$} \\
\cline { 2 - 4 }$\%$ & 0 & 100 & 200 \\
\hline 50 & $0.25 \mathrm{~b}$ & $0.17 \mathrm{~b}$ & $0.19 \mathrm{~b}$ \\
70 & $0.36 \mathrm{a}$ & $0.24 \mathrm{a}$ & $0.28 \mathrm{a}$ \\
\hline D.M.S. 5\% & & & \\
\hline \hline
\end{tabular}

Médias seguidas da mesma letra, nas colunas, não diferem estatisticamente entre si, pelo teste de Tukey, ao nível de $5 \%$ de probabilidade.

No desdobramento da interação saturação por bases x relação Ca: $\mathbf{M g}$ x $\mathbf{P}$, pelo teste de Tukey ao nível de $5 \%$, verifica-se que a influência foi significativa em todos os casos (Quadro 43). A saturação por bases de $70 \%$ e na dose de 0 ppm de P 
proporcionou maior concentração de $\mathrm{Mg}$ na parte aérea das plantas, sendo a relação Ca:Mg 2:1 aquela que mostrou o maior teor de $\mathrm{Mg}$. Entretanto, menor teor de $\mathrm{Mg}$ apresentou-se na saturação por bases de $50 \%$ e na dose de 100 ppm de P, com uma menor concentração na relação $\mathrm{Ca}: \mathrm{Mg} 5: 1$, não diferindo da relação Ca:Mg 4:1.

Quadro 43 - Teores de Mg na matéria seca da parte aérea das plantas de milho (\%), em função dos tratamentos.

\begin{tabular}{ccccc}
\hline Saturação por bases & \multirow{2}{*}{ Relação } & \multicolumn{3}{c}{ Doses de P $\left(\mu \mathrm{g} \cdot \mathrm{cm}^{-3}\right)$} \\
\cline { 3 - 5 }$\%$ & Ca:Mg & 0 & 100 & 200 \\
\hline 50 & $2: 1$ & $0.36 \mathrm{a}$ & $0.26 \mathrm{a}$ & $0.26 \mathrm{a}$ \\
& $3: 1$ & $0.25 \mathrm{~b}$ & $0.19 \mathrm{~b}$ & $0.18 \mathrm{~b}$ \\
& $4: 1$ & $0.21 \mathrm{bc}$ & $0.12 \mathrm{c}$ & $0.16 \mathrm{~b}$ \\
& $5: 1$ & $0.17 \mathrm{c}$ & $0.10 \mathrm{c}$ & $0.15 \mathrm{~b}$ \\
\hline 70 & $2: 1$ & $0.58 \mathrm{a}$ & $0.37 \mathrm{a}$ & $0.43 \mathrm{a}$ \\
& $3: 1$ & $0.33 \mathrm{~b}$ & $0.25 \mathrm{~b}$ & $0.31 \mathrm{~b}$ \\
& $4: 1$ & $0.30 \mathrm{bc}$ & $0.21 \mathrm{~b}$ & $0.22 \mathrm{c}$ \\
\hline & $5: 1$ & $0.26 \mathrm{c}$ & $0.14 \mathrm{c}$ & $0.16 \mathrm{c}$ \\
\hline
\end{tabular}

D.M.S. $5 \%=0.06$

Médias seguidas da mesma letra, nas colunas, não diferem estatisticamente entre si, pelo teste de Tukey, ao nível de $5 \%$ de probabilidade. 
Os resultados da análise de variância (Quadro 6) indicam efeito significativo ao nível de $5 \%$ na acumulação de $\mathrm{Mg}$ na parte aérea para todas as causas de variação. As saturações por bases afetaram significativamente a absorção de $\mathrm{Mg}$ (Quadro 7). Observa-se um acréscimo no acúmulo de $\mathrm{Mg}$ na parte aérea das plantas com o aumento da saturação por bases.

O acúmulo de $\mathrm{Mg}$ na parte aérea foi influenciado pelas relações $\mathrm{Ca}: \mathrm{Mg}$ do solo (Quadro 8). Verifica-se uma redução significativa nas quantidades de $\mathrm{Mg}$ absorvidas, com a diminuição na proporção de $\mathrm{Mg}$ no corretivo (alta relação $\mathrm{Ca}: \mathrm{Mg}$ ). A maior quantidade de $\mathrm{Mg}$ absorvida ocorreu na relação Ca:Mg 2:1. Corretivos com relações $\mathrm{Ca}: \mathrm{Mg}$ estreitas, fornecem mais $\mathrm{Mg}$ e aumentam os teores do nutriente no solo, favorecendo uma competição mais equilibrada com o Ca e a absorção é aumentada. Entretanto, a queda no $\mathrm{Mg}$ acumulado pelas plantas em relações $\mathrm{Ca}: \mathrm{Mg}$ altas, decorrente da diminuição do crescimento das plantas, pode-se atribuir ao efeito depressivo ocasionado por altas doses de carbonato de cálcio e do próprio $\mathrm{Ca}$ na absorção do Mg. O Mg extraído correlacionou-se positivamente com as quantidades acumuladas de $\mathrm{N}\left(\mathrm{r}=0,7125^{* *}\right)$ na parte aérea.

As doses de $\mathbf{P}$ influenciaram a quantidade acumulada de $\mathrm{Mg}$ na parte aérea (Quadro 9). Constata-se um acréscimo na absorção de $\mathrm{Mg}$ com o aumento dos níveis de P. As doses de 100 e 200 ppm de $P$, que não diferiram entre si, foram superiores à dose de $0 \mathrm{ppm}$ ao conferirem maiores valores de $\mathrm{Mg}$ absorvido.

O acúmulo de $\mathrm{Mg}$ em função das relações $\mathrm{Ca}: \mathrm{Mg}$ e saturações por bases, mostrou uma elevação na quantidade acumulada de $\mathrm{Mg}$ com o acréscimo da saturação por bases (Quadro 44). 
Quadro 44 - Quantidade acumulada de Mg na parte aérea das plantas de milho (mg vaso $^{-1}$ ), em função das relações Ca:Mg no solo e saturações por bases.

\begin{tabular}{ccc}
\hline \hline Relação & \multicolumn{2}{c}{ Saturação por bases $(\%)$} \\
\cline { 2 - 3 } Ca:Mg & 50 & 70 \\
\hline $2: 1$ & $53.05 \mathrm{a}$ & $84.05 \mathrm{a}$ \\
$3: 1$ & $37.09 \mathrm{~b}$ & $58.77 \mathrm{~b}$ \\
$4: 1$ & $27.63 \mathrm{c}$ & $45.45 \mathrm{c}$ \\
$5: 1$ & $21.60 \mathrm{c}$ & $31.25 \mathrm{~d}$ \\
\hline
\end{tabular}

D.M.S. $5 \%=8.29$

Médias seguidas da mesma letra, nas colunas, não diferem estatisticamente entre si, pelo teste de Tukey, ao nível de $5 \%$ de probabilidade.

Verificou-se maior absorção na saturação por bases de $70 \%$ e na relação Ca:Mg 2:1, apresentando-se significativamente diferente às demais relações Ca:Mg.

Equações de regressão para a quantidade de $\mathrm{Mg}$ absorvida pelo milho sob influência da interação Ca:Mg no solo x saturação por bases.

$$
\begin{array}{ll}
\text { V50 : } y=31,723839 x-5,735833 x^{2} & R^{2}=0,73^{* *} \\
\text { V70 : } y=51,503454 x-9,369091 x^{2} & R^{2}=0,72^{* *}
\end{array}
$$

Ao avaliar as relações $\mathrm{Ca}: \mathrm{Mg}$ para as doses de $\mathrm{P}$ aplicadas, nota-se um acréscimo no acúmulo de $\mathrm{Mg}$ na parte aérea das plantas com o aumento dos níveis de 
P estudados (Quadro 45). Verifica-se que a influência não foi significativa para a dose de 0 ppm de P. A relação Ca:Mg 2:1 nas doses de 100 e 200 ppm de $\mathrm{P}$ proporcionou a maior quantidade de $\mathrm{Mg}$ absorvida.

Quadro 45 - Quantidade acumulada de Mg na parte aérea das plantas de milho (mg vaso $^{-1}$ ), em função das relações Ca: $\mathrm{Mg}$ no solo e doses de $\mathrm{P}$ aplicadas.

\begin{tabular}{cccc}
\hline \hline Relação & \multicolumn{3}{c}{ Doses de $\mathrm{P}\left(\mu \mathrm{g} \cdot \mathrm{cm}^{-3}\right)$} \\
\cline { 2 - 4 } Ca:Mg & 0 & 100 & 200 \\
\hline $2: 1$ & $14.56 \mathrm{a}$ & $96.12 \mathrm{a}$ & $94.98 \mathrm{a}$ \\
$3: 1$ & $10.45 \mathrm{a}$ & $65.54 \mathrm{~b}$ & $67.80 \mathrm{~b}$ \\
$4: 1$ & $8.56 \mathrm{a}$ & $53.44 \mathrm{c}$ & $47.61 \mathrm{c}$ \\
$5: 1$ & $7.19 \mathrm{a}$ & $34.68 \mathrm{~d}$ & $37.41 \mathrm{~d}$ \\
\hline
\end{tabular}

D.M.S. $5 \%=10.16$

Médias seguidas da mesma letra, nas colunas, não diferem estatisticamente entre si, pelo teste de Tukey, ao nível de $5 \%$ de probabilidade.

Equações de regressão em função das relações $\mathrm{Ca}: \mathrm{Mg}$ no solo e dos níveis de P aplicados no acúmulo de $\mathrm{Mg}$ pela planta.

$$
\begin{aligned}
& \text { P0 : y }=8,460785 x-1,462352 x^{2} \quad R^{2}=0,93^{* *} \\
& \text { P100: y }=58,723532 x-10,737374 x^{2} R^{2}=0,91^{* *} \\
& \text { P200: y }=57,656623 x-10,457660 x^{2} R^{2}=0,88^{* *}
\end{aligned}
$$


A quantidade de $\mathrm{Mg}$ absorvida em relação às saturações por bases e doses de $\mathrm{P}$ aplicadas, mostrou que o aumento dos níveis de $\mathbf{P}$ testados promoveu um acréscimo no acúmulo de $\mathrm{Mg}$ na parte aérea (Quadro 46). A influência não foi significativa para a dose de 0 ppm de P. As doses de 100 e 200 ppm de P na saturação por bases de $70 \%$ proporcionaram maior absorção de $\mathrm{Mg}$.

Quadro 46 - Quantidade acumulada de Mg na parte aérea das plantas de milho (mg vaso $^{-1}$ ), em função das saturações por bases e doses de $\mathrm{P}$ aplicadas.

\begin{tabular}{cccc}
\hline Saturação por bases & \multicolumn{3}{c}{ Doses de $\mathrm{P}\left(\mu \mathrm{g} \cdot \mathrm{cm}^{-3}\right)$} \\
\cline { 2 - 4 }$\%$ & 0 & 100 & 200 \\
\hline 50 & $9.03 \mathrm{a}$ & $50.57 \mathrm{~b}$ & $44.94 \mathrm{~b}$ \\
70 & $11.35 \mathrm{a}$ & $74.32 \mathrm{a}$ & $78.97 \mathrm{a}$ \\
\hline
\end{tabular}

D.M.S. $5 \%=5.44$

Médias seguidas da mesma letra, nas colunas, não diferem estatisticamente entre si, pelo teste de Tukey, ao nível de $5 \%$ de probabilidade.

No desdobramento da interação saturação por bases, relação $\mathrm{Ca}: \mathrm{Mg} \times \mathrm{P}$, constata-se que a influência foi significativa para as doses de 100 e 200 ppm de P, independente das saturações por bases (Quadro 47). Os valores acumulados de $\mathrm{Mg}$ acompanharam a mesma tendência dos teores na parte aérea. Os valores médios 
acumulados de $\mathrm{Mg}$ decresceram com o aumento da relação $\mathrm{Ca}: \mathrm{Mg}$ no solo, sendo que a relação Ca:Mg 2:1 mostrou maiores valores de $\mathrm{Mg}$ absorvido na parte aérea $\mathrm{e}$ diferenciou-se das demais relações nas doses 100 e 200 ppm de P.

Quadro 47 - Quantidade acumulada de Mg na parte aérea das plantas de milho (mg vaso $^{-1}$ ), em função dos tratamentos.

\begin{tabular}{|c|c|c|c|c|}
\hline \multirow{2}{*}{$\begin{array}{c}\text { Saturação por bases } \\
\%\end{array}$} & \multirow{2}{*}{$\begin{array}{l}\text { Relação } \\
\mathrm{Ca}: \mathrm{Mg}\end{array}$} & \multicolumn{3}{|c|}{ Doses de $\mathrm{P}\left(\mu \mathrm{g} . \mathrm{cm}^{-3}\right)$} \\
\hline & & 0 & 100 & 200 \\
\hline \multirow[t]{4}{*}{50} & $2: 1$ & $13.10 \mathrm{a}$ & $76.89 a$ & $69.18 a$ \\
\hline & $3: 1$ & $8.78 \mathrm{a}$ & $56.51 b$ & $46.98 b$ \\
\hline & $4: 1$ & $7.36 \mathrm{a}$ & $36.20 \mathrm{c}$ & $32.34 c$ \\
\hline & $5: 1$ & $5.87 \mathrm{a}$ & $27.69 c$ & $31.25 \mathrm{c}$ \\
\hline \multirow[t]{4}{*}{70} & $2: 1$ & $16.02 \mathrm{a}$ & $115.34 \mathrm{a}$ & $120.77 \mathrm{a}$ \\
\hline & $3: 1$ & $11.11 \mathrm{a}$ & $76.56 b$ & $88.63 b$ \\
\hline & $4: 1$ & $9.76 a$ & $63.68 b$ & $62.89 c$ \\
\hline & $5: 1$ & $8.51 \mathrm{a}$ & $41.68 \mathrm{c}$ & $43.57 \mathrm{~d}$ \\
\hline D.M.S. $5 \%=14.37$ & & & & \\
\hline
\end{tabular}

Médias seguidas da mesma letra, nas colunas, não diferem estatisticamente entre si, pelo teste de Tukey, ao nível de $5 \%$ de probabilidade. 


\subsubsection{Teores na parte aérea das plantas e $\mathrm{S}$ absorvido}

Pela análise de variância, nota-se que as saturações por bases, relações Ca: $\mathrm{Mg}$, doses de $\mathrm{P}$ e as interações saturação por bases x relação $\mathrm{Ca}: \mathrm{Mg}$ e relação $\mathrm{Ca}: \mathrm{Mg}$ x $\mathrm{P}$ influenciaram significativamente ao nível de $1 \%$ o teor de S na parte aérea das plantas (Quadro 14).

Quanto aos valores dos teores nos tecidos em função das saturações por bases (Quadro 15), evidencia-se que o aumento da saturação por bases promoveu uma redução no teor de $\mathrm{S}$ nos tecidos das plantas.

O teor de $\mathbf{S}$ na parte aérea foi influenciado significativamente pelas relações Ca:Mg no solo (Quadro 16). Verifica-se uma tendência de redução na concentração de $\mathrm{S}$ nos tecidos das plantas, à medida que se aumenta o valor da relação $\mathrm{Ca}: \mathrm{Mg}$ no solo. Esses resultados são concordantes com os obtidos por CARMELLO (1989), que observou uma redução de forma quadrática nos teores de $\mathrm{S}$ no tecido de milho. Entretanto, MARUN (1990) não verificou influência das relações Ca:Mg no solo nas concentrações de S na parte aérea das plantas de milho.

Com relação aos teores de $\mathrm{S}$ no milho, em função das doses de $\mathrm{P}$ aplicadas, observa-se o aumento dos níveis de $\mathrm{P}$ tendeu a promover uma redução na concentração de S nas plantas (Quadro 17). A dose de $100 \mathrm{ppm}$ de $\mathrm{P}$, que apresentou o menor teor de $\mathrm{S}$ na parte aérea das plantas, diferenciou-se das demais doses de $\mathrm{P}$.

Avaliando o efeito das relações Ca:Mg e das saturações por bases, verifica-se que a influência não foi significativa para a saturação por bases de $70 \%$ (Quadro 48). A saturação por bases de $50 \%$ na relação $\mathrm{Ca}: \mathrm{Mg} 2: 1$ proporcionou maior teor de $\mathrm{S}$ nos tecidos e mostrou-se significativamente diferente às demais relações $\mathrm{Ca}: \mathrm{Mg}$ estudadas. 
Quadro 48 - Teores de S na matéria seca da parte aérea das plantas de milho (\%), em função das relações Ca:Mg no solo e saturações por bases.

\begin{tabular}{ccc}
\hline \hline Relação & \multicolumn{2}{c}{ Saturação por bases (\%) } \\
\cline { 2 - 3 } Ca:Mg & 50 & 70 \\
\hline $2: 1$ & $0.18 \mathrm{a}$ & $0.15 \mathrm{a}$ \\
$3: 1$ & $0.16 \mathrm{~b}$ & $0.14 \mathrm{a}$ \\
$4: 1$ & $0.15 \mathrm{bc}$ & $0.14 \mathrm{a}$ \\
$5: 1$ & $0.14 \mathrm{c}$ & $0.15 \mathrm{a}$ \\
\hline
\end{tabular}

D.M.S. $5 \%=0.01$

Médias seguidas da mesma letra, nas colunas, não diferem estatisticamente entre si, pelo teste de Tukey, ao nível de $5 \%$ de probabilidade.

Equações de regressão para teor de S nas plantas sob influência das relações Ca:Mg x das saturações por bases.

$$
\begin{array}{ll}
V 50: y=0,1066597 x-0,0162095 x^{2} & R^{2}=0,96^{* *} \\
V 70: y=0,0885647 x-0,0121103 x^{2} & R^{2}=0,96^{* *}
\end{array}
$$

Quando se analisou o efeito das relações Ca:Mg e das doses de P, constatou-se que a influência não foi significativa para a dose de 200 ppm de P (Quadro 49). A dose 0 ppm de $\mathbf{P}$ conferiu maior concentração de $S$ na parte aérea das plantas. A relação 
Ca:Mg 2:1 destacou-se ao mostrar maior teor nos tecidos que as relações Ca:Mg 3:1, 4:1 e 5:1, as quais não diferiram entre si.

Quadro 49 - Teores de S na matéria seca da parte aérea das plantas de milho (\%), em função das relações Ca:Mg no solo e doses de $\mathrm{P}$ aplicadas.

\begin{tabular}{cccc}
\hline \hline Relação & \multicolumn{3}{c}{ Doses de P $\left(\mu \mathrm{g} . \mathrm{cm}^{-3}\right)$} \\
\cline { 2 - 4 } Ca:Mg & 0 & 100 & 200 \\
\hline $2: 1$ & $0.21 \mathrm{a}$ & $0.14 \mathrm{a}$ & $0.14 \mathrm{a}$ \\
$3: 1$ & $0.17 \mathrm{~b}$ & $0.13 \mathrm{ab}$ & $0.15 \mathrm{a}$ \\
$4: 1$ & $0.16 \mathrm{~b}$ & $0.11 \mathrm{~b}$ & $0.15 \mathrm{a}$ \\
$5: 1$ & $0.15 \mathrm{~b}$ & $0.12 \mathrm{ab}$ & $0.15 \mathrm{a}$ \\
\hline
\end{tabular}

D.M.S. $5 \%=0.02$

Médias seguidas da mesma letra, nas colunas, não diferem estatisticamente entre si, pelo teste de Tukey, ao nível de 5\% de probabilidade.

Equações de regressão e respectivos coeficientes de determinação para as concentrações de $\mathrm{S}$ na matéria seca das plantas de milho, em função das relações $\mathrm{Ca}: \mathrm{Mg}$ em interação com as doses de $\mathrm{P}$ aplicadas no solo. 


$$
\begin{array}{ll}
\text { P0 : } y=0,1227125 x-0,0188648 x^{2} & R^{2}=0,97 * * \\
\text { P100: } y=0,0826526 x-0,0120419 x^{2} & R^{2}=0,98 * * \\
\text { P200: } y=0,0874715 x-0,0115730 x^{2} & R^{2}=0,99 * *
\end{array}
$$

A análise de variância revelou efeito significativo ao nível de 5\% para todas as causas de variação sobre a acumulação de $S$ na parte aérea (Quadro 6).

Constata-se um acréscimo no acúmulo de $\mathrm{S}$ nos tecidos com o aumento de saturação por bases (Quadro 7).

As relações $\mathrm{Ca}: \mathrm{Mg}$ diferenciaram entre si quanto às quantidades de $\mathrm{S}$ absorvidas (Quadro 8). Verifica-se uma tendência de redução na absorção de S quando a proporção de $\mathrm{Ca}$ no corretivo foi aumentada. As relações Ca:Mg 2:1 e 3:1 proporcionaram maior acúmulo de $S$ na planta que as relações Ca:Mg 5:1 e 4:1, as quais não diferiram entre si. Resultados com tendências semelhantes foram observados em gramíneas forrageiras por MARUN (1990).

$\mathrm{O}$ acúmulo de $\mathrm{S}$ na parte aérea sob influência das doses de $\mathrm{P}$ aplicadas variou de forma significativa, à medida que os níveis de $\mathrm{P}$ foram aumentados (Quadro 9). As doses de 100 e 200 ppm, que não diferiram entre si, mostraram maior quantidade de $\mathrm{S}$ absorvido que a dose de $0 \mathrm{ppm}$ de $\mathrm{P}$.

Ao avaliar o efeito das relações $\mathrm{Ca}: \mathrm{Mg}$ para cada saturação por bases, verificase que apenas na saturação por bases de 50\%, as relações $\mathrm{Ca}: \mathrm{Mg}$ mostraram efeito significativo na absorção de $\mathrm{S}$, causando decréscimos neste parâmetro, à medida em que se aumenta a proporção de $\mathrm{Ca}$ no corretivo (Quadro 50 ). A relação $\mathrm{Ca}: \mathrm{Mg} 2: 1$ se 
destacou ao fornecer maior acúmulo de $\mathrm{S}$ que as relações $\mathrm{Ca}: \mathrm{Mg}$ 3:1, 4:1 e 5:1, as quais não diferiram entre si.

Quadro 50 - Quantidade acumulada de S na parte aérea das plantas de milho (mg vaso $^{-1}$ ), em função das relações Ca: $\mathrm{Mg}$ no solo e saturações por bases.

\begin{tabular}{ccc}
\hline \hline Relação & \multicolumn{2}{c}{ Saturação por bases (\%) } \\
\cline { 2 - 3 } Ca:Mg & 50 & 70 \\
\hline $2: 1$ & $31.01 \mathrm{a}$ & $26.89 \mathrm{a}$ \\
$3: 1$ & $28.22 \mathrm{~b}$ & $28.74 \mathrm{a}$ \\
$4: 1$ & $23.64 \mathrm{c}$ & $26.40 \mathrm{a}$ \\
$5: 1$ & $22.49 \mathrm{c}$ & $27.88 \mathrm{a}$ \\
\hline
\end{tabular}

D.M.S. $5 \%=2.52$

Médias seguidas da mesma letra, nas colunas, não diferem estatisticamente entre si, pelo teste de Tukey, ao nível de $5 \%$ de probabilidade.

Equações de regressão para os valores de $\mathrm{S}$ absorvidos em função das relações Ca:Mg no solo em interação com as saturações por bases.

$$
\begin{array}{ll}
\text { V50 : } y=19,305840 x-3,070265 x^{2} & R^{2}=0,76^{* *} \\
\text { V70 : } y=16,614026 x-2,287163 x^{2} & R^{2}=0,74 * *
\end{array}
$$


$O$ acúmulo de $S$ na parte aérea foi influenciado significativamente pelas relações Ca: $\mathrm{Mg}$ nas doses 100 e 200 ppm de P (Quadro 51). As relações Ca:Mg 2:1 e 3:1 para as doses 100 e $200 \mathrm{ppm}$ de $\mathrm{P}$ proporcionaram maior quantidade de $\mathrm{S}$ absorvida que as relações Ca:Mg 5:1 e 4:1, as quais não diferiram entre si.

Quadro 51 - Quantidade acumulada de S na parte aérea das plantas de milho (mg vaso $^{-1}$ ), em função das relações $\mathrm{Ca}: \mathrm{Mg}$ no solo e doses de $\mathrm{P}$ aplicadas.

\begin{tabular}{cccc}
\hline \hline Relação & \multicolumn{3}{c}{ Doses de P $\left(\mu \mathrm{g} \cdot \mathrm{cm}^{-3}\right)$} \\
\cline { 2 - 4 } Ca:Mg & 0 & 100 & 200 \\
\hline $2: 1$ & $6.27 \mathrm{a}$ & $42.28 \mathrm{a}$ & $37.85 \mathrm{ab}$ \\
$3: 1$ & $5.83 \mathrm{a}$ & $38.70 \mathrm{~b}$ & $40.92 \mathrm{a}$ \\
$4: 1$ & $5.44 \mathrm{a}$ & $32.92 \mathrm{c}$ & $36.71 \mathrm{~b}$ \\
$5: 1$ & $5.27 \mathrm{a}$ & $34.34 \mathrm{c}$ & $35.87 \mathrm{~b}$ \\
\hline
\end{tabular}

D.M.S. $5 \%=3.09$

Médias seguidas da mesma letra, nas colunas, não diferem estatisticamente entre si, pelo teste de Tukey, ao nível de 5\% de probabilidade.

Equações de regressão para a quantidade acumulada de $S$ na parte aérea do milho sob influência das relações $\mathrm{Ca}: \mathrm{Mg}$ e os níveis de $\mathrm{P}$ adicionados ao solo. 


$$
\begin{array}{ll}
P 0: y=3,993585 x-0,609686 x^{2} & R^{2}=0,96^{* *} \\
\text { P100: y }=25,508888 x-3,892277 x^{2} & R^{2}=0,98^{* *} \\
\text { P200 : y }=24,377325 x-3,534180 x^{2} & R^{2}=0,98^{* *}
\end{array}
$$

Quando se analisou o efeito das saturações por bases e das doses de P testadas, verificou-se que apenas na dose de 200 ppm de $P$, as saturações por bases mostraram efeito significativo na quantidade acumulada de $S$ na parte aérea (Quadro 52). A dose de 200 ppm de Pproporcionou a maior quantidade de $\mathrm{S}$ absorvida, sendo que o acúmulo de S pela planta para a saturação por bases de $70 \%$ foi superior àquele encontrado para a saturação por bases de $50 \%$.

Quadro 52 - Quantidade acumulada de S na parte aérea das plantas de milho (mg vaso $^{-1}$ ), em função das saturações por bases e doses de $\mathrm{P}$ aplicadas.

\begin{tabular}{cccc}
\hline \hline Saturação por bases & \multicolumn{3}{c}{ Doses de P $\left(\mu \mathrm{g} . \mathrm{cm}^{-3}\right)$} \\
\cline { 2 - 4 }$\%$ & 0 & 100 & 200 \\
\hline 50 & $6.26 \mathrm{a}$ & $36.39 \mathrm{a}$ & $36.37 \mathrm{~b}$ \\
70 & $5.37 \mathrm{a}$ & $37.73 \mathrm{a}$ & $39.30 \mathrm{a}$ \\
\hline
\end{tabular}

D.M.S. $5 \%=1.65$

Médias seguidas da mesma letra, nas colunas, não diferem estatisticamente entre si, pelo teste de Tukey, ao nível de $5 \%$ de probabilidade. 
$\mathrm{O}$ desdobramento da interação saturação por bases $\mathrm{x}$ relação Ca:Mg x $\mathrm{P}$ verificou uma influência significativa das doses 100 e 200 ppm de $P$ nas duas saturações por bases (Quadro 53). As relações Ca:Mg 2:1 e 3:1 da saturação por bases de 50\% nas doses 100 e $200 \mathrm{ppm}$ de $\mathrm{P}$ e na dose $100 \mathrm{ppm}$ de $\mathrm{P}$ da saturação por bases de $70 \%$ mostraram uma maior quantidade de $\mathbf{S}$ absorvida.

Quadro 53 - Quantidade acumulada de S na parte aérea das plantas de milho (mg vaso $\left.^{-1}\right)$, em função dos tratamentos.

\begin{tabular}{ccccc}
\hline \hline Saturação por bases & Relação & \multicolumn{3}{c}{ Doses de P $\left(\mu \mathrm{g} . \mathrm{cm}^{-3}\right)$} \\
\cline { 3 - 5 }$\%$ & Ca:Mg & 0 & 100 & 200 \\
\hline 50 & $2: 1$ & $7.97 \mathrm{a}$ & $42.69 \mathrm{a}$ & $42.37 \mathrm{a}$ \\
& $3: 1$ & $6.50 \mathrm{a}$ & $39.18 \mathrm{~b}$ & $40.00 \mathrm{a}$ \\
& $4: 1$ & $5.67 \mathrm{a}$ & $32.91 \mathrm{c}$ & $32.34 \mathrm{~b}$ \\
& $5: 1$ & $4.91 \mathrm{a}$ & $31.78 \mathrm{c}$ & $30.77 \mathrm{~b}$ \\
\hline 70 & $2: 1$ & $5.47 \mathrm{a}$ & $41.87 \mathrm{a}$ & $33.32 \mathrm{~b}$ \\
& $3: 1$ & $5.17 \mathrm{a}$ & $39.22 \mathrm{ab}$ & $41.84 \mathrm{a}$ \\
& $4: 1$ & $5.20 \mathrm{a}$ & $32.92 \mathrm{c}$ & $41.07 \mathrm{a}$ \\
& $5: 1$ & $5.62 \mathrm{a}$ & $36.90 \mathrm{bc}$ & $40.97 \mathrm{a}$ \\
\hline
\end{tabular}

D.M.S. $5 \%=4.37$

Médias seguidas da mesma letra, nas colunas, não diferem estatisticamente entre si, pelo teste de Tukey, ao nível de 5\% de probabilidade. 


\section{5 - CONCLUSÕES}

Nas condições em que foi desenvolvido este experimento, os dados obtidos no presente trabalho permitem concluir que:

1 - A produção de matéria seca do milho foi influenciada positivamente pela saturação por bases e pelas doses de $\mathrm{P}$, e negativamente pelo aumento da relação $\mathrm{Ca}: \mathrm{Mg}$ no solo.

Os efeitos das relações Ca: $\mathrm{Mg}$ sobre a produção, mostraram que teores de Ca no corretivo, em relações Ca: $\mathrm{Mg}$ maiores que 3:1, causaram quedas no crescimento e na produção das plantas, em razão do efeito antagônico que tem o Ca na absorção do Mg.

2 - $\mathrm{O}$ teor de $\mathrm{N}$ diminuiu em função da saturação por bases e das doses de $\mathrm{P}$ adicionadas.

As quantidades acumuladas desse nutriente diminuíram com a saturação por bases e aumentaram com a dose de P. 
3 - $\mathrm{O}$ teor e quantidade de $\mathrm{P}$ absorvido foram crescentes quando relacionados com a saturação por bases e doses de $\mathrm{P}$ aplicadas.

4 - $\mathrm{O}$ teor de $\mathrm{K}$ nos tecidos das plantas diminuiu com as relações $\mathrm{Ca}: \mathrm{Mg}$ no solo e as doses de $\mathbf{P}$ aplicadas.

$\mathrm{O}$ conteúdo de $\mathrm{K}$ na parte aérea das plantas aumentou com as doses de $\mathrm{P}$ adicionadas ao solo.

5 - A concentração de Ca na parte aérea das plantas aumentou com a saturação por bases e a relação Ca:Mg no solo e diminuiu com as doses de $\mathrm{P}$ adicionadas.

As quantidades desse nutriente acumuladas pelas plantas, aumentaram com a saturação por bases, com a relação $\mathrm{Ca}: \mathrm{Mg}$ no solo e com as doses de $\mathrm{P}$ aplicadas. O acréscimo no teor e conteúdo de Ca na parte aérea das plantas foi ocasionado pela maior quantidade de carbonato de cálcio aplicado, por dose de corretivo.

6 - Os teores e quantidades de $\mathrm{Mg}$ absorvidas decresceram quando relacionados com as relações Ca:Mg no solo e aumentaram em função da saturação por bases, enquanto a concentração no tecido das plantas diminuiu e as quantidades do nutriente absorvidas aumentaram com o P aplicado no solo.

Elevadas concentrações de Ca no solo, devido às altas aplicações de carbonato de cálcio, tiveram efeito depressivo sobre o teor e conteúdo de $\mathrm{Mg}$ na parte aérea das plantas, ocasionado pelo antagonismo do Ca na absorção do $\mathrm{Mg}$. 
7 - A concentração de $\mathrm{S}$ diminuiu com a saturação por bases, a relação $\mathrm{Ca}: \mathrm{Mg}$ no solo e as doses de $\mathrm{P}$ adicionadas ao solo. As quantidades desse nutriente acumuladas, aumentaram com a saturação por bases e as doses de $\mathrm{P}$ aplicadas e diminuíram com a relação $\mathrm{Ca}: \mathrm{Mg}$ no solo.

8 - A produção de matéria seca, os teores nas plantas e a quantidade acumulada dos nutrientes na parte aérea do milho, mostraram variações significativas quando relacionadas com as combinações de saturação por bases, relação Ca: $\mathrm{Mg}$ e doses de $\mathbf{P .}$

9 - As doses de P testadas influíram nos efeitos das relações Ca:Mg e das saturações por bases sobre a produção de matéria seca. A produção de tecido na parte aérea das plantas foi maior com a dose de 100 ppm de $P$ e na saturação por bases de $70 \%$.

10 - A saturação por bases, as relações Ca: $\mathrm{Mg}$ nos corretivos e a adubação fosfatada do solo utilizado, afetaram o crescimento e a nutrição mineral do milho. $\mathrm{O}$ teor nos tecidos e o acúmulo de nutrientes foram influenciados pela disponibilidade de nutrientes para as plantas, bem como pelo equilíbrio entre os mesmos no solo.

11 - Nas condições do presente experimento, em cultura de milho deve ser indicado o uso de calcário dolomítico.

12 - A correção da acidez do solo, a relação $\mathrm{Ca}: \mathrm{Mg}$ do corretivo e a adubação fosfatada devem ser práticas a serem ajustadas às necessidades da cultura. 


\section{REFERÊNCIAS BIBLIOGRÁFICAS}

ADAMS, F. \& HENDERSON, J.B. Magnesium availability as affected by deficient and adequate levels of potassium and lime. Soil Science Society of America Proceedings, Madison, 26(1):65-8, Jan./Feb. 1962.

ADAMS, F. \& ODON, J.W. Effects of $\mathrm{pH}$ and phosphorus rates on soil-solution phosphorus and phosphorus availability. Soil Science, Baltimore, 140(3):202-5, Sept. 1985.

ANGHINONI, I. \& BARBER, S.A. Phosphorus application rate and distribution in the soil and the phosphorus uptake by corn. Soil Science Society of America Journal, Madison, 44(5):1041-4, Sept./Oct. 1980a.

ANGHINONI, I. \& BARBER, S.A. Phosphorus influx and growth characteristics by corn roots as influenced by phosphorus supply. Soil Science Society of America Journal, Madison, 72(4):685-9, July/Aug. 1980b. 
ARANTES, E.M. Efeito da relação $\mathrm{Ca} / \mathrm{Mg}$ do corretivo e níveis de potássio na produção de matéria seca, concentração de $\mathrm{K}, \mathrm{Ca}, \mathrm{Mg}$ e equilíbrio catiônico do milho (Zea mays (L.). Lavras, 1983. 62p. (Mestrado - Escola Superior de Agricultura de Lavras).

ARAÚJO, J.P. Efeito da calagem na produção de massa seca de soja (Glycine max (L.) Merrill), em três latossolos sob cerrado: quantidade e relação $\mathrm{CaO}: \mathrm{MgO}$ do corretivo. Lavras, 1977. 86p. (Mestrado - Escola Superior de Agricultura de Lavras).

BAUMGARTNER, J.G. Influência da calagem e da adubação fosfatada, sobre a solubilidade e aproveitamento do zinco adicionado ao solo. Piracicaba, 1974. 45p. (Mestrado - Escola Superior de Agricultura "Luiz de Queiroz"/USP).

BESEDIN, P.N. Effect of various ratios of absorved calcium and magnesium on some properties of serozems and plant yields. Trudy nauchnoissled. Inst. Pochv. qos. Kom. Khlopkovod. sred. Azii Goslane, Moskva, 4:68-63, 1965. Apud Soils and Fertilizers, Harpenden, 29(1): 27, Feb. 1966. (Resumo).

BRIENZA JÚNIOR, S. Níveis críticos de fósforo e de enxofre em plantas de sorgo e em dois latossolos com níveis variáveis de fertilidade. Viçosa, 1988. 68p. (Mestrado - Universidade Federal de Viçosa). 
BUCKMAN, H.O. \& BRADY, N.C. The nature and properties fo soils. 8.ed. New York, Mac Millan Publishing Co, 1974. 639p.

BULL, L.T. Influência da relação $\mathrm{K} /(\mathrm{Ca}+\mathrm{Mg})$ do solo na produção de matéria seca e na absorção de potássio por gramínea e leguminosa forrageiras. Piracicaba, 1986. 107p. (Doutorado - Escola Superior de Agricultura "Luiz de Queiroz"/USP).

CALDWELL, C.R. \& HAUG, A. Divalent cation inhibition of barbey root plasma membrane-bound $\mathrm{Ca}^{2+}$ - ATP ase activity and its reversal by monovalent cations. Physiologya Plantarum, Copenhagen, 54(1):112-8, 1982.

CARMELLO, Q.A.C. Saturação por bases e relações entre $\mathrm{K}, \mathrm{Ca}$ e $\mathrm{Mg}$ do solo na nutrição potássica do milho (Zea mays L.) cv. Piranão. Piracicaba, 1989. 103p. (Doutorado - Escola Superior de Agricultura "Luiz de Queiroz"/USP).

CASTILHOS, D.D. \& ANGHINONI, I. Eficiência na absorção e disponibilidade de fósforo pelo milho em relação ao método de aplicação do fertilizante ao solo. Agronomia Sulriograndense, Porto Alegre, 19:43-55, 1983.

CASTILHOS, D.D. \& ANGHINONI, I. Influência do suprimento de fósforo a diferentes frações do sistema radicular sobre o comportamento do milho. Revista Brasileira de Ciência do Solo, Campinas, 12(3):263-7, set./dez. 1988. 
CHAVES SOLERA, M.A. Efeitos de relações Ca:Mg, utilizando carbonatos e sulfatos, sobre o crescimento e a nutrição mineral da cana-de-açúcar. Viçosa, 1988. 186p. (MESTRADO - Universidade Federal de Viçosa).

CLARKSON, A.T. \& SANDERSON, J. Sites of absorption and translocation of iron in barley roots. Tracer and microautoradiographic studies. Plant Physiology, Bethesda, 61(5):731-6, May 1978.

COELHO, F.S. \& VERLENGIA, F. Fertilidade do solo. Campinas, Instituto Campineiro de Ensino Agrícola, 1973. 384p.

CRAVO, M.S. A interação fósforo $x$ enxofre na produção de matéria seca de soja (Glycine max (L.) Merrill) e nos níveis críticos, em três solos de Minas Gerais, com ou sem calagem. Viçosa, 1984, 73p. (Mestrado - Universidade Federal de Viçosa).

CRISTENSON, D.R.; WHITE, R.P.; DOLL, E.C. Yields and magnesium uptake by plants as affected by soil pH and calcium levels. Agronomy Journal, Madison, 65(2):205-6, Mar./Apr. 1973.

DURRANT, M.J. \& DRAYCOTT, A.P. Uptake of magnesium and other fertilizers elements by sugar beet growth on sandy soils. Journal of Agricultural Science, Cambridge, 77:61-8, Aug. 1971. 
EMPRESA BRASILEIRA DE PESQUISA AGROPECUÁRIA. Centro Nacional de Pesquisa do Milho e do Sorgo. Cultura do milho. Brasília, 1983. 85p.

EPSTEIN, E. Nutrição mineral das plantas: princípios e perspectivas. São Paulo, EDUSP, 1975. 341p.

FARINA, M.P.W.; SUMMER, M.E.; PLANK, C.O.; LETZCH, W.S. Effect of pH on soil magnesium and its absortion by corn. Communications in Soil Science and Plant Analysis, New York, 11(10):981-92, 1980.

FASSBENDER, H.W. Química de suelos; con énfasis en suelos de América Latina. San José, IICA, 1984. 422p.

FERREIRA, M.E.; LIMA, L.M.S.; SOUZA, E.A. Efeito do fósforo e do calcário na produção de soja (Glycine max (L.) Merrill) cv. IAC-2 cultivado num solo sob vegetação de cerrado. In: SEMINÁRIO NACIONAL DE PESQUISA DE SOJA, 1., Londrina, 1979. Resumos. Londrina, EMBRAPA-CNPsoja, 1979. p.219-23.

FERRI, M.G. Fisiologia vegetal. São Paulo, EPU, 1985. v.1, 362p.

GALLO, J.R.E.; CATANI, R.A.; GARGANTINI, H. Efeito de três tipos de calcário na reação do solo e no desenvolvimento de soja. Bragantia, Campinas, 15(12):121-9, jun. 1956. 
GOMES, F.P. Curso de estatística experimental. 13.ed. São Paulo, Nobel, 1990. 498p.

GROVE, J.H. \& SUMMER, M.E. Lime induced magnesium stress in corn: impact and phosphorus availability. Soil Science Society of America Journal, Madison, 49(5):1192-6, Sept./Oct. 1985.

GROVE, J.H.; SUMMER, M.E.; SYERS, J.K. Effect of lime and exchangeable magnesium in variable surface change soils. Soil Science Society of America Journal, Madison, 45(3):497-500, May/June 1981.

HALSTEAD, R.L.; McLEAN, A.J.; NIELSEN, K.F. Ca:Mg ratios in soil and the yield and composition of alfalfa. Canadian Journal of Soil Science, Ottawa, 38:85-93, 1958.

HAYNES, R.J. Effects of liming and phosphate availability in acid soils. Plant and Soil, The Hague, 68(3):289-308, 1982.

HERRERA ESTRADA, J.S. Efeito da aplicação de fosfato e calcário sobre a produção de matéria seca de feijão (Phaseolus vulgaris, L.) em cinco latossolos de Minas Gerais. Viçosa, 1984. 43p. (Mestrado - Universidade Federal de Viçosa). 
JASKOWISKY, R.C.M. Effect of different magnesium content in liming materials on some soil properties and on $\mathrm{CaO}$ and $\mathrm{MgO}$ uptake by oats. Pam. Pudavsky, 37:215-24, 1969. Apud Soils and Fertilizers, Harpenden, 33(6):608, Dec. 1970. (Resumo).

JUO, A.S.R. \& UZO, D.F. Liming and interactions in two ultisoils from southern Nigeria. Plant and Soil, The Hague, 47(2):419-30, June 1977.

KEY, J.L.; KUNTZ, L.T.; TUCKER, B.B. Influence of ratio of exchangeable calcium-magnesium on yield and composition of soybean and corn. Soil Science, Baltimore, 93(4):265-79, Apr. 1962.

KHASAWNEH, F.E. Solution ion activity and plant growth. Soil Science Society of America Proceedings, Madison, 35(3):426-36, May/June 1971.

KIEHL, E.J. Manual de edafologia; relações solo-planta. São Paulo, Agronômica Ceres, 1979. 262p.

KUNISH, H.M. Combined effects of lime, phosphate fertilizer and aluminum on plant yield from an acid soil of the southeastern United States. Soil Science, Baltimore, 134(4):233-8, Oct. 1982. 
KURIHARA, C.H. Nutrição mineral e crescimento da soja sob influência do equilíbrio entre Ca, Mg e K. Lavras, 1991. 95p. (Mestrado - Escola Superior de Agricultura de Lavras).

LIMA, J.A. Efeito das relações $\mathrm{Ca} / \mathrm{Mg}$ e $(\mathrm{Ca}+\mathrm{Mg}) / \mathrm{K}$ na correção da acidez de dois latossolos e na produção de matéria seca do tomateiro (Lycopersicum esculentum Mill) cv. "Kada". Viçosa, 1979. 34p. (Mestrado - Universidade Federal de Viçosa).

LOPES, A.S. Solos sob cerrado; características, propriedades e manejo. 2.ed. Piracicaba, Associação Brasileira para Pesquisa da Potassa e do Fosfato, 1984. $162 p$.

MALAVOLTA, E. Elementos de nutrição mineral de plantas. São Paulo, Agronômica Ceres, 1980. 251p.

MALAVOLTA, E. Manual de calagem e adubação das principais culturas. São Paulo, Agronômica Ceres, 1987. 469p.

MAlavoltA, E. ABC da adubação. 5.ed. São Paulo, Agronômica Ceres, 1989. $292 p$. 
MALAVOLTA, E. ABC da análise de solos e folhas. São Paulo, Agronômica Ceres, 1992. 124p.

MALAVOLTA, E. \& DANTAS, J.P. Nutrição e adubação do milho. In: PATTERNIANI, E. \& VIEGAS, G.P., ed. Melhoramento e produção do milho. 2.ed. Campinas, Fundação Cargill, 1987. v.2, p.541-93.

MAlavoltA, E.; VITTI, G.C.; OlIVEIRA, S.A. de. Avaliação do estado nutricional das plantas; princípios e aplicações. Piracicaba, Associação Brasileira para Pesquisa da Potassa e do Fosfato, 1989. 201p.

MALAVOLTA, E.; HAAG, H.P.; MELLO, F.A.F. de; BRASIL SOBRINHO, M.O.C. Nutrição mineral e adubação de plantas cultivadas. São Paulo, Pioneira, 1974. 752p.

MARSCHNER, H. Mineral nutrition of higher plants. London, Academic Press, 1986. 674p.

MARUN, F. Produção de matéria seca e nutrição mineral de gramíneas forrageiras em função da relação Ca:Mg do corretivo. Lavras, 1990. 84p. (Mestrado - Escola Superior de Agricultura de Lavras). 
MELLO, F.A.F. de; BRASIL SOBRINHO, M.O.C. de; ARZOLLA, S.; SILVEIRA, R.I.; COBRA NETTO, A.; KIEHL, J.C. Fertilidade do solo. 3.ed. Piracicaba, Nobel, 1989. 400p.

MELLO, J.W.V. \& KAMINSKY, J. Relações cálcio-magnésio em corretivos de acidez e doses de potássio no solo. 1. Efeito sobre o rendimento de matéria seca e acumulação de $\mathrm{Ca}, \mathrm{Mg}$ e $\mathrm{K}$ na aveia. Revista do Centro de Ciências Rurais, Santa Maria, 20(1/2):113-24, 1990.

MENGEL, E. \& KIRBY, E.A. Principles of plant nutrition. 4.ed. Bern, International Potash Institute, 1987. 687p.

MICHAEL, A.W. \& ELLIS, B.G. Influence of calcium solution activity and surface area on the solubility of selected rock phosphates. Soil Science, Baltimore, 138(5):354-9, Nov. 1984

MUCHOVEJ, R.M.C. Efeito de níveis de corretivo em diferentes relações Ca:Mg sobre o comportamento de soja (Glycine max (L.) Merrill). Viçosa, 1980. 38p. (Mestrado - Universidade Federal de Viçosa).

NOVAIS, R.F.; FERREIRA, R.P.; NEVES, J.C.L.; BARROS, N.F. Absorção de fósforo e crescimento do milho com sistema radicular parcialmente exposto a fonte de fósforo. Pesquisa Agropecuária Brasileira, Brasília, 20(7):749-54, July 1985. 
OGANGO, K.O. \& TEYKER, R.H. Effect of lime rate on corn root characteristics under enhanced ammonium supply. Journal of Plant Nutrition, New York, 14(7): 663-73, July 1991.

PAVAN, M.A.; BINGHAM, F.T.; PERYEA, F.G. Influence of calcium and magnesium salts on acid soil and chemistry and calcium nutrition of apple. Soil Science Society of America Journal, Madison, 51(6):1526-30, Nov./Dec. 1987.

PECK, N.H. \& MacDONALD, G.E. Sweet corn plant responses to $\mathrm{P}$ and $\mathrm{K}$ in the soil and to band-applied monoammonium phosphate, potassium sulfate, and magnesium sulfate. Journal of the American Society for Horticultural Science, Alexandria, 114(2):269-72, Mar. 1989.

PEIXOTO, A.A. Efeitos do cálcio, magnésio e potássio e suas relações na produção de cana-de-açúcar (Saccharum spp.) em um solo gley húmico do norte fluminense. Viçosa, 1980. 48p. (Mestrado - Universidade Federal de Viçosa).

PIMENTEL, K.F. Aprofundamento do sistema radicular de cana-de-açúcar em colunas de solo com diferentes níveis de cálcio. Viçosa, 1986. 44p. (Mestrado Universidade Federal de Viçosa). 
QUAGGIO, J.A. \& RAIJ, B. van. Comparação de métodos rápidos para a determinação da matéria orgânica em solos. Revista Brasileira de Ciência do Solo, Campinas, 3(3):184-7, set./dez. 1979.

RAIJ, B. van. Dinâmica e disponibilidade de fósforo no solo. In: CURSO DE ATUALIZAÇÃO EM FERTILIDADE DO SOLO, 1., Ilha Solteira, 1987. Trabalhos apresentados. Campinas, Fundação Cargill, 1987. cap.6, p.161-79.

RAIJ, B. van. Fertilidade do solo e adubação. São Paulo, Agronômica Ceres, 1991. $343 p$.

REICHARDT, K. Dinâmica de íons no solo. In: SIMPÓSIO AVANÇADO DE QUÍMICA E FERTILIDADE DO SOLO, 1., Piracicaba, 1986. Anais. Campinas, Fundação Cargill, 1986. p.43-52.

ROSOLEM, C.A.; MACHADO, J.K.; BRINHOLI, O. Efeito das relações $\mathrm{Ca} / \mathrm{Mg}$, $\mathrm{Ca} / \mathrm{K}$ e $\mathrm{Mg} / \mathrm{K}$ do solo na produção de sorgo sacarino. Pesquisa Agropecuária Brasileira, Brasília, 19(12):1443-8, dez. 1984.

ROSSI, N.; NYE, P.H.; GRUNES, D.L.; SANCHIRINO, C.A. Prediction of the calcium to calcium plus magnesium ratio in soil-grown winter wheat forage. Soil Science Society of America Journal, Madison, 52(1):152-60, Jan./Fev. 1988. 
SANIK JR, J.; PERKINS, A.; SCRENK, W.C. The effect of the calcium-magnesium ratio in the solubility and availability of plants nutrients. Soil Science Society of America Proceedings, Madison, 16(3):263-7, July/Aug. 1952.

SARRUGE, J.R. \& HAAG, H.P. Análises químicas em plantas. Piracicaba, ESALQ, 1974. 55p.

SFREDO, G.M. Efeito das relações entre $\mathrm{Ca}$ e $\mathrm{Mg}$ sobre o $\mathrm{pH}, \mathrm{Al}, \mathrm{Ca}$ e $\mathrm{Mg}$ no solo e sobre a produção de matéria seca do sorgo (Sorghum bicolor (L.) Moench). Viçosa, 1976. 61p. (Mestrado - Universidade Federal de Viçosa).

SHERCHAND, K. \& WHITNEY, O. Response to lime and P by several genetic sources of corn (Zea mays L.) on a low pH and P soil in the greenhouse. Journal of Plant Nutrition, New York, 8(11):1075-88, Nov. 1985.

SHOEMAKER, H.E.; McLEAN, E.O.; PRATT, P.F. Buffer methods for determining lime requirement of soil with appreciable amount of exchangeable aluminum. Soil Science Society of America Proceedings, Madison, 25:274-7, Jan./Feb. 1961.

SILVA, D.J. Necessidade de calagem para a produção de mudas de eucalipto. Viçosa, 1986. 53p. (Mestrado - Universidade Federal de Viçosa). 
SILVA, J.E. Balanço do cálcio e magnésio e desenvolvimento de milho em solos sob cerrado. Pesquisa Agropecuária Brasileira, Brasília, 15(3):329-33, July 1980.

SILVA, J.E. \& RITCHEY, K.D. Adubação potássica em solos do cerrado. In: SIMPÓSIO SOBRE POTASSIO NA AGRICULTURA BRASILEIRA, Londrina, 1982. Anais. Piracicaba, Instituto Internacional da Potassa; Instituto da Potassa e Fosfato; IAPAR, 1982. p.323-38.

SIMARD, R.R.; BATES, T.E.; EVANS, L.J. Effects of $\mathrm{CaCO}_{3}$ and $\mathrm{P}$ additions on corn (Zea mays L.) growth and nutrient availability in a Podzolic soil. Canadian Journal of Soil Science, Ottawa, 68(3):507-17, Aug. 1988.

SIQUEIRA, O.J.F.; BORKERT, C.M.; KOCHANN, R.A.; BARTZ, H.R.; RAMOS, M. Resposta do trigo à calagem, cultivado em sucessão com soja, em solos ácidos com diferentes teores de alumínio trocável em altos níveis de fertilidade. In: REUNIÃO ANUAL DE PESQUISA DE TRIGO, 7., Passo Fundo, 1975. Passo Fundo, EMBRAPA/CNPT, 1975. p.18-50.

SMITH, C.B. Sweet corn growth responses of leaf concentrations as affected by lime types and fertilizer treatments in a five year study. Journal of the American Society for Horticultural Science, Alexandria, 109(4):572-7, July 1984. 
SOARES, E. Influência da relação entre teores trocáveis de cálcio e magnésio do solo na absorção de potássio pelo centeio (Secale cereale L.). Piracicaba, 1975. 73p. (Mestrado - Escola Superior de Agricultura "Luiz de Queiroz"/USP).

SOARES, E.; LIMA, L.A. de; MISCHAN, M.M.; MELLO, F.A.F. de; BOARETTO, A.E. Efeito da adubação potássica na absorção do $\mathrm{K}, \mathrm{Ca}$ e $\mathrm{Mg}$ por plantas de soja. Revista de Agricultura, Piracicaba, 58(3):147-57, out. 1983.

SOUZA, D.M.G.; CARVALHO, L.J.C.; MIRANDA, L.N. Correção da acidez do solo. In: GOEDERT, J.W. ed. Solos dos cerrados; tecnologias e estratégias de manejo. São Paulo, Nobel; Brasília, EMBRAPA/Centro de Pesquisa Agropecuária dos Cerrados, 1985. p.99-127.

TISDALE, S.L.; NELSON, W.L.; BEATON, J.D. Soil fertility and fertilizers. 4.ed. New York, MacMilan Publ., 1985. 754p.

USHERWOOD, N.R. Interação de potássio com outros íons. In: SIMPÓSIO SOBRE POTÁSSIO NA AGRICULTURA BRASILEIRA, 1., Londrina, 1982. Anais. Piracicaba, Instituto da Potassa \& Fosfato; Instituto Internacional da Potassa, p.227-42. 
VASCONCELLOS, C.A.; SANTOS, H.L.; BAHIA FILHO, A.F.C.; OLIVEIRA, A.C.; PACHECO, E.B. Amostragem do solo em área com adubação fosfatada aplicada a lanço e no sulco de plantio. Revista Brasileira de Ciência do Solo, Campinas, 6(3):221-5, set./dez. 1982.

VOLKWEISS, S.J. Otimização das características da planta para maximizar a eficiência do adubo. In: SEMINÁRIO FÓSFORO, CÁLCIO, MAGNÉSIO, ENXOFRE E MICRONUTRIENTES: SITUAÇÃO ATUAL E PERSPECTIVAS NA AGRICULTURA, São Paulo, 1984. Anais. São Paulo, MANAH, 1986. p.8-21.

WELCH, L.F.; MULVANEY, D.L.; BOONE, L.V.; Mc KIBBEN, G.E.; PENDLETON, J.M. Relative efficiency of broadcast versus banded phosphorus for corn. Agronomy Journal, Madison, 58(3):283-7, May/June 1966. 
123

APÊNDICE 


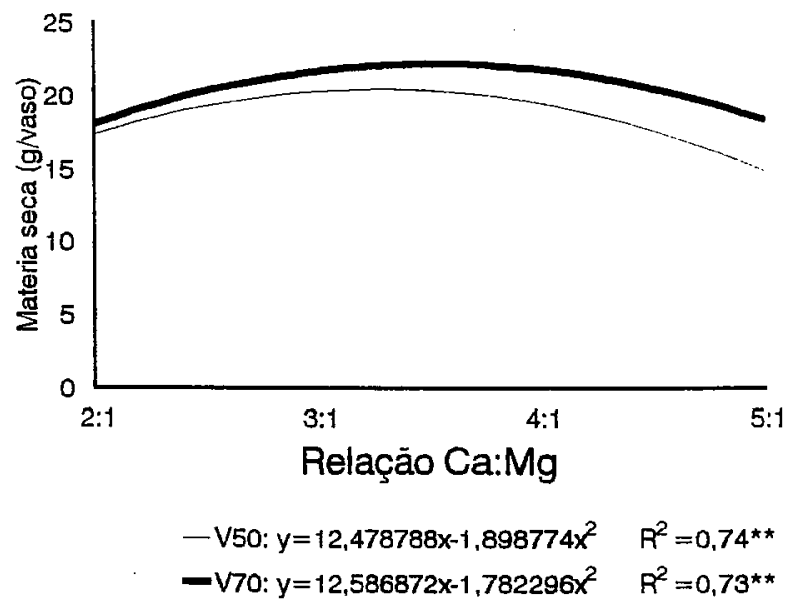

Figura 1 - Peso seco da parte aérea das plantas do milho em função das relações Ca:Mg no solo e das saturações por bases.

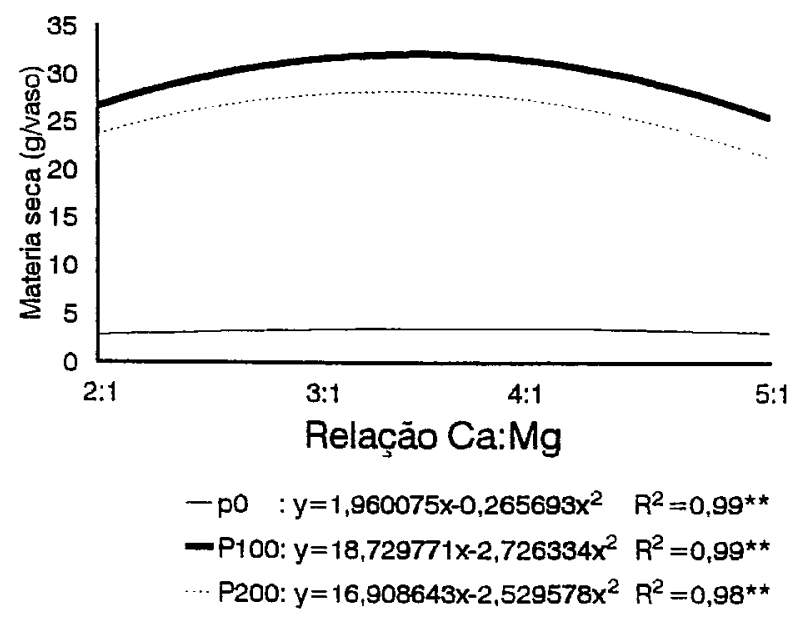

Figura 2 - Peso seco da parte aérea das plantas do milho em função das relações Ca:Mg no solo e das doses de $\mathrm{P}$ aplicadas. 


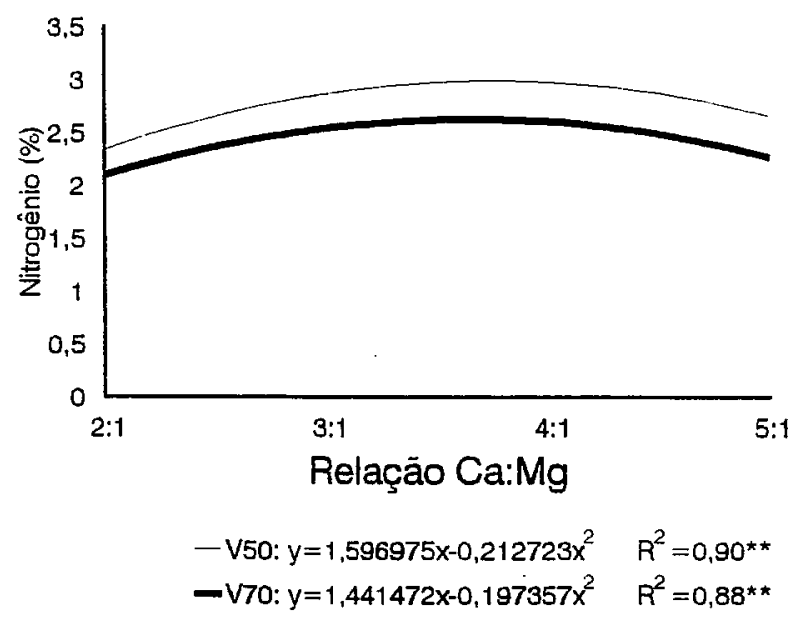

Figura 3 - Teor de $\mathbf{N}$ na matéria seca da parte aérea das plantas em função das relações Ca:Mg no solo e das saturações por bases.

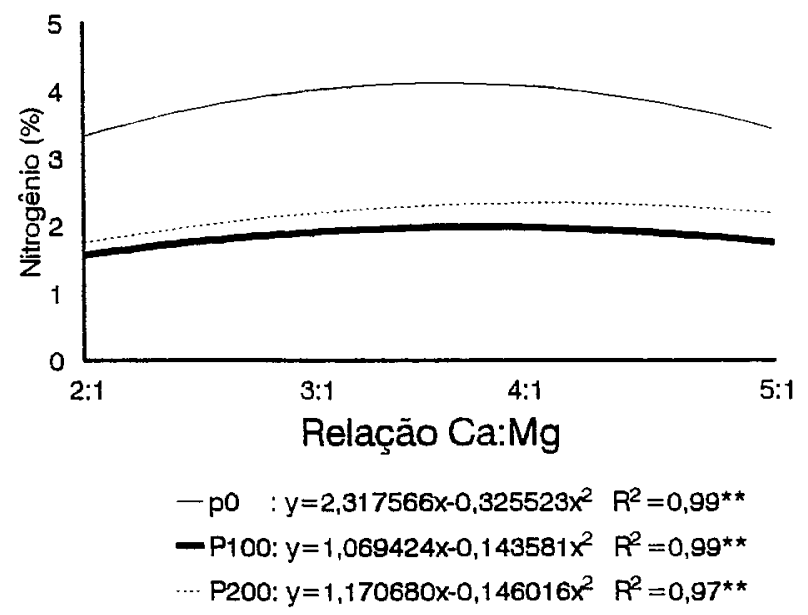

Figura 4 - Teor de N na matéria seca da parte aérea das plantas em função das relações Ca:Mg no solo e das doses de $\mathrm{P}$ aplicadas. 


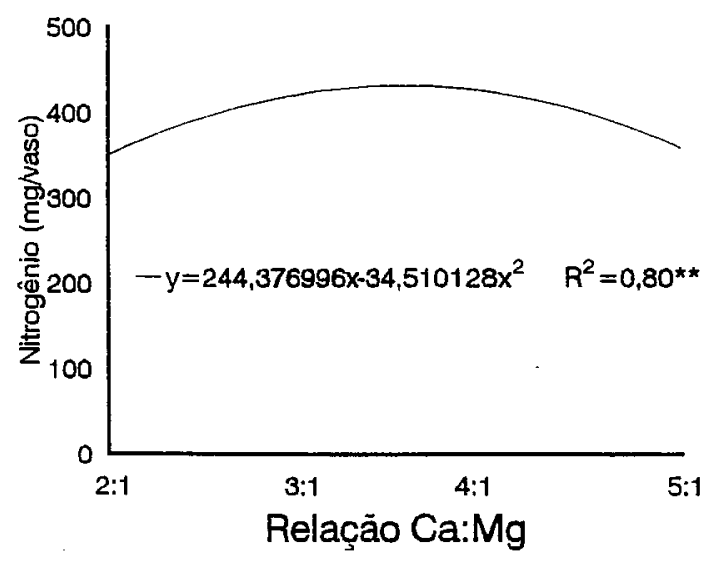

Figura 5 - Acúmulo de $\mathrm{N}$ na parte aérea das plantas em função das relações Ca:Mg no solo.

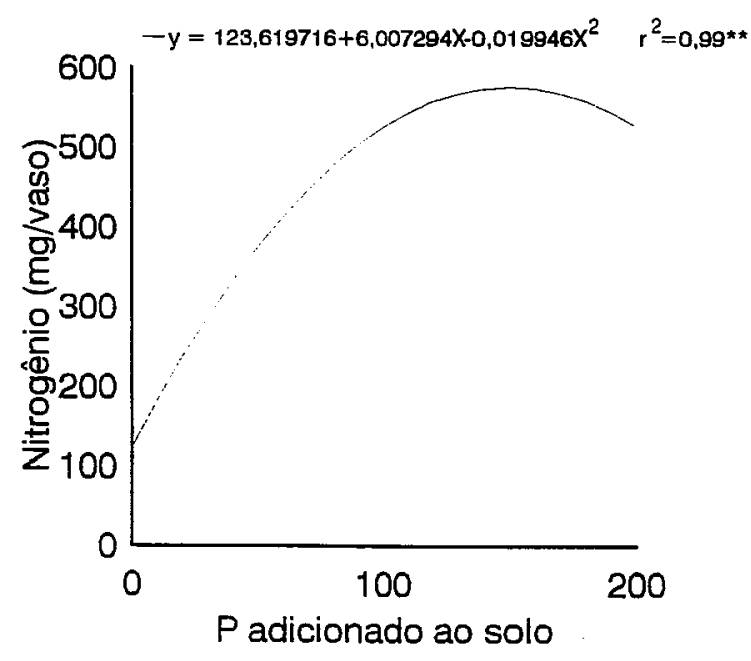

Figura 6 - Acúmulo de $\mathrm{N}$ na parte aérea das plantas em função das doses de $\mathrm{P}$ aplicados no solo. 


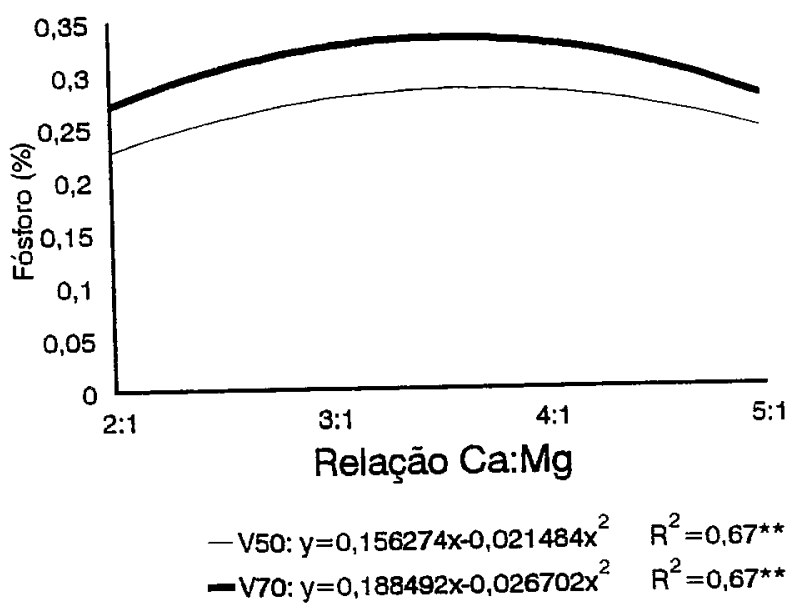

Figura 7 - Teor de P na matéria seca da parte aérea das plantas em função das relações Ca:Mg no solo e das saturações por bases.

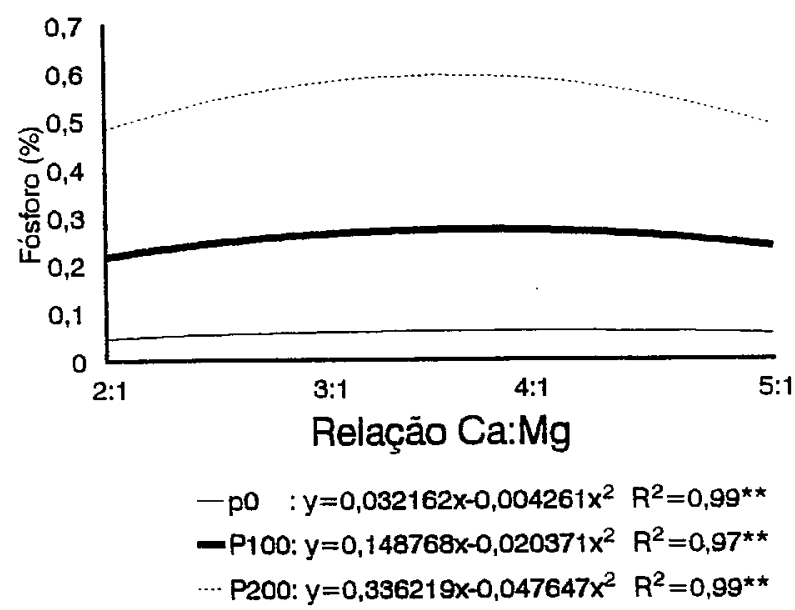

Figura 8 - Teor de P na matéria seca da parte aérea das plantas em função das relações Ca: $\mathrm{Mg}$ no solo e das doses de P aplicadas. 


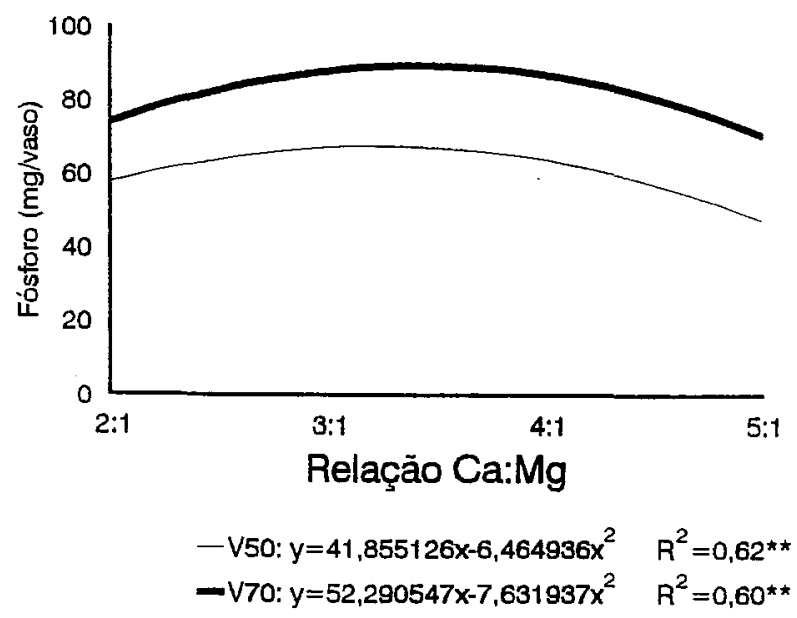

Figura 9 - Acúmulo de $\mathrm{P}$ na parte aérea das plantas em função das relações $\mathrm{Ca}: \mathrm{Mg}$ no solo e das saturações por bases.

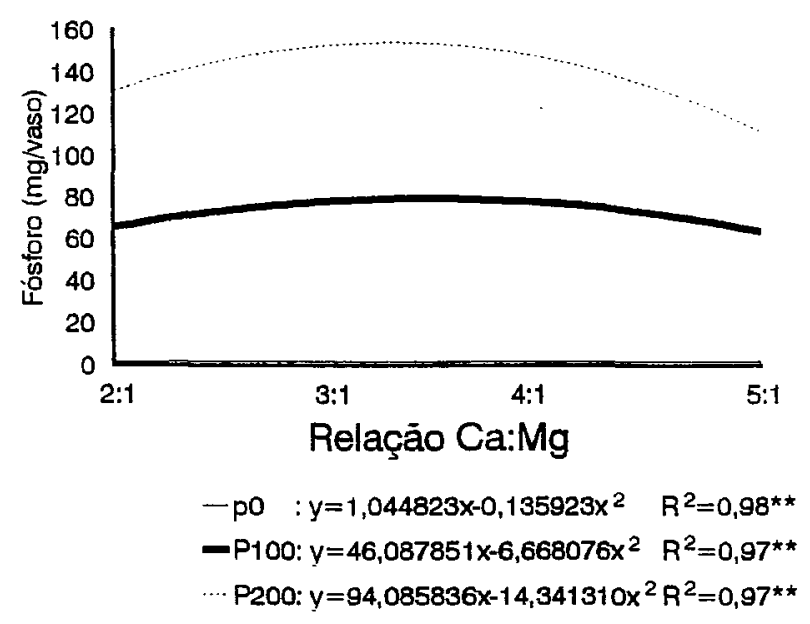

Figura 10 - Acúmulo de P na parte aérea das plantas em função das relações Ca:Mg no solos e das doses de $\mathrm{P}$ aplicadas. 


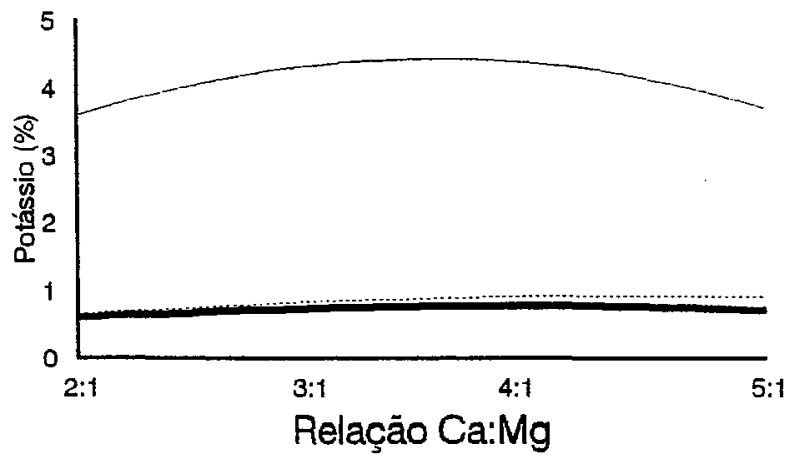

- po : $y=2,493920 x-0,350245 x^{2} \quad R^{2}=0,98^{\star \star}$

-P100: $y=0,399788 x-0,051357 x^{2} \quad R^{2}=0,97^{\star \star}$

... P200: $y=0,420860 x-0,047963 x^{2} \quad R^{2}=0,98^{\star *}$

Figura 11 - Teor de $\mathrm{K}$ na matéria seca da parte aérea das plantas em função das relações $\mathrm{Ca}: \mathrm{Mg}$ no solo e das doses de $\mathbf{P}$ aplicadas.

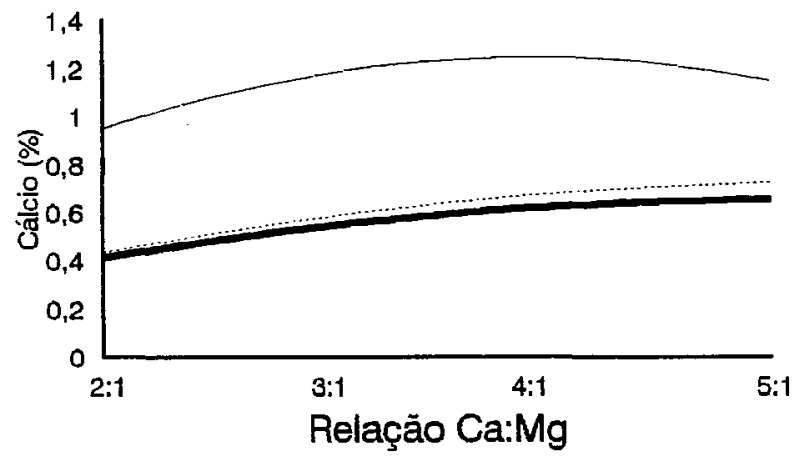

$$
\begin{array}{ll}
\text {-po: } y=0,637948 x-0,081571 x^{2} & R^{2}=0,96^{\star \star} \\
\text {-P100: } y=0,255672 x-0,024890 x^{2} & R^{2}=0,99^{\star \star} \\
\text { ‥ P200: } y=0,267146 x-0,024324 x^{2} & R^{2}=0,99^{\star \star}
\end{array}
$$

Figura 12 - Teor de Ca na matéria seca da parte aérea das plantas em função das relações Ca:Mg no solo e das doses de $\mathbf{P}$ aplicadas. 


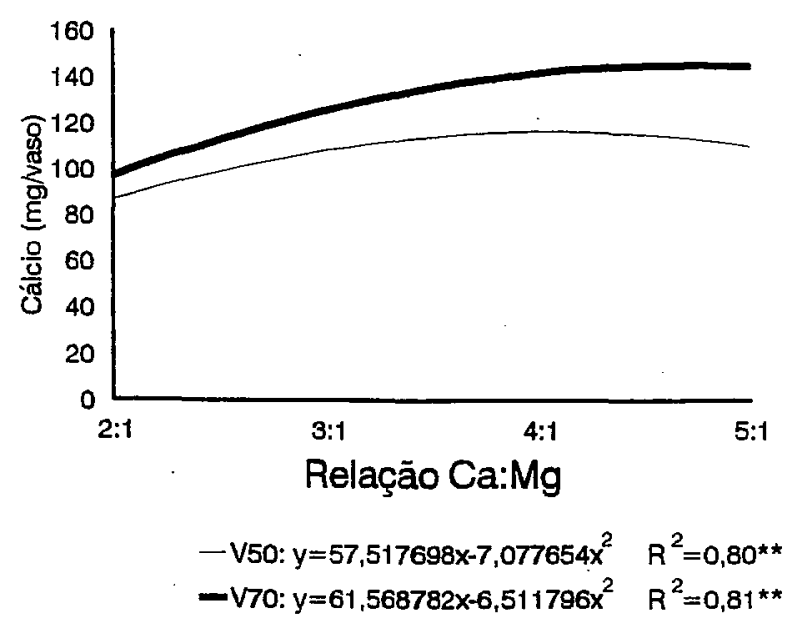

Figura 13 - Acúmulo de Ca na parte aérea das plantas em função das relações Ca:Mg no solo e das saturações por bases.

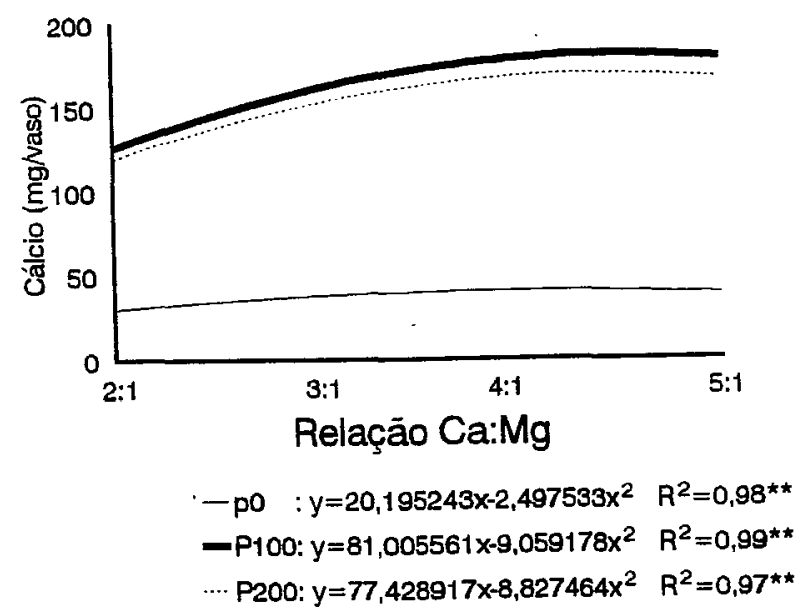

Figura 14 - Acúmulo de Ca na parte aérea das plantas em função das relações Ca:Mg no solo e das doses de $\mathrm{P}$ aplicadas. 


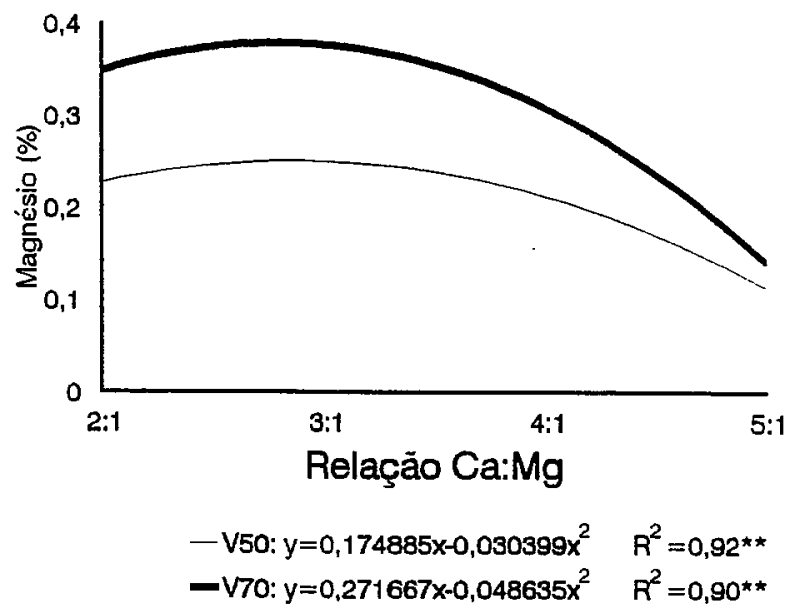

Figura 15 - Teor de Mg na matéria seca da parte aérea das plantas em função das relações Ca:Mg no solo e das saturações por bases.

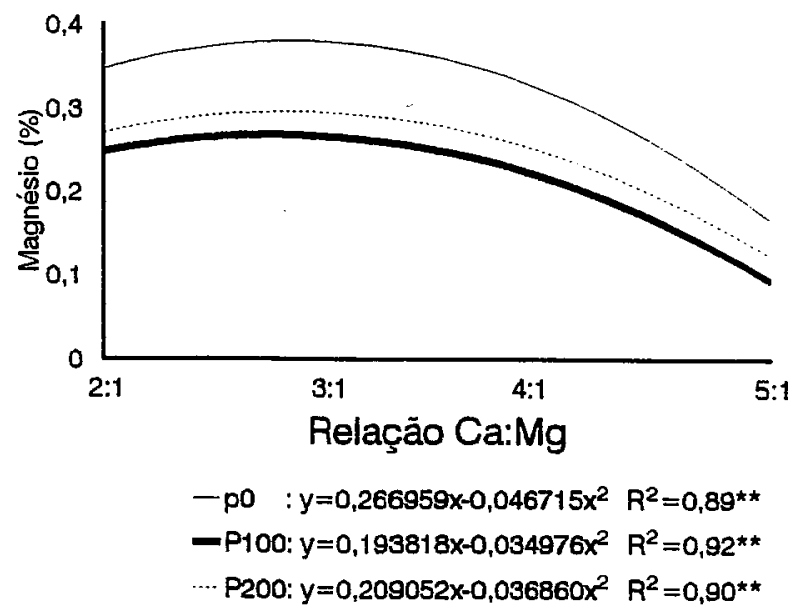

Figura 16 - Teor de Mg na matéria seca da parte aérea das plantas em função das relações Ca: $\mathrm{Mg}$ no solo e das doses de $\mathrm{P}$ aplicadas. 


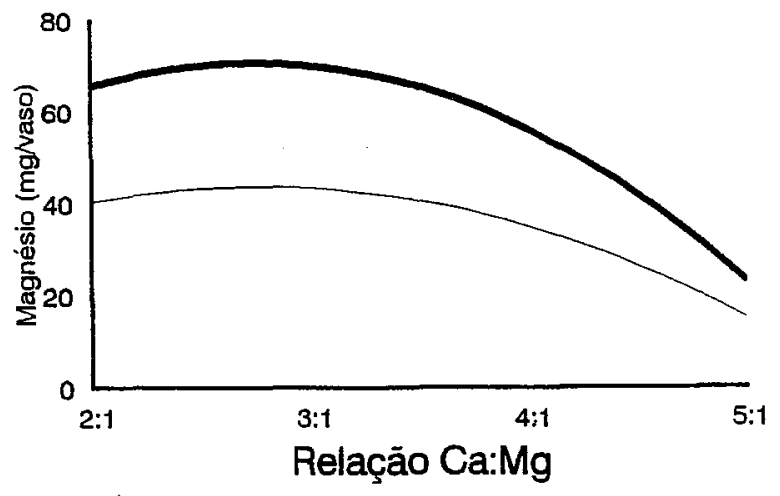

-V50: $y=31,723839 x-5,735833 x^{2} \quad R^{2}=0,73^{\star \star}$

-V70: $y=51,503454 x-9,369091 x^{2} \quad R^{2}=0,72^{\star *}$

Figura 17 - Acúmulo de Mg na parte aérea das plantas em função das relações Ca:Mg no solo e das saturações por bases.

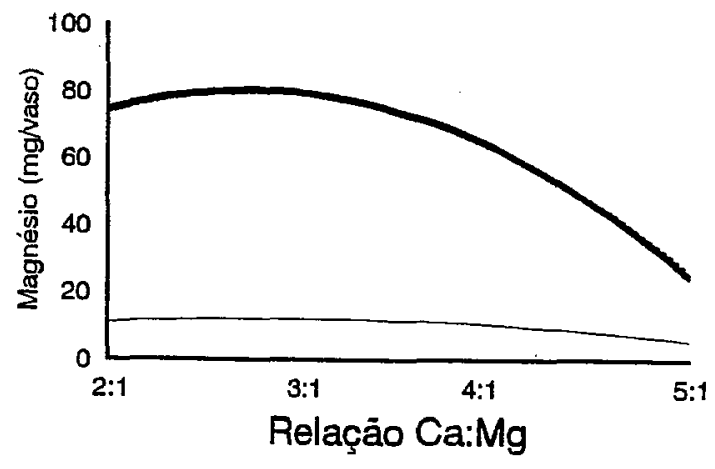

$$
\begin{array}{ll}
\text {-po : } y=8,460785 x-1,462352 x^{2} & R^{2}=0,93^{\star \star} \\
\text {-P100: } y=58,723532 x-10,737374 x^{2} & R^{2}=0,91^{\star \star} \\
\text { ‥ P200: } y=57,656623 x-10,457660 x^{2} & R^{2}=0,88^{\star \star}
\end{array}
$$

Figura 18 - Acúmulo de $\mathrm{Mg}$ na parte aérea das plantas em função das relações Ca:Mg no solo e das doses de $P$ aplicadas. 


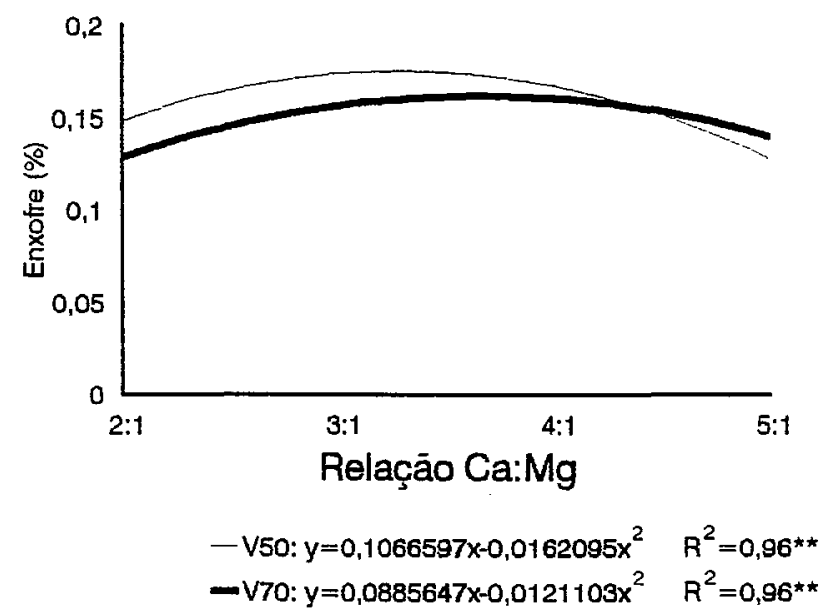

Figura 19 - Teor de $\mathbf{S}$ na matéria seca da parte aérea das plantas em função das relações Ca:Mg no solo e das saturações por bases.

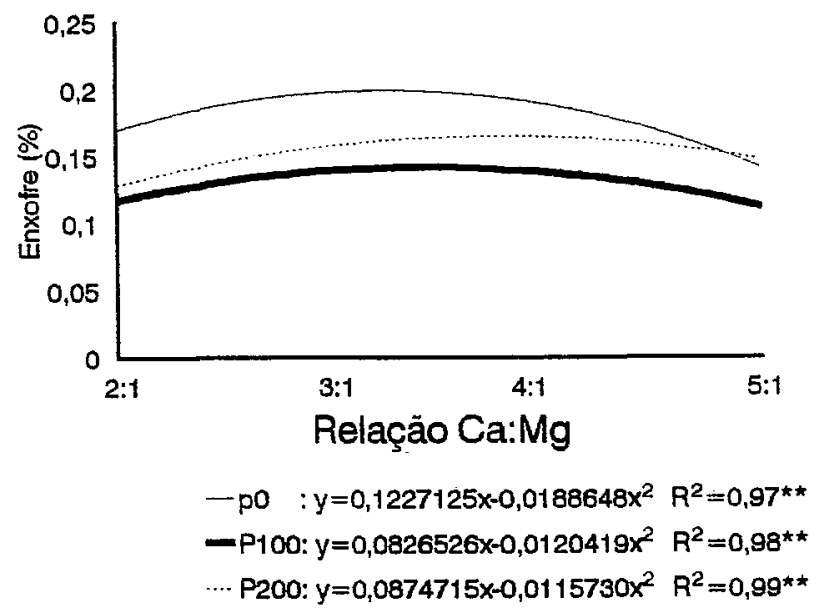

Figura 20 - Teor de $S$ na matéria seca da parte aérea das plantas em função das relações Ca:Mg no solo e das doses de $\mathrm{P}$ aplicadas. 


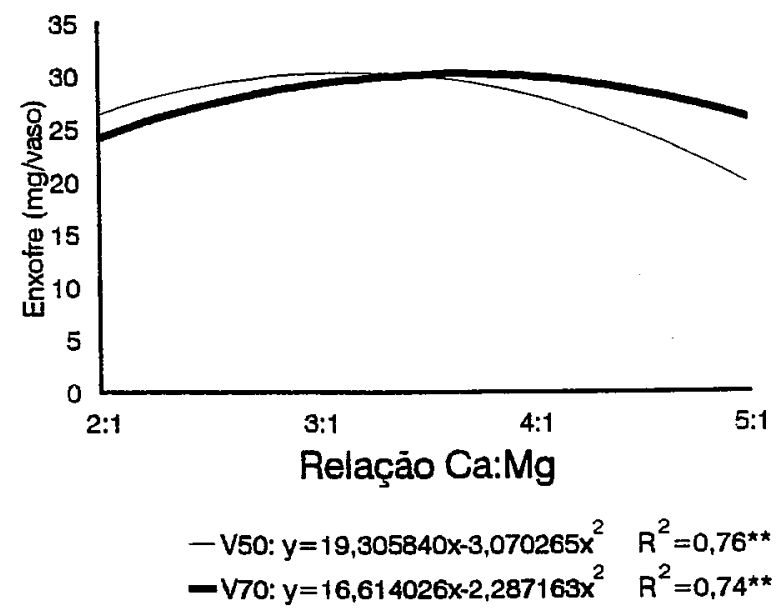

Figura 21 - Acúmulo de $\mathrm{S}$ na parte aérea das plantas em função das relações $\mathrm{Ca}: \mathrm{Mg}$ no solo e das saturações por bases.

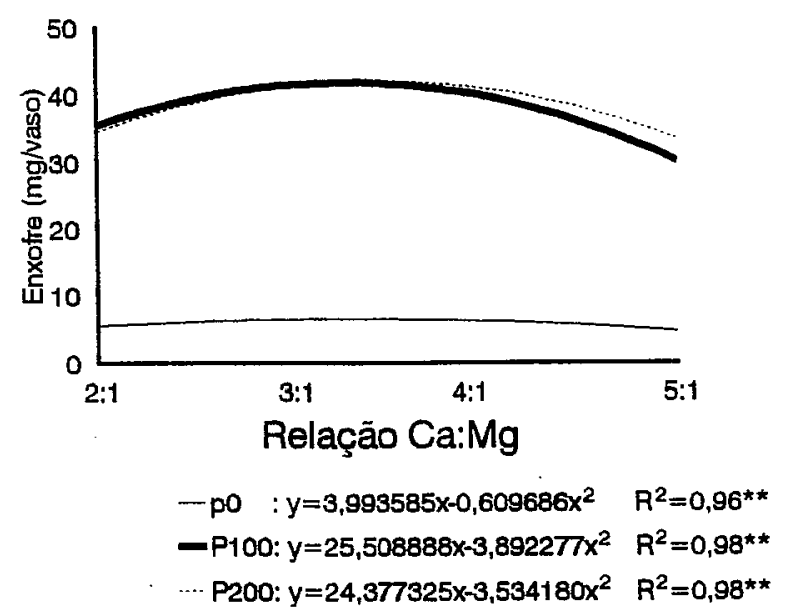

Figura 22 - Acúmulo de $\mathrm{S}$ na parte aérea das plantas em função das relações $\mathrm{Ca}: \mathrm{Mg}$ no solo e das doses de $\mathbf{P}$ aplicadas. 